\title{
LUCIANO LAGATTA
}

Impacto socioeconômico das políticas sanitárias sobre os estabelecimentos avícolas comerciais de postura da regional agropecuária de Limeira, Estado de São Paulo

\section{Pirassununga}




\section{LUCIANO LAGATTA}

Impacto socioeconômico das políticas sanitárias sobre os estabelecimentos avícolas comerciais de postura da regional agropecuária de Limeira, Estado de São Paulo

Dissertação apresentada ao Programa de Pós-Graduação em Nutrição e Produção Animal da Faculdade de Medicina Veterinária e Zootecnia da Universidade de São Paulo para obtenção do título de Mestre em Ciências.

Departamento:

Nutrição e Produção Animal

Área de concentração:

Nutrição e Produção Animal

Orientador:

Prof. Dr. Augusto Hauber Gameiro

\section{Pirassununga}


Autorizo a reprodução parcial ou total desta obra, para fins acadêmicos, desde que citada a fonte.

DADOS INTERNACIONAIS DE CATALOGAÇÃO-NA-PUBLICAÇÃO

(Biblioteca Virginie Buff D’Ápice da Faculdade de Medicina Veterinária e Zootecnia da Universidade de São Paulo)

Lagatta, Luciano

Impacto socioeconômico das políticas sanitárias sobre os estabelecimentos avícolas comerciais de postura da regional agropecuária de Limeira, Estado de São Paulo / Luciano Lagatta. -- 2014.

99 f. : il.

Dissertação (Mestrado) - Universidade de São Paulo. Faculdade de Medicina Veterinária e Zootecnia. Departamento de Nutrição e Produção Animal, Pirassununga, 2014.

Programa de Pós-Graduação: Nutrição e Produção Animal.

Área de concentração: Nutrição e Produção Animal.

Orientador: Prof. Dr. Augusto Hauber Gameiro.

1. Avicultura. 2. Biosseguridade. 3. Custo de produção. 4. Legislação. 5. Postura comercial. I. Título. 


\section{ERRATA}

LAGATTA, L. Impacto socioeconômico das políticas sanitárias sobre os estabelecimentos avícolas comerciais de postura da regional agropecuária de Limeira, Estado de São Paulo. 2014. 99 f. Dissertação (Mestrado em Ciências) - Faculdade de Medicina Veterinária e Zootecnia, Universidade de São Paulo, Pirassununga, 2014

\section{Página}

$$
\text { Ficha }
$$

catalográfica
Onde se lê

99 f. il.
Leia-se

99 f.: il.; 1 CD_ROM 


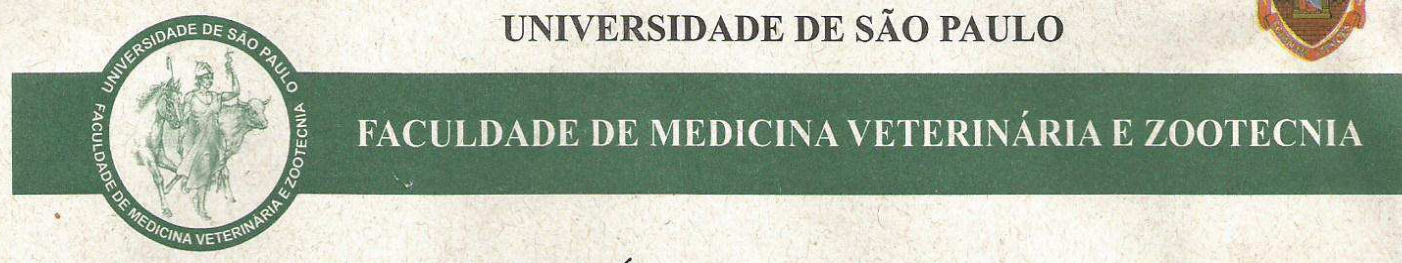

Comissão de Ética no Uso de Animais

\section{CERTIFICADO}

Certificamos que o Projeto intitulado "Impacto socioeconômico da política sanitária avícola nas granjas de postura comercial da regional agrícola de Limeira", protocolado sob o $\mathrm{n}^{\circ} 3005 / 2013$, não utilizando animais, sob a responsabilidade do(a) Prof. Dr. Augusto Hauber Gameiro, foi aprovado em reunião de 26/6/2013 e está de acordo com os princípios éticos de experimentação animal da Comissão de Ética no Usó de Animais da Faculdade de Medicina Veterinária e Zootecnia da Universidade de São Paulo.

We certify that the Research "Socio-economic impact of avian health policy in Limeira agricultural region for layer hens farm", protocol number 3005/2013, not using animals, under the responsibility Prof. Dr. Augusto Hauber Gameiro, was approved in the meeting of day 6/26/2013 and agree with Ethical Principles in Animal Research adopted by Ethic Committee in the Use of Animals of the School of Veterinary Medicine and Animal Science of University of São Paulo.

São Paulo, 27 de junho de 2013.

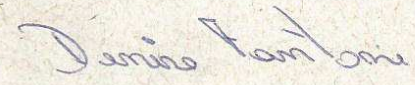

Denise Tabacchi Fantoni

Presidente 


\section{FOLHA DE AVALIAÇÃO}

Nome: LAGATTA, Luciano.

Título: Impacto socioeconômico das políticas sanitárias sobre os estabelecimentos avícolas comerciais de postura da regional agropecuária de Limeira, Estado de São Paulo.

Dissertação apresentada ao Programa de PósGraduação em Nutrição e Produção Animal da Faculdade de Medicina Veterinária e Zootecnia da Universidade de São Paulo para obtenção do título de Mestre em Ciências.

Data:

1

\section{Banca Examinadora}

Prof. Dr.:

Instituição: Julgamento:

Prof. Dr.:

Instituição: Julgamento:

Prof. Dr.:

Instituição: Julgamento: 


\section{DEDICATÓRIA}

À minha esposa, Paula, com amor, admiração e gratidão por sua compreensão, carinho, presença e incansável apoio. Aos meus pais, Marizilda e Tadeu, pelos anos dedicados aos meus cuidados e à minha formação. Ao meu irmão, Leandro e aos amigos, "Formol" e "NanoF", grandes companheiros. Dedico ainda ao meu filho, Leonardo, deixando-lhe o legado do saber e do conhecimento para edificação pessoal, profissional e espiritual. E, à Fifi companheira nos momentos de digitação.

\section{AGRADECIMENTOS}

À Deus e aos mentores espirituais.

Ao Prof. Dr. Augusto Hauber Gameiro, pela atenção, paciência e apoio durante o processo de orientação, que nos meses de convivência, muito me ensinou, contribuindo para meu crescimento científico, intelectual, profissional e pessoal.

À Faculdade de Medicina Veterinária e Zootecnia da Universidade de São Paulo e ao Departamento de Nutrição e Produção Animal - VNP, pela oportunidade de realização do curso de mestrado e a todos os docentes e colegas, em especial a Camila e a Thayla.

À Coordenadoria de Defesa Agropecuária do Estado de São Paulo, pelo apoio para a realização do mestrado, em especial ao $\mathrm{Eng}^{\circ} \mathrm{Agr}^{\circ}$ Antonio Carlos Junqueira do Val Filho, Diretor do Escritório de Defesa Agropecuária de Limeira, M.V. Dr. Heinz Otto Hellwig, Coordenador da Defesa Agropecuária e Eng ${ }^{a}$ Agr $^{\text {a }}$ Mônika Bergamaschi, Secretária da Agricultura do Estado de São Paulo e, aos demais colegas da instituição.

Aos colegas, Médicos Veterinários, Bruno Deponti e Eduardo Capodifoglio e, principalmente, a todos os produtores de ovos da regional agropecuária de Limeira, por terem colaborado de maneira significativa para conclusão deste trabalho. 
DA VIDA

"Moralistas são pessoas que renunciam às alegrias corriqueiras para poder, sem culpa e recriminação, estragar a alegria dos outros." Bertrand Russell

"Para quê levar a vida tão a sério, se a vida é uma alucinante aventura da qual jamais sairemos

vivos."

Bob Marley

"A vida é uma peça de teatro que não permite ensaios. Por isso, cante, chore, dance, ria e viva intensamente, antes que a cortina se feche e a peça termine sem aplausos."

Charles Chaplin

"Se você acabar com uma vida tediosa e miserável porque você ouviu seus pais, seus professores, seu padre ou alguma pessoa na televisão, dizendo para você como conduzir a sua vida, então a culpa é só sua e você merece."

Frank Zappa

"O que se leva desta vida é a vida que se leva." Barão de Itararé 


\section{RESUMO}

LAGATTA, L. Impacto socioeconômico das políticas sanitárias sobre os estabelecimentos avícolas comerciais de postura da regional agropecuária de Limeira, Estado de São Paulo. [Socio-Economic Impact of Health Policies on Egg Farms in Limeira Region, São Paulo State]. 2014. 99 f. Dissertação (Mestrado em Ciências) - Faculdade de Medicina Veterinária e Zootecnia, Universidade de São Paulo, Pirassununga, 2014.

É reconhecida a importância da avicultura para o agronegócio e para o desenvolvimento do Brasil. Mas o País tem enfrentado grande concorrência internacional, que se traduz em barreiras sanitárias e exigências cada vez maiores de controle de seu rebanho por parte dos importadores. Neste sentido, o Ministério da Agricultura, Pecuária e Abastecimento (MAPA) publicou uma série de atos legais para viabilizar a organização dos programas de saúde animal, entre eles as Instruções Normativas $n^{\circ}$ 56/2007, $n^{\circ}$ 59/2009, n³6/2012 e n¹0/2013, para estabelecer os procedimentos para registro e fiscalização de estabelecimentos avícolas comerciais e de reprodução, voltados à biosseguridade do sistema avícola. Como todos os setores produtivos, a avicultura é fortemente influenciada pela sua estrutura de custos, de modo que há um certo sentimento de que a adequação às medidas de biosseguridade, preconizadas pelas normativas, pode impactar a atividade de produção de ovos comerciais de modo a levar, eventualmente, alguns avicultores ao abandono da mesma. O objetivo deste trabalho foi analisar o impacto socioeconômico das políticas sanitárias para estabelecimentos avícolas comerciais de postura da regional agropecuária de Limeira, Estado de São Paulo, analisando o perfil socioeconômico da propriedade e do produtor e, estimando o custo de produção e seu impacto em atendimento às medidas de biosseguridade preconizadas pelas normativas. Para a análise do perfil das propriedades foram utilizados os dados dos 28 estabelecimentos avícolas, levantados por meio de documentação para registro. Para a análise do perfil do produtor e para estimar os custos de produção foram considerados dez estabelecimentos, voluntários à pesquisa, visitados entre os meses de junho e julho de 2013. O resultado do estudo sugere que as adequações à biosseguridade podem ser factíveis de serem realizadas economicamente, sendo o custo relativamente pequeno frente aos possíveis riscos de enfermidades, representando entre $1,61 \%$ e $2,09 \%$ do custo total 
de produção. No entanto, as sucessivas alterações nas legislações podem fazer com que o programa de sanidade avícola perca a credibilidade diante da sociedade e dos produtores que demonstram resistência às mudanças nos paradigmas zoosanitários.

Palavras-chave: Avicultura. Biosseguridade. Custo de produção. Legislação. Postura comercial. 


\section{ABSTRACT}

LAGATTA, L. Socio-Economic Impact of Health Policies on Egg Farms in Limeira Region, São Paulo State. [Impacto socioeconômico das políticas sanitárias sobre os estabelecimentos avícolas comerciais de postura da regional agropecuária de Limeira, Estado de São Paulo]. 2014. 99 f. Dissertação (Mestrado em Ciências) Faculdade de Medicina Veterinária e Zootecnia, Universidade de São Paulo, Pirassununga, 2014.

The importance of the poultry industry for agribusiness and development is recognized in Brazil, but the country has faced strong international competition, translated into sanitary barriers and increasing requests for the control of Brazilian flock by importers. In this regard, the Ministry of Agriculture, Livestock and Supply (MAPA) has published a series of legal acts to facilitate the organization of animal health programs, including Regulatory Instructions n56/2007, n59/2009, n`36/2012 $\& n^{\circ} 10 / 2013$, to establish procedures for the registration and inspection of boilers, layer hens and commercial poultry breeding, focused on biosecurity systems. Like all productive sectors, the poultry one is strongly influenced by its cost structure, thus some people believe that the adequacy of biosecurity measures could affect the activity of commercial egg production and, eventually, lead some producers to the abandonment of the activity. The aim of this study was to analyze the socioeconomic impact of health policies on farm eggs of Limeira regional, Sao Paulo State, by analyzing the socioeconomic profile of the property and the producer, estimating the cost of production and its impact on compliance with biosecurity measures recommended by the Regulatory Instructions. For the analysis of the profile of farms we used data of twenty-eight poultry establishments, raised through documentation register. For the analysis of the profile of the producer and to estimate the costs of production, data was raised in ten farm eggs, volunteers of this research, which were visited between June and July 2013. The result of the study suggests that adaptations to biosecurity are economically feasible and costs are relatively small compared to the potential risks of disease, representing between $1.61 \%$ and $2.09 \%$ of the total production cost, thus not justifying the abandonment of activity. Nevertheless, successive changes in legislation may lead poultry health programs to 
lose credibility in society and with producers who demonstrate resistance to changes in zoo-sanitary paradigms.

Keywords: Biosecurity. Farm eggs. Legislation. Poultry. Production cost. 


\section{SUMÁRIO}

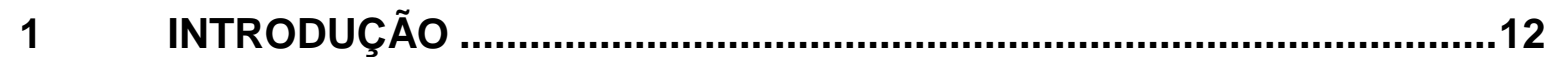

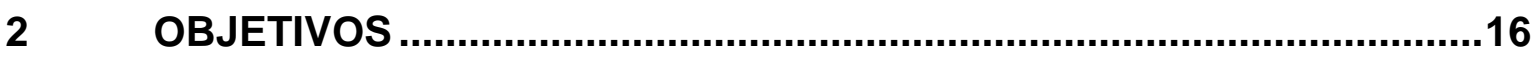

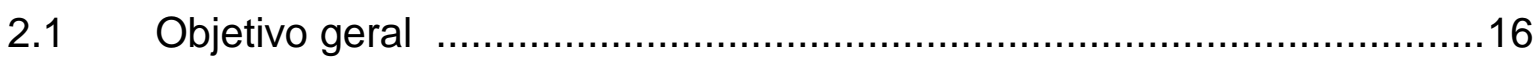

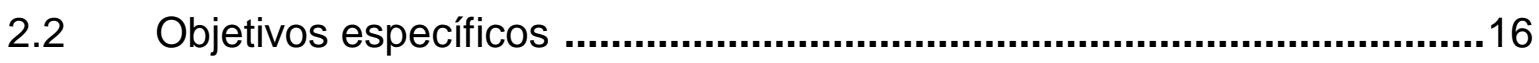

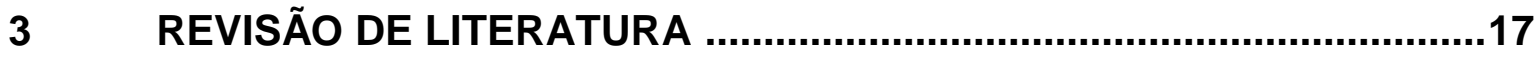

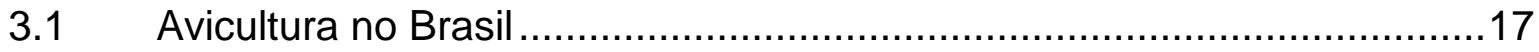

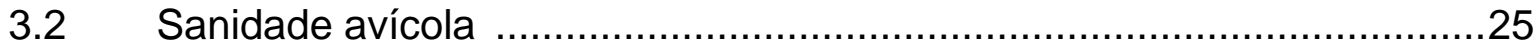

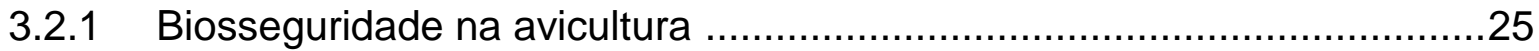

3.2.2 Principais enfermidades sob vigilância na avicultura ............................28

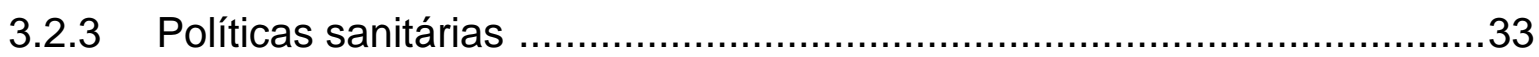

3.2.4 Registro de estabelecimento avícola coercial.....................................40

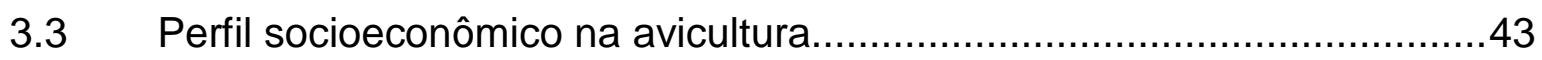

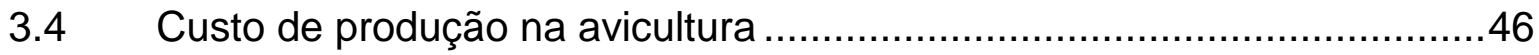

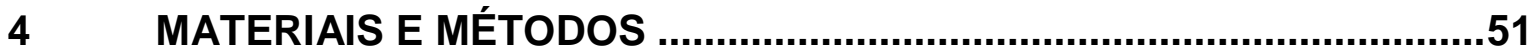

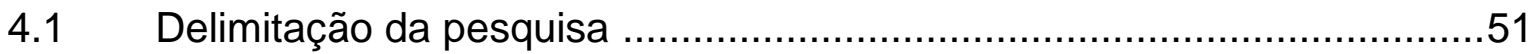

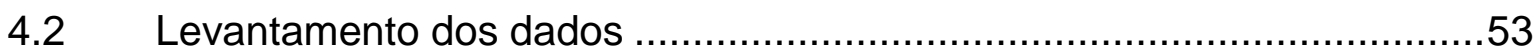

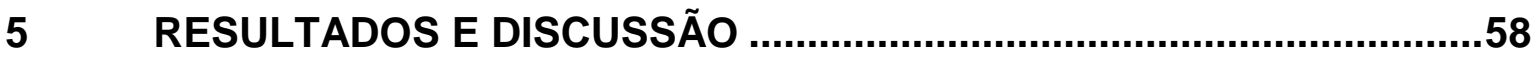

5.1 Análise do perfil dos estabelecimentos avícolas comerciais de postura da regional agropecuária de Limeira ........................................58

$5.2 \quad$ Análise do perfil socioeconômico do produtor ......................................61

5.3 Estimativa dos custos de produção de ovos..........................................63

5.4 Impactos das Instruções Normativas sobre os custos de produção de

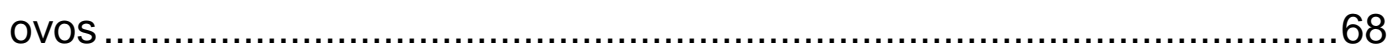

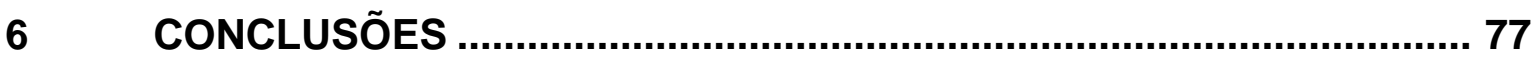

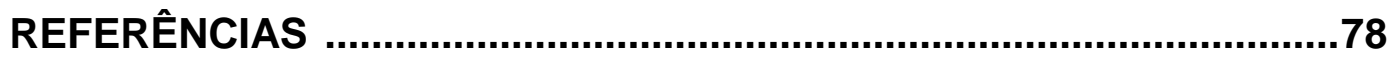

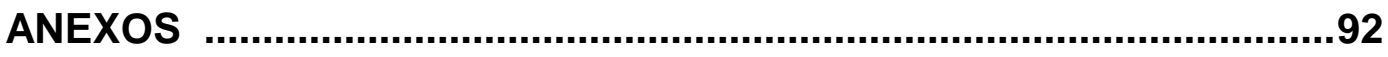




\section{INTRODUÇÃO}

De acordo com a Agência de Integração à Saúde, Meio Ambiente e Desenvolvimento Social do Brasil - Integra Brasil (2012), o País é um dos líderes mundiais na produção e exportação de diversos produtos agropecuários. O desenvolvimento científico, tecnológico e a modernização da atividade rural, obtidos por intermédio de pesquisas e da expansão da indústria de máquinas e insumos, contribuíram igualmente para transformar o País em uma das mais respeitáveis plataformas mundiais do agronegócio. Ainda de acordo com a Integra Brasil, (2012), a adoção de programas de sanidade animal e vegetal, garantindo a produção de alimentos saudáveis, também ajudou o País a alcançar essa condição.

Todavia, apesar do crescimento em produção e exportação de produtos agropecuários, o País tem enfrentado grande concorrência internacional, que se traduz em barreiras sanitárias e exigências cada vez maiores de controle de seu rebanho por parte dos importadores. A saúde animal, o melhoramento genético e a nutrição adequada constituem a base que serve de apoio ao desenvolvimento de qualquer sistema de produção animal. A higiene e o manejo zoossanitário fornecem, ao lado da genética, as condições de higidez necessária à criação animal, tornando a produção economicamente viável (DOMINGUES, 2008).

A avicultura, indiscutivelmente, é um dos componentes mais importantes do agronegócio nacional e internacional. O desenvolvimento da avicultura é o símbolo do crescimento e da modernização do agronegócio no Brasil. A avicultura é uma atividade econômica internacionalizada e relativamente uniforme, sem fronteiras geográficas de tecnologia. Pode ser considerada uma atividade que não deve ser analisada apenas sob o aspecto de produção e distribuição, e sim através de uma abordagem sistêmica (VIEIRA; DIAS, 2004).

Segundo o Ministério da Agricultura Pecuária e Abastecimento - Brasil (2013a), nas últimas três décadas, a avicultura brasileira têm apresentado altos índices de crescimento. Seu bem principal, o frango de corte, conquistou os mais exigentes mercados. O País se tornou o terceiro produtor mundial e líder em exportação. A parceria entre indústria e avicultores também contribuiu para a 
excelência técnica em todas as etapas da cadeia produtiva, resultando em reduzidos custos de transação e na qualidade, que atende às demandas de todo o mundo (BRASIL, 2013a).

De acordo com Brandalize (2013), as principais vantagens dos estabelecimentos avícolas brasileiros são operacionais e sanitárias. Os cuidados com que os profissionais e produtores brasileiros tratam de suas aves, tanto nos aspectos de manejo para obtenção de melhores resultados zootécnicos, quanto nos controles sanitários para a prevenção de enfermidades, com o status de livre de doenças de controle internacional, que podem trazer restrições comerciais ao País, garantindo maior produtividade, é o diferencial frente à avicultura mundial.

Para a Embrapa (2004), o mercado é complexo e competitivo, acompanhado pelo crescimento nos níveis de consciência e de cobrança dos consumidores, impulsionados pela ação esclarecedora e fiscalizadora de diversas entidades, sejam elas governamentais ou não. Valente et al. (2009) relataram que nos anos recentes, surtos de doenças infecciosas em animais, tais como Influenza Aviária ou "Gripe do Frango", Febre Aftosa e Encefalopatia Espongiforme Bovina, ou "Doença da Vaca Louca", têm influenciado o mercado, impedindo a comercialização de certos produtos de origem animal pelos países acometidos. Sendo assim, a uniformidade de padrões e comunicação aberta são cada vez mais importantes para a harmonia e promoção internacional do comércio de animais e seus produtos.

Segundo Domingues (2008), com o objetivo de informar a situação zoossanitária mundial e controlar o comércio entre países, foram criados dois organismos internacionais: a Organização Mundial de Saúde Animal (OIE) e a Organização Mundial do Comércio (OMC). A maioria dos países da América do Sul e do Norte são países membro da OIE e, portanto, concordam em fornecer qualquer informação que é necessária para minimizar a disseminação de enfermidades animais importantes. Países membros da OMC, no que se refere à sanidade, são solicitados a informarem os focos de doenças de notificação obrigatória à OIE.

De acordo com Revolledo e Ferreira (2009), a indústria avícola e os médicos veterinários atualmente enfrentam novos desafios que incluem emergência de novas doenças e reemergência das existentes, que causam grandes perdas econômicas, forte concorrência global, constantes aumentos nos custos de alimentação, mudanças nas condições sociais e políticas, assim como na percepção do consumidor e nas demandas quanto ao bem estar animal e à segurança alimentar. 
Ainda de acordo com Revolledo e Ferreira (2009), o impacto do risco de enfermidades, como a doença de Newcastle ou a Influenza Aviária, representa um perigo permanente em qualquer lugar do mundo, por sua patogenicidade e pela obrigatoriedade de se aplicarem sistemas de sacrifício. Tais enfermidades representam grandes perdas econômicas potenciais para a indústria avícola. $O$ desenvolvimento e o crescimento de muitos países dependem e dependerão de suas economias agrícolas e isso, por sua vez, se relaciona com o desempenho de seus serviços veterinários. Para assegurar a saúde animal é necessária a existência de serviços veterinários bem estruturados, capacitados e aptos para detecção e adoção precoce das medidas de controle e erradicação das enfermidades (BRASIL, 2009a).

Neste sentido, o Ministério da Agricultura, Pecuária e Abastecimento (MAPA) tem procurado ter uma atuação efetiva de incluir a atenção à sanidade animal de forma articulada entre os diversos níveis de governo. O MAPA expediu uma série de atos legais para viabilizar a organização de programas de sanidade animal. São Portarias, Instruções Normativas e de Serviços que regulamentam os programas, na perspectiva da atenção integral à sanidade animal. A Política Nacional de Defesa Agropecuária tem como propósito definir diretrizes e responsabilidades institucionais, com vistas a criar condições para proteger a saúde do rebanho nacional, bem como prevenir agravos à saúde pública. O serviço veterinário oficial, responsável pela condução da política de sanidade animal, compartilha com o setor privado as responsabilidades para aplicação das medidas que objetivam a melhoria da saúde animal (BRASIL, 2009a).

Sendo assim, em 19 de setembro de 1994, o MAPA por meio da Portaria Ministerial no 193 consolidou e estruturou o Programa Nacional de Sanidade Avícola (PNSA) (BRASIL, 1994). Em 04 de dezembro de 2007, publicou a Instrução Normativa (IN) $n^{\circ} 56$ para estabelecer os procedimentos de registro e fiscalização de estabelecimentos avícolas (BRASIL, 2007b). Em 02 de dezembro de 2009 o MAPA publica a Instrução Normativa $n^{\circ} 59$, alterando, entre outros dispositivos, padrões métricos e prazos fixados na IN 56. Atendendo, com isso, a reivindicação do setor, que não encontrou tempo hábil e condições, inclusive econômicas, para atender algumas das exigências prescritas na IN 56 de 2007 (BRASIL, 2009c).

No entanto, mais uma vez por solicitação do setor, o MAPA, publicou a IN n`36 em 06 de dezembro de 2012, alterando artigos e parágrafos da IN n 56 e n 
59. Em 11 de abril de 2013 foi publicada a IN $n^{\circ} 10$, na qual foi definido o programa de gestão de risco diferenciado para os estabelecimentos avícolas considerados de maior susceptibilidade à introdução e disseminação de enfermidades e para estabelecimentos avícolas que exerçam atividades que necessitam de maior rigor sanitário (BRASIL, 2013b).

Com a regulamentação dessa atividade produtiva seria possível intensificar as medidas para prevenção da ocorrência da Influenza Aviária no Brasil, assim como evitar outros possíveis problemas sanitários no plantel avícola no País. No entanto, são várias as modificações exigidas pelas normativas, além de transformações e/ou adequações técnicas recentes que a atividade requer para que se consiga obter sucesso na criação. Essas exigências podem resultar em mais despesas e dedicação por parte dos produtores. A situação causa preocupação ao setor em relação aos custos necessários para atender as referidas normas. Os custos elevados com a adequação das granjas às novas exigências do Ministério da Agricultura é uma das preocupações, especialmente, dos pequenos avicultores. Surgem problemas de dificuldade de investimento ou de financiamentos por parte de alguns granjeiros (SEAGRI, 2010). 


\section{OBJETIVOS}

\subsection{Objetivo geral}

Analisar o impacto socioeconômico das políticas sanitárias avícolas para a atividade de produção de ovos em atendimento às legislações para o registro de estabelecimentos avícolas comerciais, sobre os estabelecimentos avícolas de postura localizados na regional agropecuária de Limeira, Estado de São Paulo.

\subsection{Objetivos específicos}

a) Analisar o perfil socioeconômico dos estabelecimentos avícolas e dos produtores de ovos localizados na regional agropecuária de Limeira, Estado de São Paulo;

b) Estimar o custo de produção de ovos e das medidas de biosseguridade preconizadas pelas Instruções Normativas n56/2007, n59/2009, n`36/2012 e n¹0/2013, nos estabelecimentos avícolas comerciais de postura e, analisar seu impacto. 


\section{REVISÃO DE LITERATURA}

\subsection{Avicultura no Brasil}

A galinha foi um dos primeiros animais domésticos que chegou ao Brasil, junto com Pedro Álvares Cabral, conforme descrito na carta do escrivão Pero Vaz de Caminha, enviada ao governo português na ocasião do descobrimento. No Brasil, ao longo da história, praticava-se a avicultura tradicional e familiar, também conhecida como produção de frango "caipira", produzida para o próprio consumo (PASIAN; GAMEIRO, 2007).

Conforme Hellmeister Filho (2003), no período entre 1900 e 1930, a avicultura passou por um período chamado "colonial", no qual as aves eram criadas totalmente soltas e sem nenhum critério específico de produção. Durante os anos de 1930 a 1940, foi a vez do período denominado "romântico", em que os criadores valorizavam características relacionadas à beleza da ave, como a variação das cores das penas, tamanho da ave, forma das cristas e barbelas.

Entre os anos de 1940 a 1960, em plena época de escassez de alimentos provocada pela Segunda Guerra Mundial ocorreu o período das "aptidões mistas", onde as aves para a produção de carne e ovos passaram a ser criadas no sistema de parques com acesso livre a áreas de pasto e também dentro de galpões. Já nos anos de 1960 a 1970, começou a se moldar o que seriam os princípios da criação industrial, tão amplamente utilizada atualmente. Naquela época se começou a "especialização de raças" e as aves passaram a ser criadas dentro de galpões, surgindo então o confinamento. Daí para frente cada vez mais foi intensificando esse sistema de criação (HELLMEISTER FILHO, 2003).

Entre 1970 e 1975, deu-se origem ao período "super industrial", onde as linhagens comerciais, no sistema confinado, passaram a dominar o mercado com excelentes resultados de produção. No período entre 1975 a 1988, surgiu o período de "exportação" em que o frango inteiro foi o principal produto e, a partir de 1988 , com as mudanças das exigências no mercado consumidor nacional e internacional, deu-se início ao período de "processamento", onde os mais variados tipos de 
produtos produzidos a partir da carne do frango e de ovos tomaram conta do mercado (HELLMEISTER FILHO, 2003).

O surgimento, de fato, da indústria avícola no Brasil ocorreu, portanto, na década de 1970. A redução da produção extensiva de gado retroalimentava o aumento do cultivo de grãos, pois a transição para um modo intensivo de criação exigia cada vez mais a utilização de rações animais. O aumento da produtividade dos grãos e a incorporação de novas áreas para o seu cultivo não apenas reduziu a produção extensiva de bovinos como, também levou à agregação de valor com a transformação desses cereais em proteína animal (GIROTTO; MIELE, 2005).

A indústria avícola brasileira está fortemente instalada no Estado de São Paulo e na Região Sul do País. Isso se deve fundamentalmente à expansão da cultura de soja e milho nessas regiões, dado que o milho e o farelo de soja correspondem a cerca de $80 \%$ dos insumos da avicultura (RIZZI, 1999).

Segundo dados da Coordenadoria de Defesa Agropecuária (CDA), publicados no "Plano Estadual de Contingência para Influenza Aviária e Doença de Newcastle", São Paulo (2010a), a avicultura paulista era a terceira maior produtora de frangos de corte do País, com uma população de 135,8 milhões de aves no setor. O Estado era o primeiro em produção de ovos para consumo, com mais de 36,1 milhões de aves e o primeiro em produção de material genético (bisavozeiros, avozeiros, matrizeiros e incubatórios). A estrutiocultura e outras espécies de aves como codornas, marrecos, patos, galinhas de angola e perus, somavam mais de 3,47 milhões de cabeças. A soma da capacidade de alojamento de todos os estabelecimentos avícolas no Estado de São Paulo era de 181,3 milhões de aves (SÃO PAULO, 2010a).

No que se refere à produção de ovos de galinhas, segundo dados da Organização da Nações Unidas para Agricultura e Alimentação (FAO, 2012), o Brasil é o sétimo maior produtor mundial. O País produziu, em 2011, 31,5 bilhões de ovos, o que correspondeu a $3,1 \%$ da produção mundial. O consumo de ovos por pessoa por ano no País chegou a 162,5 unidades em 2011, contra 148,8 em 2010. Segundo dados da UBABEF (2013), o consumo em 2012 foi de 161,53 unidades por pessoa. A cadeia produtiva de ovos no Brasil se caracteriza pela produção para consumo in natura e industrializado.

Segundo Paraguassu (2013), a produção mundial de ovos triplicou nos últimos 40 anos passando de 20 milhões de toneladas em 1970 para 
aproximadamente 60 milhões em 2010. Sendo que neste mesmo período os países desenvolvidos mantiveram praticamente estáveis sua produção que, em 1970 estava em torno de 15 milhões de toneladas e, em 2010 aproximadamente 19 milhões de toneladas, representando um crescimento de $30 \%$. A China representou grande parte deste crescimento. Em 1970 a China produzia apenas 1,5 milhões de toneladas de ovos e hoje, representa aproximadamente $37 \%$ da produção mundial, 23,6 milhões de toneladas. Ainda de acordo com Paraguassu (2013), a FAO estima que a produção mundial de ovos, será de 90 milhões de toneladas até 2030.

Segundo dados do Instituto Brasileiro de Geografia e Estatística - IBGE (2012), em 2011 a região Sudeste possuía aproximadamente $46 \%$ do plantel nacional, seguida pela região Sul (26\%), Nordeste e Centro-Oeste (13\%) e Norte (2\%). O Estado de São Paulo era o maior produtor, com mais de 36 milhões de aves alojadas no Estado. O segundo e terceiro lugares pertenciam aos Estados de Minas Gerais e Paraná, com aproximadamente 13,5 milhões de aves cada. Com o quarto plantel aparecia o Rio Grande do Sul, com 10 milhões de aves, seguido de Santa Catarina com 7 milhões de aves e Pernambuco, com 5 milhões de poedeiras alojadas em 2011(IBGE, 2012). De acordo com dados da UBABEF (2013), em 2012, o Estado de São Paulo continua sendo o maior produtor de ovos (36,59\%), seguido dos Estados de Minas Gerais (11,73\%), Espírito Santo (7,69\%), Paraná (7,14\%), Mato Grosso (6,10\%), Pernambuco (5,92\%) e Rio Grande do Sul (5,29\%).

De acordo com Auler et al. (2009), até o ano de 2003 as poedeiras no Brasil atingiriam o número de 79 milhões de aves, a produção de ovos alcançaria 62,8 milhões de caixas de 30 dúzias, totalizando uma oferta 22,6 bilhões de unidades. Segundo dados do IBGE (2012), em 2011, as poedeiras no Brasil atingiram um número de 120 milhões de aves e a produção de ovos totalizou uma oferta de 30,8 bilhões de unidades. Já em 2012, segundo dados do IBGE (2013), o numero de poedeiras atingiu 126 milhões de aves, com uma oferta de 32,3 bilhões de unidades.

De acordo com dados da UBABEF (2013), em 2012, 99\% da produção de ovos foi destinada ao mercado interno e $1 \%$ foi exportada, tendo como principais destinos África e Oriente Médio. O Estado de Minas Gerais é o líder, representando $55,52 \%$ das exportações de ovos, seguido pelos Estados do Rio Grande do Sul $(39,26 \%)$, Mato Grosso do Sul $(3,13 \%)$, São Paulo (1,85\%), Rondônia $(0,12 \%)$ e Paraná $(0,03 \%)$. 
De acordo com Kakimoto et al. (2013), a avicultura de postura se desenvolveu no Estado de São Paulo exportando ovos para todo o Brasil, tanto paras regiões de fronteiras agrícolas como para grandes centros consumidores desde a década de 60 . A tecnologia desenvolvida na produção de ovos e a gestão da produção foram decisivas para tornar São Paulo o maior produtor de ovos. A cadeia produtiva do ovo no Estado de São Paulo é competitiva pelo entendimento das análises dos direcionadores de gestão da produção e tecnologia que tem revelado a sua contribuição favorável.

Segundo Goldberg (1968), o sistema agroindustrial (SAG) é compreendido por uma cadeia de operações que envolvem os elos a montante e a jusante, desde a fabricação de insumos, a produção nas granjas, a transformação (industrialização), a distribuição e a comercialização, chegando ao consumidor final. O sistema agroindustrial dos ovos foi considerado por Mizumoto (2004) como sendo de baixo desempenho no mercado nacional e internacional.

No Brasil, segundo Mizumoto e Zylbersztajn (2008), o sistema agroindustrial de ovos movimenta $R \$ 1,1$ bilhão por ano, sendo $23 \%$ destinado a rações, $12 \%$ aos salários e $25 \%$ à distribuição dos ovos. Estes autores também caracterizaram os pontos fracos deste sistema como: a relação informal entre os produtores e compradores, a sua lenta modernização, o seu baixo crescimento, o reduzido nível de investimento em pesquisas e a falta do conhecimento das propriedades nutricionais do ovo pelos consumidores.

De acordo Paraguassu (2013), em todo o mundo, a produção de ovos ainda é considerada uma indústria de baixa concentração, exceto em alguns poucos países como os EUA e Mexico. Dentre os 12 maiores produtores independentes de ovos no mundo, 7 estão nos EUA, 3 no México, 1 na Ucrânia e 1 no Brasil, sendo que todos estes tem maior parte de sua produção destinadas a ovos brancos.

De acordo com Sobrinho e Fonseca (2007), o ovo já foi considerado um dos melhores alimentos para o homem e apesar de ser "bom, barato e saudável", ainda não conseguiu seu lugar no mercado de consumo. Pelo menos no Brasil, o ovo foi submetido a uma propaganda negativa nas décadas de 80 e 90, fazendo com que a população resistisse em conhecê-lo e consumi-lo. Para Neto et al. (2013a), também se faz necessário quebrar esses velhos paradigmas, tal como o ovo representar um vilão à saúde, devido ao colesterol. Isto só será possível se houver informação ao 
consumidor, investimentos em marketing e, principalmente, união dos produtores e do governo para colocar em prática tais ações.

Ainda de acordo com Neto et al. (2013a), a maior valorização dos aspectos nutritivos e funcionais do ovo pelos consumidores depende da qualidade que estes são oferecidos ao mercado, sendo aspecto de influência na aceitação, nos hábitos e decisões do consumidor final. $O$ mesmo autor acredita que futuramente 0 consumidor terá sua preferência não vinculada apenas ao preço, mas também à qualidade. Além do aspecto econômico, há crescente preocupação da sociedade relativa ao meio ambiente e ao bem-estar das aves, surgindo um desafio para avicultura de postura.

Para Lana (2000), existem dois tipos de ovos comestíveis produzidos e comercializados no mercado. Os ovos de casca branca e os de coloração marrom, também chamados de "vermelhos". A cor dos ovos depende da linhagem das aves. As poedeiras de origem da raça Leghorn Branca dão origem aos ovos com casca branca, já as aves de origem das raças Rhodes Island Red, New Hampshire e Leghorn Vermelha, originam ovos de casca vermelha. Segundo Mizumoto (2004), a produção de ovos brancos predomina sobre a produção de ovos vermelhos. O Sul do País concentra a maior produção de ovos vermelhos, mantida pela herança cultural. Nas outras regiões predominam os ovos brancos, acompanhados de uma produção de ovos vermelhos, proporcionalmente menor.

A produção é feita predominantemente no sistema de criação em gaiolas, com granjas de cria e recria separadas das granjas de produção. $O$ regime de criação intensivo, onde os animais ficam totalmente confinados, é o mais empregado, pelo fato do aumento da produção e eficiência da atividade. Essa eficiência é consequência do trabalho de melhoramento genético das aves, da coleta de dados, da mensuração de variáveis como o peso corporal, do consumo de alimento, da conversão alimentar, da mortalidade reduzida, do rendimento de carcaça, além do uso de novas tecnologias em instalação, manejo, nutrição, bem estar e higiene (BOARETTO, 2009).

Segundo Van Horne e Acterbosch (2008), quanto às instalações, atualmente no Brasil predomina o uso de gaiolas convencionais, com espaço de 300 a $400 \mathrm{~cm}^{2}$ por ave, possuindo um dos menores custos de produção do mundo, devido aos reduzidos gastos com alimentação e mão de obra, além da falta de legislação que regulamente a criação de poedeiras. Porém, para os mesmos autores, se o Brasil 
quiser exportar ovo, mesmo que em pó, para países da Comunidade Europeia, terá que substituir as gaiolas convencionais por gaiolas enriquecidas (ou mobiliadas com ninho, poleiro e banho de areia/cama), com pelo menos $750 \mathrm{~cm}^{2}$ por ave, ou por sistemas alternativos, com até $1.100 \mathrm{~cm}^{2}$ por ave.

De acordo com Alves et al. (2007), o sistema de criação em gaiolas tornouse uma das maiores polêmicas acerca do bem-estar animal. $O$ reduzido espaço oferecido e a ausência de caracteres de enriquecimento ambiental impossibilitam ou limitam o repertório de atividades consideradas importantes para o animal. A União Europeia (1999) baniu o uso de gaiolas para poedeiras a partir do ano de 2012, através da Diretiva № 74 de 1999, o que pode implicar no aumento do custo de produção.

Segundo Gavinelli (2013), diretor da Unidade de Bem-Estar Animal do Diretório Geral da Comissão Europeia para a saúde e proteção do consumidor DGSanco, com relação ao bem-estar das galinhas poedeiras preconizadas pela Directiva $n^{\circ} 74$, a Comissão Europeia agiu rapidamente para garantir que vários Estados-Membros conseguissem atender aos requisitos o mais rapidamente possível. A transparência na cadeia do mercado por meio de um rótulo específico nos ovos, o conhecimento de vários cidadãos sobre a questão e o suporte dos varejistas fizeram com que se solucionasse rapidamente a difícil situação de $1^{\circ}$ de janeiro de 2012, data em que a diretiva entrou em vigor, quando cerca de $30 \%$ das poedeiras da UE não eram mantidas em gaiolas melhoradas e adequadas.

No entanto, ainda segundo Gavinelli (2013), em junho de 2013, estimou-se que apenas $4 \%$ da população total de poedeiras da União Europeia ainda eram mantidas nos antigos sistemas de gaiolas e que os produtores encontraram dificuldades em virtude da situação econômica da Europa, no entanto relata que a situação continua melhorando com a eliminação gradual e completa dos antigos sistemas.

Segundo Hester (2005), o fato dos animais serem alojados em gaiolas e de, geralmente, não haver mistura de animais de diferentes idades em um mesmo galpão, há menor índice de mortalidade e enfermidades nos plantéis de criação avícola, além dos cuidados de vacinação e higiene, que neste sistema é maior. Há controvérsias quanto à melhor instalação a ser utilizada para poedeiras, pois as gaiolas tradicionais possuem alguns benefícios, tais como melhor controle de 
enfermidades, menor produção de amônia e vantagens econômicas, quando comparadas ao sistema alternativo de criação.

De acordo com Fassarela e Covre (2010), o processo de produção inicia-se com a compra de pintainhas com um dia de vida para a cria e recria que, por sua vez, constitui no desenvolvimento da pintainha em franga. Esta etapa dura em média 18 semanas e, após esse período as frangas são transferidas para o galpão de produção. A produção consiste em dois ciclos: o primeiro ciclo dura 80 semanas, período em que a produtividade das aves atinge o ponto máximo e declina. Nesta fase, o produtor pode descartar as galinhas ou entrar no segundo ciclo de produção procedendo a muda forçada, que é um processo que dura aproximadamente 28 dias, nos quais as aves, durante 10 a 12 dias não recebem alimento e durante um dia também não recebem água.

Ainda de acordo com Fasarela e Covre (2010), durante o período de muda forçada as aves mudam todas as penas e diminuem o peso, tendo como objetivo a renovação do aparelho reprodutor, iniciando um novo ciclo produtivo por mais 36 semanas. Posteriormente ao segundo ciclo, as aves são descartadas e o galpão de produção recebe um novo plantel. Ainda de acordo com os mesmo autores, esta decisão é tomada baseada no preço do ovo. Se o preço do ovo estiver alto, o segundo ciclo de produção é efetuado, caso contrário as aves são descartadas.

Quanto ao estresse sofrido pelas aves durante o período da muda forçada, Laganá et al. (2013), concluiu que o mesmo pode ser amenizado através da oferta de $15 \%$ de ração diariamente sem prejuízos para o processo de muda e que a oferta de calcário durante o processo não afeta a qualidade de ovos e desempenho das aves durante a muda.

Ainda de acordo com Fassarela e Covre (2010), as disparidades entre os avicultores no processo de produção são relativas, basicamente, à mecanização da produção. Os pequenos avicultores produzem em galpões rudimentares, com colheita dos ovos e distribuição da ração, feitos manualmente. Em contrapartida, os grandes produtores possuem plantéis automáticos, com classificadoras elétricas, que, por sensor, classificam e embalam os ovos diminuindo o desperdício e consequentemente os custos.

O processamento dos ovos é uma etapa na qual os ovos são limpos, classificados e embalados. As instalações e equipamentos devem seguir as normas impostas pelo Regulamento de Inspeção Industrial e Sanitária de Produtos de 
Origem Animal - RIISPOA, no qual os estabelecimentos são classificados como entrepostos de ovos, que são os locais destinados ao recebimento, classificação, acondicionamento, identificação e distribuição dos ovos; e fábrica de conserva de ovos, estabelecimento destinado ao recebimento e à industrialização de ovos. (BRASIL, 1952).

Os atacadistas e varejistas são os principais agentes na distribuição de ovos. O trabalho do atacadista consiste no suprimento de canais menores, mediante repasse da mercadoria. O varejista compra a mercadoria diretamente do entreposto, ou do atacadista, e seu trabalho é disponibilizar o produto para o consumidor final (MIZUMOTO, 2004). Para Martins (1996), os atacadistas desempenham um papel que não se restringe apenas à distribuição de ovos. Os varejistas têm preferências por tipos de ovos que o produtor tem dificuldade em atender, pois a distribuição de tipos de ovos está diretamente relacionada com a distribuição de idade dos lotes e alguns aspectos de manejo. Dessa forma, os atacadistas garantem espaço de intermediação, além de promover a substituição de mercadoria com ovos quebrados ou trincados, reposição de mercadoria nas gôndolas e manutenção de um estoque de equilíbrio.

De acordo com Mizumoto e Zylbersztajn (2008), os contratos de fornecimento são utilizados por grandes redes de supermercados. Na maioria dos casos, preços e quantidades não são determinados pela via contratual. A figura do contrato existe, em um extremo, para efeitos cadastrais e, em outro, para exigir exclusividade de fornecimento. Existem divergências entre os entrepostos de ovos na questão do fornecimento para grandes redes de supermercados. Os entrepostos que firmam contratos com supermercados procuram segurança nas vendas, atrelada à reputação do cliente, enquanto outros recusam 0 fornecimento pela obrigatoriedade de prazo, descontos e bonificações (MIZUMOTO; ZYLBERSZTAJN, 2008).

Segundo Donato et al. (2009), grande parte da produção é comercializada no mercado interno, tendo o setor se adequado nos últimos anos para tentar incrementar as exportações. Entretanto, para atender as exigências do consumidor nacional e do mercado internacional existe a necessidade da contínua implementação de programas que garantam elevado padrão de qualidade dos ovos de mesa e dos produtos à base de ovo. No sentido de conduzir a fase atual para uma situação mais segura e competitiva surge a necessidade de instruir produtores 
rurais para uma mudança de hábito, costume e atitude no trato dos animais e dos produtos alimentícios. Ainda de acordo com o mesmo autor e colaboradores, a aplicação de boas práticas de produção e, em especial, as que visam à preservação do meio ambiente, bem como o bem estar animal e dos trabalhadores, devem ser consideradas para o progresso da atividade avícola e para a inserção definitiva do setor no mercado mundial.

De acordo com Kakimoto et al. (2013), apesar dos pontos favoráveis tanto para gestão da firma como tecnologia, a produção de ovos do estado de São Paulo torna difícil o seu aumento devido a grande quantidade de estruturas e maquinários depreciados e que necessitam de reposição. Os mesmos autores, analisando os direcionadores pelo grau de decisão, individual ou coletivo, concluíram que os direcionadores dependentes de grau de decisão individual como a gestão da firma e tecnologia obtiveram melhores pontuações, favorável para a competitividade, contribuindo positivamente para a cadeia de produção de ovos. Ainda de acordo com Kakimoto et al. (2013), a cadeia produtiva do ovo no Estado de São Paulo poderia ser dinamizada através do aumento do mercado consumidor, estimulando 0 consumo per capita, ou mesmo com o aumento das exportações, bem como com a elaboração de programas de financiamento junto ao governo para renovação das instalações avícolas.

\subsection{Sanidade avícola}

\subsubsection{Biosseguridade na avicultura}

Segundo Mazzuco et al. (2006), a confiança do consumidor e a competitividade da cadeia são conquistadas quando há garantia da qualidade do alimento. Essa qualidade é obtida quando são aplicados procedimentos padronizados que podem ser adotados nos diferentes sistemas de produção, como as Boas Práticas de Produção (BPP), que englobam programas como o de Análise de Perigos e Pontos Críticos de Controle (APCC), Programa de Alimentos Seguros (PAS) e Procedimento Padrão de Higiene Operacional (PPHO). Ainda de acordo com Mazzuco et al. (2006), o Ministério da Agricultura Pecuária e Abastecimento - 
MAPA, estabelece a utilização de tais programas por agregarem medidas de monitoramento e controle na forma de registros ou certificações, que satisfazem exigências sanitárias, de boas práticas de manejo, produção ou fabricação e de segurança alimentar em todos os estágios de produção.

De acordo com Buim et al. (2013), a prevenção e o controle de patógenos são desafios constantes no setor avícola. $O$ ambiente avícola pode ser uma fonte potencial de infecções e, a gravidade e ocorrência de enfermidades estão diretamente relacionadas ao nível de contaminação do ambiente. A introdução de agentes de enfermidades nos sistemas de criações pode ocorrer por trânsito de passageiros, importação de animais e material genético, produtos biológicos, lixo de bordo de aviões e navios, correspondência postal, além da transmissão por aves migratórias. Assim, todos os países em risco de terem animais acometidos devem implementar sistemas de monitoramento eficientes. Ao se comprovar o aparecimento de um foco, este deve ser rapidamente contido, impedindo que esse se espalhe para regiões vizinhas (BRASIL, 2006a).

Segundo Sesti (2001), a única maneira de se manter sistemas de produção e seus respectivos rebanhos comerciais livres ou controlados, no que diz respeito à presença de agentes de enfermidades de impacto econômico na produtividade e/ou perigosos para a saúde pública, seria por meio da utilização de um efetivo programa de biosseguridade. Este deve contemplar os aspectos gerais da Medicina Veterinária Preventiva, bem com conter aspectos exclusivos direcionados à cada sistema de produção em particular. A saúde animal sempre foi uma das principais, senão a principal barreira não tarifária para embargo de exportações brasileiras ao resto do mundo. Assim, biosseguridade é o quesito básico para a qualidade dos produtos, tanto para o cada vez mais exigente consumidor interno, quanto para 0 mercado externo.

De acordo com Sesti (2005), biosseguridade é uma palavra relativamente nova no vocabulário. Em seu sentido geral ela significa o estabelecimento de um nível de segurança de seres vivos por intermédio da diminuição do risco de ocorrência de enfermidades agudas e/ou crônicas em uma determinada população. Este conceito geral é aplicável às populações de qualquer espécie animal. É ainda, um conceito técnico ou uma filosofia técnica aplicada à saúde de seres vivos animais, e no presente caso, a plantéis da moderna avicultura industrial. 
Ainda conforme mencionado por Sesti (2005), a implantação de bons programas de biosseguridade inicia-se na elaboração de ações de controle a serem estabelecidas e seguidas nas normas específicas, as quais findam na sua aplicação prática no campo e nas atividades diárias. Antes da elaboração e da implantação de qualquer programa de biosseguridade, é necessário que seja realizada uma análise e definição dos riscos e desafios aos quais os sistemas de produção estão sujeitos. Médicos Veterinários responsáveis pela biosseguridade de um sistema de produção de aves enfrentam um significativo desafio ao irem ao encontro das demandas competitivas do mercado, as quais devem ser respondidas com mudanças estratégicas e operacionais no que se refere à biosseguridade do sistema de produção.

Em 2004, a Organização Mundial de Saúde Animal (OIE) introduziu o conceito de "divisão em setores" no capítulo "Zonagem e Regionalização", do seu Código Sanitário dos Animais Terrestres, no qual descreve os conceitos de divisão em zonas e em setores como: "procedimentos aplicados por um país nos termos do presente capítulo com vista a definir no seu território subpopulações de status sanitário diferente para efeitos de controle de doenças e/ou de comércio internacional". Um setor de criação pode ser constituído por diversos estabelecimentos e pode ser aprovado para enfermidades animais definidas, com base em um plano de biosseguridade pormenorizado e documentado redigido e executado para as enfermidades em causa (OIE, 2004).

O Brasil, por meio do MAPA, encaminhou em 2011 um projeto de compartimentação da avicultura industrial para a prevenção de Influenza Aviária e Newcastle à Organização Mundial de Saúde Animal (OIE). O conceito de "compartimentação" elimina a questão geográfica. Com isso, mesmo no caso de surtos de determinadas doenças em um Estado ou região, a empresa compartimentada pode continuar a exportar. O contrário também é verdadeiro. Se houver algum problema em uma determinada instalação, apenas a empresa é interditada e não toda uma região ou Estado.

De acordo com a revista Avicultura Industrial (2011), o projeto, resultado de quatro anos de estudos e pesquisas, consistiu de uma parceria entre o MAPA, os Órgãos de Defesa Agropecuária Estaduais, a União Brasileira de Avicultura e Associação dos Exportadores de Frango (UBABEF), principal entidade do setor avícola, e a iniciativa privada. Com este projeto, o setor avícola nacional deverá se 
tornar mais efetivo na detecção e combate a eventuais problemas sanitários e, em caso de surtos dessas doenças, as propriedades que estiverem seguindo as medidas de controle e biosseguridade serão consideradas livres para produzir e comercializar seus produtos. Ainda de acordo com a revista, o MAPA irá auditar, fiscalizar e certificar os estabelecimentos após a adoção das medidas preventivas. $O$ reconhecimento será feito em toda a cadeia produtiva, ou seja, desde a granja de reprodução, incubatórios, granjas de corte e de postura, abatedouros, fábricas de ração e de materiais para cama de aviários. A medida pretende favorecer a manutenção dos mercados compradores em casos de surtos de enfermidades.

No entanto, para o êxito de um programa de biosseguridade na prevenção e controle das doenças aviárias nas granjas, é necessária uma ação de educação continuada, envolvendo a participação de todas as pessoas que atuam na produção (SESTI, 2005).

\subsubsection{Principais enfermidades sob vigilância na avicultura}

A Organização Mundial de Saúde Animal (OIE) listou 115 enfermidades de notificação obrigatória, sendo que 12 delas são de aves, destacando-se a Influenza Aviária, de alta virulência, a Doença de Newcastle, as Micoplasmoses, as Salmoneloses e a Laringotraqueíte Infecciosa. Outras doenças infecciosas de disseminação entre as aves e entre outras espécies como o homem, de importância para saúde animal e saúde pública, devem ser investigadas e controladas e/ou erradicadas pelo serviço veterinário oficial de defesa sanitária animal, dependendo da situação epidemiológica e do risco sanitário (BRASIL, 2002b). A lista de doenças passíveis da aplicação de medidas de defesa sanitária animal foi disponibilizada na Instrução Normativa $n^{\circ}$ 50, publicada pelo MAPA em 24 de setembro de 2013 (BRASIL, 2013c).

A Influenza Aviária (IA) e a Doença de Newcastle (DNC), portanto, fazem parte da lista das enfermidades infecciosas de declaração obrigatória à OIE, que reúne as doenças cujas consequências socioeconômicas podem ser graves e de grande importância no comércio internacional de aves e seus produtos, sendo seus focos de notificação compulsória. Os vírus da IA e da DNC são de grande 
importância econômica para avicultura industrial mundial e seu diagnóstico de rotina em laboratórios credenciados é preconizado pelas autoridades da Secretaria de Defesa Agropecuária do MAPA (BRASIL, 1994). Paulillo (1984) relatou que, assim como a IA, a DNC é considerada um dos problemas sanitários mais importantes do plantel avícola brasileiro, em virtude dos elevados prejuízos que pode ocasionar.

Segundo Bockma (1998), um surto da DNC em aves ornamentais, devido a uma estirpe velogênica viscerotrópica do vírus na Califórnia, Estados Unidos da América, em 1998, resultou na proibição das exportações de carne de frango para Rússia, Japão, Estônia, Marrocos, Nova Zelândia e Romênia. A barreira sanitária persistiu até a erradicação total da cepa patogênica, não havendo sua difusão para aves de exploração comercial. King (1999), relata que um surto da Doença de Newcastle em frangos de corte, em Nova Gales do Sul, Austrália, em abril de 1999, resultou em cancelamento das exportações de todos os produtos avícolas daquele País para a China.

De acordo com a publicação do "Plano de Contingência para Influenza Aviária e Doença de Newcastle", Versão 1.3 (BRASIL, 2009b), por razões não claras, um aumento na detecção de surtos de IA no mundo ocorreu no final dos anos 90 e início do século XXI. Focos de Influenza Aviária de alta patogenicidade foram registrados em diferentes países, com detecção do agente em espécies da avicultura industrial. Esses focos causaram morte ou sacrifício de milhões de aves e expressivas perdas para a atividade.

Em conexão com esses episódios, vários casos de infecção humana foram reportados e alguns com registro de mortes. Segundo a OIE, a influenza aviária de notificação obrigatória é uma infecção em aves comerciais causada por qualquer vírus da influenza do tipo A, pertencente ao subtipo $\mathrm{H} 5$ ou $\mathrm{H} 7$, ou ainda por qualquer vírus de influenza aviária que apresente índice de patogenicidade intravenosa (IPIV) superior a 1,2 ou que seja causador de mortalidade superior a $75 \%$ (BRASIL, 2009b).

Em 1996 e 1997 ocorreram dois focos na China, sendo que o foco de 1997, em Hong Kong, foi o primeiro a notificar acometimento e morte de humanos com o vírus de origem aviária. Esses focos foram satisfatoriamente contidos e não houve mais ocorrência da doença até 2003. Desde então, vários focos vêm sendo identificados, inicialmente no sul da Ásia, mas estes têm se alastrado, atingindo países da Europa em 2005 e África em 2006 (VALENTE et al., 2009). 
Nos surtos asiáticos de 2003 e 2004, os efeitos locais foram muito severos, causando consideráveis perdas de produção. As perdas diretas foram maiores no Vietnã, no qual 44 milhões de aves morreram ou foram sacrificadas, correspondendo a 17,5\% do plantel nacional; e na Tailândia, 29 milhões de aves, correspondendo a $14,5 \%$ do plantel. Estima-se que os custos com o surto no Vietnã superaram 1,8\% do PIB do País, com aproximadamente 450 milhões de dólares (MCLEOD et al., 2005).

Em junho de 2012, na região de Altos de Jalisco, localizada no centro-oeste do México, foram reportadas elevadas mortalidades em estabelecimentos avícolas de postura. A enfermidade foi diagnosticada primeiramente como Cólera Aviária, depois como Doença de Newcastle, mas trava-se de um caso severo de Influenza Aviária. A autoridade veterinária sanitária mexicana reportou a presença do vírus tipo $\mathrm{A} / \mathrm{H} 7 \mathrm{~N} 3$, de alta patogenicidade e exótico, à OIE em 21 de junho de 2013 (MÁRQUEZ, 2013).

Ainda segundo Márquez (2013), até o final de outubro de 2012, 22,3 milhões de aves morreram ou foram sacrificadas, a um custo de US $\$ 760$ milhões, 160 milhões aves foram vacinadas e mais de 7000 empregos foram perdidos. Em janeiro de 2013 foram reportados mais dois casos de Influenza Aviária de Alta Patogenicidade (HPAl) em granjas de postura não vacinadas do Estado de Aguascalientes, e algumas semanas depois começaram a surgir relatos de mortalidades nos plantéis de matrizes de corte no estado de Guanajuato, localizada a sudeste de Jalisco (MÁRQUEZ, 2013).

Ainda de acordo com Márquez (2013), em maio de 2013 foi relatada a presença do vírus da IA em estabelecimento de poedeiras em Palmar del Bravo, Estado de Puebla, segundo maior produtor de ovos do México e localizada a cerca de 45 km de Tehuacán, fronteira com a Guatemala, alertando a grande possibilidade de infecção do setor de avicultura daquele País nos meses seguintes.

Segundo Márquez (2013), um enorme esforço de vigilância epidemiológica ativa foi implementado no estado de Jalisco, nos seis estados vizinhos e no restante do país, todas as ações sanitárias, de biosseguridade, mobilização, desinfecção e contingenciais foram tomadas para evitar a contaminação do setor avícola da América Central. O autor ainda considera que outros países devem aprender com experiência mexicana e recomenda ações como Procedimento Padrão de Higiene Operacional, Boas Práticas de Produção e implementar um Programa de 
Biosseguridade para prevenir e evitar a presença de um foco de Influenza Aviária, entre outras enfermidades.

De acordo com Gallo (2013), o México e Estados Unidos são os dois países da América mais expostos a rotas migratórias de aves provenientes de Ásia e Leste Europeu, zonas que historicamente têm sido endêmicas a IA de alta patogenicidade e DNC, sobretudo em virtude de inúmeras pequenas criações independentes de aves e um amplo mercado de aves vivas. Existem pelo menos duas grandes rotas provenientes de Ásia que chegam a Estados Unidos e mais três rotas que coincidem com o México. O Brasil e a maior parte de América do Sul têm apenas uma rota que provém dos Estados Unidos e a maior parte pelo oceano, o que dificulta a persistência de aves infectadas a chegarem ao País.

Para Quevedo (2006), o Brasil está preparado para agir em uma situação de emergência como a que viveu a Europa e a Ásia, pois tem planos específicos de uma vigilância ativa e de prevenção, como monitoramento de aves domésticas e selvagens. O País tem um laboratório de referência nacional, o Laboratório Nacional Agropecuário (LANAGRO). Segundo Domingues (2008), o estudo da atividade viral para Doença de Newcastle e Influenza Aviária demonstrou ausência de vírus patogênico para DNC e de qualquer estirpe do vírus da IA em território nacional.

Com relação às demais enfermidades de notificação obrigatória, de acordo com Yoder (1991), a micoplasmose aviária, primeiramente descrita na Inglaterra sob a denominação de pneumoenterite enzoótica, é causada pelos micoplasmas, que são importantes patógenos aviários, responsáveis por doenças respiratórias e articulares, podendo acarretar grandes perdas econômicas na avicultura brasileira e mundial. A micoplasmose apresenta-se como um dos principais problemas sanitários na cadeia produtiva avícola. Segundo Kleven et al. (1991), o Mycoplasma synoviae foi primeiramente descrito por Olson, em 1954, como agente causador da sinovite infecciosa das galinhas e dos perus.

Mohammed et al. (1987) e Hoerr et al. (1994) relatam que a micoplasmose aviária tem distribuição universal e, dentre as 20 espécies isoladas de aves, Mycoplasma gallisepticum (MG), M. synoviae (MS), M. meleagridis (MM) e M. iowae (MI) são considerados os principais agentes patogênicos para galinhas e perus, acarretando perdas econômicas devido ao decréscimo na taxa de crescimento e no ganho de peso; perdas por condenações de carcaças, devido à doença respiratória 
crônica em frangos de corte; bem como redução na produção e eclodibilidade de ovos, além dos custos com profilaxia e uso de drogas terapêuticas.

Com relação às salmoneloses, segundo Revolledo e Ferreira (2009), compreendem inúmeros sorotipos dos quais a Salmonella typhimurium e a Salmonella enteritidis representam os maiores desafios na produção de carne de frango e ovos, por sua relação com a saúde pública e a importância para o comércio internacional. Ainda de acordo com os mesmos autores, a Salmonella gallinarum e a Salmonella pullorrum, específicamente aviárias, são de especial importância econômica, sobretudo na diferença entre os países desenvolvidos, onde praticamente estão erradicadas, e os países em desenvolvimento, nos quais, apesar de existirem programas de controle, muitas vezes não existem sistemas de fiscalização e de monitoramento oficiais nas integrações avícolas, havendo, assim, a ausência de um conhecimento real do que ocorre dentro das granjas.

Classificada como doença de notificação compulsória à OIE, a Laringotraqueíte Infecciosa Aviária (LTI), é uma enfermidade de importância econômica e sanitária nas criações aviárias. A LTI é uma doença respiratória aguda e altamente contagiosa que acomete $o$ trato superior das aves. Surtos das doenças foram descritos desde 1925 nos EUA, México, Inglaterra, Irlanda, Escócia, Austrália, Nova Zelândia e Coréia. As medidas de controle devem incluir diagnóstico rápido, estabelecimento de um programa vacinal e prevenção da disseminação do vírus (REVOLLEDO; FERREIRA, 2009).

Segundo Buchala (2008), na região de Bastos, Estado de São Paulo, área de maior concentração de granjas de aves de postura no Brasil, em meados de 2002 a avicultura enfrentou problema nas aves que apresentavam grave manifestação de comprometimento respiratório, redução da postura de ovos e aumento da taxa de mortalidade, que não correspondiam aos procedimentos convencionais de vacinação e de antibioticoterapia praticados e aos indicadores de produtividade e de saúde verificados até então. Ainda de acordo com Buchala (2008), a ocorrência de LTI foi oficialmente notificada ao MAPA em 27 de dezembro de 2002, quando já era elevada a prevalência desta síndrome no plantel e com os prejuízos já instalados. A Coordenadoria de Defesa Agropecuária do Estado de São Paulo (CDA) instituiu um programa de saúde animal para o controle da doença, com base no planejamento de fases que foram implantadas durante o seu desenvolvimento e amparadas por instrumentos legais especificamente elaborados para esta finalidade. 
Em 2010 foi notificada a ocorrência da LTI pelo responsável técnico de uma das granjas de postura comercial do Município Paulista de Guatapará. Confirmado o diagnóstico, foram estabelecidas as exigências a serem cumpridas pelos estabelecimentos avícolas, visando a biosseguridade do sistema de produção avícola para 23 estabelecimentos (SÃO PAULO, 2010c).

\subsubsection{Políticas sanitárias}

Com a missão institucional de fomentar a produção e o desenvolvimento do agronegócio, seja pela manutenção do consumo interno ou pela exportação, o Ministério da Agricultura Pecuária e Abastecimento (MAPA), órgão governamental máximo em questões agropecuárias, tem entre seus princípios a geração de emprego e renda, a segurança alimentar, a inclusão social e a redução das desigualdades sociais. Órgãos dos governos estaduais no agronegócio, as Secretarias de Agricultura, têm papel fundamental no fortalecimento no desenvolvimento agropecuário (CASTRO, 2010).

Considerando a importância da produção avícola brasileira no contexto nacional e internacional, a necessidade de normatização das ações de acompanhamento sanitário relacionadas ao setor avícola e a necessidade de estabelecimento de programas de cooperação entre as instituições públicas e privadas, o MAPA publicou a Portaria Ministerial no 193 de 19 de setembro de 1994, que consolidou e estruturou o Programa Nacional de Sanidade Avícola (PNSA) (BRASIL, 1994).

A estruturação do PNSA está pautada no processo de parceria entre os segmentos públicos, privados e instituições de pesquisa, constituindo-se em um fórum permanente de discussões, sem descaracterizar o papel institucional dos diversos setores participantes. Os atos legais vêm sendo atualizados gradativamente em função da complexidade do seguimento de produção avícola e de outras explorações comerciais de aves, da implementação de ações sanitárias específicas e dos avanços técnicos e científicos que são as bases de construção e desenvolvimento do PNSA (BRASIL, 2002a). 
Quanto à atuação, o PNSA está pautado na execução das atividades de vigilância epidemiológica e sanitária das principais enfermidades aviárias destacando-se as de notificação à $\mathrm{OIE}$, em todas as unidades da Federação. A profilaxia, o controle e a erradicação dessas enfermidades consistem na aplicação de medidas de defesa sanitária animal. As diretrizes legais possibilitaram aos Estados da União não apenas executar as ações de saúde avícola, como também norteou a elaboração de programas estaduais (BRASIL, 2002a).

O Programa Nacional de Sanidade Avícola de 1994 recomendou a criação do Comitê Nacional Consultivo do PNSA e a criação de comitês estaduais. No Estado de São Paulo em 1995 foi criado o COESA (Comitê Estadual de Sanidade Avícola do Estado de São Paulo), pela Portaria da Delegacia Federal de Agricultura de São Paulo (DFA/SP) de número 28 de 03 de Março de 1995, iniciando imediatamente seus primeiros passos, realizando palestras de divulgação de seus objetivos, conhecimentos de epidemiologia e profilaxia das doenças objeto do PNSA, com o delineamento do Programa Estadual de Sanidade Avícola (PESA) (SÃO PAULO, 2010a).

Braço dos governos estaduais no agronegócio, as Secretarias de Agricultura têm papel fundamental no fortalecimento agropecuário. Ações como assistência técnica, extensão rural, trabalhos em prol da sanidade, produção, segurança alimentar, abertura de crédito, geração de tecnologia e informação, entre outros, constituem o leque de atuação destes órgãos. Especialmente no que tange à sanidade, as Secretarias Estaduais, por meio de suas Defesas Agropecuárias, têm papel fundamental no controle do trânsito animal e no combate às enfermidades (CASTRO, 2010).

As execuções dos programas de defesa sanitária animal no Estado de São Paulo são de competência da Coordenadoria de Defesa Agropecuária (CDA), órgão da administração pública direta do Governo do Estado vinculado à Secretaria de Agricultura e Abastecimento (SAA). A CDA foi instituída pelo Decreto Estadual $n^{\circ}$ 43.424, de 1o de setembro de 1998, que alterou a subordinação e o nível do Departamento de Defesa Agropecuária da Coordenadoria de Assistência Técnica Integral (CATI) da SAA (SÃO PAULO, 1998a).

O Departamento de Defesa Agropecuária passou a subordinar-se diretamente ao Secretário de Agricultura e Abastecimento, ficando sua denominação e seu nível hierárquico alterados para Coordenadoria de Defesa Agropecuária 
(CDA), definida e organizada pelo Decreto Estadual no 43.512, de 2 de outubro de 1998. Em 24 de outubro de 2000, foi promulgada a Lei Estadual $n^{\circ} 10.670$ que dispõe sobre a adoção de medidas de defesa sanitária animal no âmbito do Estado, regulamentada pelo Decreto Estadual n 45.781 de 27 de abril de 2001 (SÃO PAULO, 1998b, 2000, 2001a).

A Coordenadoria de Defesa Agropecuária tem por finalidade preservar e assegurar a qualidade sanitária dos rebanhos e das culturas vegetais de interesse econômico; controlar e monitorar a qualidade e utilização dos insumos agropecuários; controlar e fiscalizar a produção tecnológica e a qualidade dos produtos e subprodutos de origem animal e vegetal; certificar o padrão de qualidade sanitária das espécies animais e vegetais, utilizadas nas cadeias produtivas; e, controlar e monitorar a preservação, o uso e a conservação do solo agrícola (SÃO PAULO, 1998b).

O Programa Estadual de Sanidade Avícola (PESA) foi definido pelo Decreto no 45.782 de 27 de abril de 2001, no qual compete ao Secretário de Agricultura e Abastecimento, mediante Resolução, estabelecer os projetos específicos de prevenção, combate, controle e de erradicação das doenças e pragas, abrangidas pelos programas definidos no decreto e as medidas específicas de fiscalização e de defesa sanitária pertinente, mediante proposta da Coordenadoria de Defesa Agropecuária (SÃO PAULO, 2001b).

O Programa Estadual de Sanidade Avícola de que trata o Decreto № 45.782, de 27 de abril de 2001, passou a ser executado, no âmbito do Estado de São Paulo, de acordo com o Projeto de Prevenção, controle e Erradicação de doenças das aves constantes do anexo I da Resolução SAA n 54 de 12 de dezembro de 2006 e da legislação federal vigente (SÃO PAULO, 2006).

As principais atividades do Programa de Sanidade Avícola no Estado de São Paulo compreendem: um sistema contínuo de cadastramento dos estabelecimentos avícolas; a prevenção da ocorrência da Influenza Aviária, considerada exótica no País; a manutenção da erradicação da Doença de Newcastle, reconhecida desde 2003, por meio da IN n ${ }^{\circ} 11$ de 01 de setembro de 2003, que declarou os plantéis avícolas industriais do Estado de São Paulo e dos Estados do Rio Grande do Sul, Santa Catarina, Paraná, Minas Gerais, Goiás, Mato Grosso do Sul, Mato Grosso e do Distrito Federal livres da doença de Newcastle (BRASIL, 2003a), sendo o último foco no Estado de São Paulo detectado em 1993; o monitoramento das aves de 
descarte; o monitoramento e certificação dos núcleos de reprodução como sendo livres/controlados para as micoplasmoses e salmoneloses aviárias; a manutenção da Laringotraqueíte Infecciosa Aviária controlada com vacinação na região do bolsão sanitário de Bastos e Guatapará; o controle do trânsito de aves e ovos férteis por meio da emissão de GTAs pelo serviço oficial e pelos médicos veterinários habilitados; a implantação dos corredores sanitários e das fiscalizações em barreiras fixas e volantes; o monitoramento de sítio de aves migratórias; o treinamento do GEASE (Grupo Especial de Atenção à Suspeita de Enfermidades Emergenciais); a aquisição de equipamentos para atendimento em emergência sanitária e ações em educação sanitária (SÃO PAULO, 2010a).

O controle de enfermidades transmissíveis nas produções animais tem se baseado em intervenções que procuram interromper um ou mais elos conhecidos da cadeia epidemiológica de transmissão dos agentes causadores de doenças no homem e nos animais. A interação com o meio ambiente é complexa, envolvendo fatores ainda desconhecidos em dado momento ou que podem variar na medida em que novos conhecimentos são aportados, sejam descobertas científicas, terapêuticas, fisiopatogênicas ou epidemiológicas, seja pela observação sistemática do comportamento das doenças, frente à utilização dos procedimentos de controle $\mathrm{e}$ prevenção estabelecidos. A prevenção da ocorrência de doenças exóticas para a avicultura nacional é realizada pelo acompanhamento da situação sanitária mundial (BRASIL, 2002a).

As medidas de prevenção, controle e erradicação de doenças exóticas ou emergenciais estão amparadas na legislação em vigor. O Regulamento do Serviço de Defesa Sanitária Animal, aprovado pelo Decreto ㄲo 24.548, de 3 de julho de 1934 e a Lei o 569 de 21 de dezembro de 1948, estabelecem as medidas a serem aplicadas. Entre outra, no caso da constatação da Influenza Aviária ou Doença de Newcastle em plantéis avícolas, é obrigatório, por interesse da defesa sanitária animal ou da saúde pública, o sacrifício de animais acometidos. Como a doença não foi diagnosticada no País é obrigatório o sacrifício dos animais possíveis veiculadores da doença, a fim de manter o plantel avícola nacional indene (BRASIL, 1934, 1948).

O Decreto o 5.741, de 30 de março de 2006, institui o Sistema Unificado de Atenção à Sanidade Agropecuária (SUASA). Em sua Seção I, do mesmo capítulo, que trata dos controles de crises, estabelece que "o SUASA disporá de Manual de 
Procedimentos de Gestão de Crises", neste caso o "Plano de contingência para Influenza Aviária e Doença de Newcastle". Estabelece também que para a implementação das orientações contidas no Plano de Contingência, as três instâncias do SUASA, Central, Intermediária e Local, elaborariam, de forma proativa, planos de contingência e de emergência que definam as medidas aplicáveis imediatamente, adequadas às suas condições específicas. $O$ regulamento do SUASA define também que as Instâncias Intermediárias (Órgãos Executores Estaduais) prestarão assistência mútua, mediante pedido ou por iniciativa própria, sempre que os resultados dos controles oficiais impliquem adoção de medidas emergenciais por mais de uma Instância Intermediária (BRASIL, 2006b).

Tendo em vista o risco que a ocorrência da Influenza Aviária, de alta patogenicidade e que a Doença de Newcastle constitui para a avicultura brasileira, e ainda, considerando a importância socioeconômica que a atividade representa para o País, o MAPA aprovou, por meio da Instrução Normativa no 17 de 07 de Abril de 2006, o "Plano Nacional de Prevenção da Influenza Aviária e de Controle e Prevenção da Doença de Newcastle" em todo o território nacional, tendo como referência as recomendações da OIE para fortalecer os serviços de defesa sanitária animal e aumentar a capacidade de prevenção, atuação e investigação, atualizando e harmonizando normas e procedimentos para a prevenção da Influenza Aviária e a prevenção e controle da Doença de Newcastle (BRASIL, 2006a).

Assim sendo, o MAPA expediu o oficio circular DSA n 7, de 24 de Janeiro de 2007 e a Instrução Normativa DAS-MAPA n 32, de 13 de Maio de 2002, que aprova as Normas Técnicas de Vigilância para Doença de Newcastle e Influenza Aviária, e de controle e erradicação para a Doença de Newcastle. Assim, os responsáveis técnicos de matrizes e de poedeiras comerciais, deverão comunicar o serviço oficial de defesa sanitária animal quando for realizado o descarte dessas aves para que seja realizada a referida vigilância (BRASIL, 2002b, 2007a).

O rápido conhecimento sobre o aparecimento de sinais clínicos sugestivos de Influenza Aviária ou Doença de Newcastle em qualquer estabelecimento avícola tem importância decisiva no processo eficiente de contenção do agente e erradicação da doença. Essa notificação, preferencialmente, deverá ser feita por meio de comunicação direta ao serviço oficial de defesa sanitária, realizada através de chamado originado do proprietário ou médico veterinário de aves com sintomatologia sugestiva, denúncia anônima ou ainda pelas próprias autoridades 
sanitárias locais que trabalham em abatedouros de aves, através da identificação de sinais ou lesões sugestivas, verificadas nas inspeções ante e post mortem. A comunicação de suspeita sempre poderá ser feita: à Unidade Veterinária Local (UVL), à Coordenadoria de Defesa Agropecuária (CDA), à Superintendência Federal de Agricultura, (SFA), ou ainda diretamente ao MAPA (SÃO PAULO, 2010a).

Para atender ao PNSA, os estabelecimentos avícolas de controles permanentes e eventuais deverão obter registro e habilitação junto à Delegacia Federal de Agricultura (DFA) da jurisdição em que se localiza, estar sob vigilância e controle do Serviço de Sanidade Animal da DFA ou da Secretaria Estadual de Agricultura do Estado, e ser assistido por responsável técnico, registrado junto à DFA do Estado em que se está localizado (BRASIL, 2001, 2003b).

Deste modo, a Resolução SAA $n^{\circ}$ 54, de 12 de dezembro de 2006, considera a Influenza Aviária doença de peculiar interesse do Estado, aprova o Projeto de Controle e Erradicação das Salmoneloses, das Micoplasmoses e da Doença de Newcastle e de Prevenção e Combate da Influenza Aviária e estabelece as exigências a serem cumpridas pelos estabelecimentos avícolas de controles permanentes e eventuais, visando a biosseguridade do sistema de produção avícola e outras providências correlatas (SÃO PAULO, 2006).

Para realizar o comércio interestadual e internacional, o estabelecimento avícola deverá estar certificado como livre de micoplasmose aviária (Mycoplasma gallisepticum, Mycoplasma synoviae e Mycoplasma melleagridis). Sendo assim o MAPA publicou a Instrução Normativa no 44, de 23 de agosto de 2001, que aprova as normas técnicas para o controle e a certificação de núcleos e estabelecimentos avícolas de reprodução para a micoplasmose. Essas normas definem as medidas de monitoramento da micoplasmose em estabelecimentos avícolas de controles permanentes e eventuais, que realizam o comércio ou a transferência nacional e internacional de seus produtos, destinados à reprodução e produção de aves e de ovos férteis, ficando os mesmos obrigados a realizarem o monitoramento de seus plantéis, obedecendo as diretrizes do PNSA. Os estabelecimentos importadores ou compradores de material genético de linhas puras, bisavós e avós deverão obter previamente a garantia ou a certificação da origem, como livre de micoplasmas, de que tratam estas normas (BRASIL, 2001).

Com relação às salmoneloses, para proceder ao comércio nacional e internacional e a transferência, no âmbito nacional, de seus produtos, o núcleo ou 
estabelecimento avícola deverá estar certificado como livre das quatro salmonelas nos estabelecimentos de linhas puras, bisavozeiros e avozeiros. Os núcleos de matrizes deverão ter a condição de livres para Salmonella gallinarum e Salmonella pullorum e livre e/ou controlado para Salmonella enteritidis e Salmonella typhimurium, conforme determina a Instrução Normativa ํo 78, publicada em 03 de novembro de 2003, que aprovou as normas técnicas para controle e certificação de núcleos e estabelecimentos avícolas de reprodução como livres de salmoneloses. Os estabelecimentos importadores ou compradores de material genético de linhas puras, bisavós e avós deverão obter previamente a garantia ou a certificação de origem de livres para as salmonelas constantes destas normas (BRASIL, 2003b).

Segundo Buchala (2008), com relação à ocorrência da Laringotraqueíte Infecciosa na região de Bastos, a Portaria CDA n² 2, de 10 de janeiro de 2003, proibiu o trânsito interestadual de aves de descarte da região e deu início à fase preparatória. A Resolução SAA n 27 , de 30 de setembro de 2003, caracterizou a fase de execução com a delimitação da área infectada, denominada "Bolsão" de Bastos. A Portaria CDA $n^{\circ} 4$, de 20 de janeiro de 2004, estabeleceu um programa compulsório de vacinação contra a LTI. A partir de junho de 2004, nenhum novo caso de LTI foi observado no "Bolsão". A Resolução SAA n 43, de 17 de novembro de 2005, declarou a LTI controlada com vacinação, dando início à fase de consolidação das medidas de profilaxia implantadas e medidas de biosseguridade implantadas pelos avicultores.

No município de Guatapará foram estabelecidas medidas de profilaxia inespecíficas e específicas para o controle da Laringotraqueíte Infecciosa das Aves (LTI). As medidas inespecíficas são procedimentos gerais de biosseguridade aplicadas em estabelecimento ou região de exploração avícola visando a prevenção e o controle de agentes causadores de doenças nas aves e as específicas são procedimentos aplicados nas aves com a finalidade de prevenir e controlar a ocorrência de uma determinada doença aviária, por exemplo, o uso de vacinas e a interdição do estabelecimento avícola para a movimentação de aves (SÃO PAULO, 2010c). 


\subsubsection{Registro de estabelecimentos avícolas comerciais}

De acordo com Nelson (2013), o principal impedimento ao aumento no comércio internacional é a incerteza a respeito das restrições de importação. Segundo Sobrinho e Fonseca (2007), com relação à demanda, os surtos de enfermidades em aves podem afetar a confiança do consumidor e mudar padrões de consumo. Pela ótica da oferta, causa redução de produção nos países afetados pelas medidas de controle adotadas e barreiras não tarifárias à exportação de produtos advindos do País, reduzindo a oferta mundial. Além disso, afeta a confiança do investidor, o que pode causar consequências de longo prazo. Segundo Belusso e Hespanhol (2010), as barreiras técnicas e sanitárias do comércio internacional pressionaram as autoridades e os órgãos de Defesa Agropecuária a tomar medidas a fim de fixar os procedimentos para o registro, fiscalização e controle de estabelecimentos avícolas comerciais e de reprodução.

Objetivando o atendimento ao Programa Nacional de Sanidade Avícola (PNSA) e, ainda, ao Plano Nacional de Prevenção da Influenza Aviária e de Controle e Prevenção da Doença de Newcastle, o MAPA publicou em 04 de dezembro de 2007, a Instrução Normativa (IN) № 56, que estabeleceu os "Procedimentos para Registro, Fiscalização e Controle de Estabelecimentos Avícolas de Reprodução e Comerciais", revogando a IN $n^{\circ} 4$, que havia aprovado as normas para registro e fiscalização dos estabelecimentos avícolas na data de 30 de dezembro de 1998 (BRASIL, 1998, 2007b).

A IN 56 introduziu alguns procedimentos inéditos na avicultura comercial brasileira, como: telar todo galpão com malha de até $2,0 \mathrm{~cm}$; isolamento das granjas através de cercas, de maneira que impeçam a passagem de animais e de pessoas; desinfecção de veículos; registro das atividades documentado e arquivado; boas práticas de produção, entre outros (BRASIL, 2007b).

No entanto, atendendo a uma solicitação do setor, o MAPA publicou a Instrução Normativa no 59, de 02 de dezembro de 2009. Ela não revoga a IN 56, mas altera, entre outros dispositivos, os padrões métricos e os prazos fixados pela IN 56. O adiamento implica, no entanto, na exigência de adoção de medidas em prol da biosseguridade e manejo previsto na própria normativa, que entrou em vigor em 06 de dezembro de 2012 (BRASIL, 2009c). 
Considerando a Resolução SAA n 54, de 12 de dezembro de 2006, cuja ementa contempla a Influenza Aviária, doença de peculiar interesse do Estado, e aprova o "Projeto de Controle e Erradicação das Salmoneloses, das Micoplasmoses e da Doença de Newcastle e de Prevenção e Combate da Influenza Aviária", que estabelece as exigências a serem cumpridas pelos estabelecimentos avícolas de controles permanente e eventual, visando a biosseguridade do sistema de produção avícola, a CDA publicou em 17 de março de 2010 a Portaria n 8, que dispõe sobre os procedimentos para registro e fiscalização de estabelecimentos avícolas comerciais localizados no Estado de São Paulo (SÃO PAULO, 2006, 2010b).

Nesse sentido, todos os estabelecimentos avícolas comerciais do Estado de São Paulo, deverão ser registrados na Coordenadoria de Defesa Agropecuária, em atendimento à IN 56, complementada pela IN 59. Nesse segmento estão incluídos os estabelecimentos de aves comerciais de corte (exploração de aves para produção de frangos e perus para abate), os estabelecimentos de postura comercial (exploração de aves para produção de ovos de galinha para consumo) e os estabelecimentos de criação de outras aves (exploração de aves de produção como codornas, patos, marrecos, aves ornamentais, passeriformes, aves exóticas ou não, exceto ratitas, avestruzes e emas, e seus incubatórios) (SÃO PAULO, 2010b).

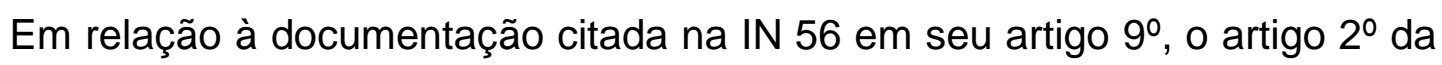
Portaria CDA no 8 estabelece que os documentos para registro do estabelecimento, devem ser entregues no Escritório de Defesa Agropecuária da circunscrição à qual pertence o estabelecimento avícola a ser registrado e que, conforme parágrafo único, após a análise documental, seja realizada visita de fiscalização para vistoria e, estando apto em receber o registro, será emitido o certificado de registro de estabelecimento avícola (SÃO PAULO, 2010a).

As adequações às normativas basicamente englobam itens de estrutura e procedimentos que visam aumentar o nível de isolamento dos plantéis para mantêlos com o melhor status sanitário possível. Através de programas de biosseguridade, objetiva-se reduzir os riscos de infecções em uma população de aves, aumentar o controle sanitário dos plantéis, minimizar a contaminação do ecossistema e resguardar a saúde do consumidor, através das boas práticas de produção. Com a regulamentação dessa atividade produtiva será possível intensificar as medidas para prevenção da entrada da influenza aviária no Brasil, assim como evitar outros possíveis problemas sanitários ao plantel avícola no País. O cumprimento dessa 
normativa é importante, pois trará mais segurança à cadeia produtiva e contribuirá para a melhoria contínua do setor (AVICULTURA INDUSTRIAL, 2012).

No entanto, mais uma vez por solicitação do setor, em 06 de dezembro de 2012 o MAPA publicou a Instrução Normativa $n^{\circ 36}$, alterando artigos e parágrafos da Instrução Normativa n ${ }^{\circ} 56$ de 04 de dezembro de 2007. Esta normativa excluiu da obrigatoriedade do registro os estabelecimentos avícolas que possuam até 1.000 (mil) aves e também exclui a obrigatoriedade da instalação de telas nos galpões de postura comercial do tipo californiano clássico ou modificado. Por serem considerados de maior suscetibilidade à introdução e disseminação de agentes patogênicos, esses estabelecimentos deverão adotar medidas adicionais, visando à mitigação do risco à introdução e disseminação de doenças (BRASIL, 2012).

Embora tenha sido excluída a obrigatoriedade do uso da tela nos galpões de postura comercial, Viana (2010), concluiu que a melhor eficiência técnica para biosseguridade das granjas avícolas foi da tela de alambrado na malha de $\leq 19,11$ $\mathrm{mm}$, pois as aves de vida livre não conseguiram passar através da malha nos ensaios. $\mathrm{O}$ autor considera ineficiente a tela à prova da entrada de pássaros de malha de $25,4 \mathrm{~mm}$, previsto na norma sanitária IN n59, e propõe-se o retorno da malha de até $20 \mathrm{~mm}$, como previsto na norma sanitária $\mathbb{I N} n^{\circ} 56$. Segundo Lourençoni et al. (2013), ao avaliar os dados zootécnicos analisados aliados às medições de temperatura concluíram que a presença de tela no galpão não altera a temperatura interna do galpão, o desempenho produtivo das poedeiras e a qualidade da casca do ovo.

Os estabelecimentos avícolas comerciais de maior suscetibilidade à introdução e disseminação de agentes patogênicos em seus plantéis serão submetidos a um programa de gestão de risco diferenciado, baseado em uma vigilância epidemiológica mais intensificada para as doenças de controle oficial do Programa Nacional de Sanidade Avícola (PNSA), com colheitas de amostras para a realização de testes laboratoriais. As medidas afetam principalmente os estabelecimentos avícolas comerciais não adequados aos procedimentos de registro (BRASIL, 2012).

Em 11 de abril de 2013 foi publicada a Instrução Normativa n 10, na qual foi definido o Programa de Gestão de Risco Diferenciado, baseado em colheitas de amostras para exames laboratoriais e adoção de vacinas, para os estabelecimentos avícolas considerados de maior susceptibilidade à introdução e disseminação de 
agentes patogênicos no plantel avícola nacional e para estabelecimentos avícolas que exerçam atividades que necessitam de maior rigor sanitário (BRASIL, 2013a).

A norma também define procedimentos de vigilância epidemiológica para controle dos sorotipos da bactéria salmonela (RURAL PECUÁRIA, 2013). De acordo com Neto et al. (2013b), o ovo muitas vezes é associado pelos consumidores à contaminação pela salmonela e, seu melhor conhecimento e controle podem resultar em ovos de melhor qualidade e uma alimentação mais segura, com benefícios para a população consumidora e, logicamente, para o setor avícola.

O sistema diferenciado inclui colheitas de amostras, regulares ou aleatórias, para a realização de testes laboratoriais para o diagnóstico de salmonelas. As colheitas devem ser feitas por médicos veterinários do serviço oficial ou que realizam o controle sanitário do estabelecimento avícola, sob fiscalização ou supervisão do serviço veterinário oficial. O material deve ser enviado para diagnóstico laboratorial a cada quatro meses. No caso de diagnósticos positivos para determinados sorotipos de Salmonella spp., o laboratório deverá encaminhar os resultados imediatamente ao serviço veterinário estadual e para a Superintendência Federal da Agricultura (SFA) do Estado onde se localiza o estabelecimento (BRASIL, 2013a).

\subsection{Perfil Socioeconômico na avicultura}

De acordo com Sluzz et al. (2006), o estudo do agronegócio é de vital importância para retratar as profundas transformações ocorridas na produção primária do País desde os anos 1990, período no qual o setor primário deixou de ser um mero provedor de alimentos in natura e consumidor dos próprios produtos, passando a ser uma atividade agropecuária que assume um status competitivo frente ao resto do mundo, que aos poucos vem se articulando de forma integrada aos setores industriais e de serviço. Segundo os mesmos autores, é reconhecida a importância do agronegócio para a geração de renda, emprego e divisas para o desenvolvimento do Brasil.

Desta forma, com relação à geração de renda, Rocha Jr. (2001) enfatiza que: "o êxodo rural é facilitado pelo fato do agricultor não conseguir manter uma renda mínima, o que impede o desenvolvimento sustentável da agricultura”. A 
diversificação do risco da cultura contribuiu para aumentar a renda do produtor. Para Franco (2000), embora o crescimento econômico seja necessário, não é suficiente para gerar o desenvolvimento. Não basta crescer economicamente, aumentando o Produto Interno Bruto (PIB) e a renda per capita da população, mas criar condições socioeconômicas melhores para a população como um todo.

De acordo com Sen (2000), é frequente observar que o crescimento econômico aumenta o número de ricos, mas, de pobres também, mantendo e até alargando as desigualdades, não produzindo desenvolvimento humano e social pretendido. Ainda de acordo com o mesmo autor, o desenvolvimento deve ser pensado além da acumulação de riqueza e aumento do PIB, e sim também estar relacionado com melhoria da vida e liberdade individual. O desenvolvimento ocorre quando há também a melhora do bem-estar do ser humano, conforme mencionado por Franco (1995): "uma comunidade se desenvolve quando torna dinâmicas suas potencialidades".

Sendo assim, o desenvolvimento socioeconômico de um País ou região está atrelado ao nível de investimentos existentes no País ou região. Investimentos estes não só atrelados ao crescimento econômico, mas também ao investimento em infraestrutura e formação social do cidadão. São assim considerados porque tanto o crescimento quanto o desenvolvimento econômico só ocorrem concomitante às inovações em tecnologia e conhecimento (CAIDEN; CARAVANTES, 1988). Para Rattner (1999), qualquer progresso na solução de problemas de desenvolvimento, locais ou globais, vai depender primariamente de ação coletiva, do envolvimento e da identificação e participação nos programas e projetos de pessoas suficientemente bem organizadas, educadas e motivadas.

De acordo com Rami (2013), os ovos de galinha têm representado um papel importante na alimentação humana desde o início da história. Segundo o mesmo autor, pode-se afirmar que os ovos são um dos poucos alimentos que são consumidos em todo o mundo, sendo a produção e a industrialização de ovos um importante segmento da indústria alimentícia. Segundo Sobrinho e Fonseca (2007), em virtude da produção de ovos ser uma atividade viável economicamente e factível tecnologicamente, essa é passível de realização em pequenas e médias propriedades rurais, tornando-se fundamental o desenvolvimento de estudos técnicos que abordem os aspectos tecnológicos, ambientais e econômicos da atividade. 
Segundo Pasian e Gameiro (2007), o sistema de criação convencional de galinhas poedeiras é atualmente o mais difundido, por apresentar altos índices de produção e custos relativamente baixos, pois, a adoção desse padrão tecnológico estava fortemente relacionada à conjuntura mundial no período pós-segunda guerra, onde a preocupação maior era produzir alimentos em grande escala para a população. Ainda de acordo com os mesmos autores, embora tais condições da criação industrial tenham proporcionado ganhos econômicos, também têm resultado em problemas quanto ao bem estar das aves, dada a utilização de certas práticas de criação e de manejo, e apesar da produção convencional ter muitos problemas relacionados ao bem estar, ela ainda é quem garante que a população de mais baixa renda tenha acesso a fontes de proteína animal, tendo uma grande importância social.

No entanto, para Martins (2000), o elo constituído pelos criadores é o mais frágil da cadeia produtiva, o que fica demonstrado pela sua perda de participação no preço de varejo. O maior problema que os criadores vêm encontrando é a baixa rentabilidade, causada por margens de lucro estreitas e mesmo negativas em certos períodos. Os aumentos de produtividade das poedeiras, que vêm sendo conseguidos pelo aperfeiçoamento das linhagens, das técnicas de arraçoamento e de manejo utilizadas, não têm resultado em melhoria na rentabilidade do produtor, pois têm sido repassados ao consumidor, via redução dos preços finais, e apropriados pelos intermediários e varejistas que, ao contrário dos criadores, têm conseguido manter suas margens.

Assim, o poder de barganha dos produtores frente aos atacadistas é pequeno e suas estratégias devem centrar-se em minimizar esse problema, via criação e fortalecimento de associações ou cooperativas de produtores, que poderiam inclusive utilizar a industrialização do ovo como forma de enxugar do mercado os excessos temporários de oferta, tornando os preços de mercado do ovo in natura mais estáveis (MARTINS, 2000).

As ameaças e oportunidades enfrentadas na atualidade pelos produtores são as mesmas do final dos anos 90: a globalização, os avanços tecnológicos e a desregulamentação do mercado. Neste cenário, muito se espera do marketing como meio de oferecer respostas eficientes para esse conjunto de desafios, pois geralmente esse é visto como responsável por criar, promover e fornecer bens e 
serviços a clientes sejam eles indivíduos ou empresas (SOBRINHO; FONSECA, 2007).

Segundo Paraguassu (2013), a indústria de produção de ovos tem um claro e sólido potencial de crescimento por aumento significativo da demanda populacional e o aumento de consumo de ovos pode ser incrementado mesmo em países e regiões de alto consumo e, o Brasil tem grande potencial para se tornar um produtor ainda mais importante dentro deste novo cenário global. Ainda segundo Paraguassu (2013), o futuro da produção mundial está bastante indefinido no momento. Enquanto alguns países estão buscando alternativas de redução de custo, outros enfrentam sérios desafios em relação às mudanças impostas nos sistemas produtivos, como por exemplo, a proibição do uso de gaiolas para galinhas poedeiras em alguns países da Europa.

\subsection{Custos de produção na avicultura}

Segundo Callado (2005), no estudo de sistemas agroindustriais, a análise de custos apresenta suma importância quando se busca identificar as principais restrições a uma melhor organização dos setores produtivos, como o setor de produção de ovos. Assim, a inserção da análise de custos no contexto do agronegócio é imprescindível para a expansão da sua competitividade tanto no mercado interno como no externo. A aplicação de um sistema de custos simplificado para as empresas agroindustriais permitirá o acompanhamento dos valores e de todas as operações realizadas na propriedade, possibilitando a descoberta das causas para a obtenção de lucro ou prejuízo (CALLADO, 2005).

Segundo Lopes e Carvalho (2002), a análise econômica da atividade é relevante, pois por meio dela o produtor passa a conhecer com detalhes e a utilizar, de maneira racional e econômica, os fatores de produção (terra, trabalho e capital). Dessa forma, localizam-se os pontos de estrangulamento, para depois concentrarem-se esforços gerenciais e tecnológicos, para obter sucesso na sua atividade e atingir os seus objetivos de maximização de lucros ou minimização de custos. Desta forma, a apuração da renda dos empreendimentos agrícolas, comparados aos custos totais de produção, fornece subsídios para observar em que 
grau foram recuperados os custos por meio dos produtos obtidos na empresa, produtos esses comercializados, estocados e/ou consumidos (LAMPERT, 2003).

De acordo com Raineri (2012), o processo de modernização da agricultura, observado durante o século $X X$ no Brasil, trouxe consigo a ideia de eficiência produtiva, ou seja, necessidade de maximizar o uso dos fatores de produção, a fim de obter maiores níveis de produtividade e rentabilidade. Nesse sentido, a administração rural se tornou uma alternativa para se identificarem os principais gargalos dentro dos sistemas produtivos, levantando informações que possam gerar intervenções a fim de aumentar a sua eficiência.

Sendo assim, segundo Martin et al. (1994), a utilização de estimativas de custos de produção na administração de empresas agrícolas tem assumido importância crescente, quer na análise da eficiência da produção de determinada atividade, quer na análise de processos específicos de produção, os quais indicam o sucesso de determinada empresa no seu esforço de produzir. Ao mesmo tempo, à medida que a agropecuária vem se tornando cada vez mais competitiva, o custo de produção transforma-se em um importante instrumento do processo de decisão. Assim, de acordo com o mesmo autor, se por um lado, os custos de produção vêm aumentando a sua importância na administração rural, na determinação de eficiência na produção de atividades produtivas e no planejamento de empresas, por outro, as dificuldades de estimá-los só recentemente começaram a ser reduzidas, à medida que aumenta a adoção da informática na gestão das empresas agropecuárias.

De acordo com Freitas (2001), assim como todos os setores produtivos de uma economia de mercado, a avicultura também é fortemente influenciada pela sua estrutura de custos. Inicialmente, existem os custos fixos, distribuídos entre a construção e manutenção dos galpões e da aquisição de equipamentos necessários à produção. Porém, alguns grupos de custos variáveis são mais expressivos dentro da cadeia produtiva, representando as maiores parcelas do custo total. Entre os mais importantes estão a produção de rações, de pintos e, o setor de insumos veterinários é composto de empresas fornecedoras de vitaminas, medicamentos $\mathrm{e}$ vacinas, entre outros (FREITAS, 2001). A indústria de instalações e equipamentos de avicultura de postura oferece desde a implantação de um aviário até grandes complexos de produção (MIZUMOTO, 2004).

Segundo Sobrinho e Fonseca (2007), a estrutura de investimento está composta de gastos com equipamentos e materiais para o processo de produção e 
taxas de impostos para regularizar a atividade, bem como gastos com remuneração de funcionários para a comercialização de ovos. Ainda de acordo com os mesmos autores, é fundamental desenvolver esta investigação para buscar soluções que visem a resolver problemas que atingem a todo o agronegócio e que correspondem à sua competitividade, viabilizando, dessa forma a cooperação entre produtores e consumidores como meio de assegurar a oferta e a qualidade da matéria-prima utilizada, no entanto poucos trabalhos são encontrados sobre análises de custos e lucratividade da avicultura de postura com definições de índices econômicos que possam servir de referências para novos estudos.

$\mathrm{Na}$ avicultura de postura, a importação de material genético e a produção local de avós, matrizes e pintainhas, rações, vacinas e as máquinas e equipamentos utilizados no processo de produção são os principais insumos. A produção do ovo inicia-se com a importação de material genético (bisavós), e produção no Brasil das avós e matrizes, e por meio destas as pintainhas, que são comercializadas para as granjas formarem seu plantel de poedeiras (LAGATTA et al., 2013). Segundo Kakimoto e al. (2013), a estrutura de mercado, a coordenação e o ambiente institucional têm comportamento neutro. Quanto à formação de preços de pintainhas, as empresas vendedoras devem buscar entendimento entre si, melhorando o relacionamento com os clientes na busca de parcerias sólidas.

Segundo Fassarela e Covre (2010), a nutrição de aves de postura procura a produção máxima de ovos de boa qualidade e o equilíbrio alimentar das poedeiras. Dentre os principais componentes da ração para poedeiras na fase de postura destacam-se o milho (ou sorgo, utilizado por ter preço inferior em relação ao milho), em maior proporção, juntamente com farelo de soja, calcário, farelo de trigo, sal, farinha de carne, minerais e vitaminas. Todavia, as porcentagens dos insumos podem mudar com a fase de criação e respectivas necessidades energéticas. De acordo com Sobrinho e Fonseca (2007), a parte nutricional é um dos fatores que mais interferem no resultado produtivo do lote. Todo o programa alimentar de aves está baseado na função, idade e peso dos animais, assim os criadores devem fornecer uma ração especifica para cada período de desenvolvimento das aves.

Segundo Sobrinho e Fonseca (2007), entre os fatores que incidem no custo de produção por quilograma ou por dúzia de ovos, a ração é o item que entra em maior proporção, perfazendo $65 \%$ a $70 \%$ do custo total. Existe, portanto, uma constante preocupação por parte dos nutricionistas e de todos aqueles envolvidos 
na atividade avícola em elaborar dietas que propiciem excelente desempenho e, consequentemente, reduzam os custos de produção.

De acordo com Kakimoto et al. (2013), quanto aos insumos utilizados na ração, o valor do frete dos produtos proveniente de locais distantes tem sido considerado negativo pelos produtores de ovos e poderia ser melhorado, com o empenho do setor governamental, disponibilizando modais eficientes e melhorando a malha rodoviária nos estados produtores de grãos. A infraestrutura do setor de ovos é considerada positiva e contribui para o desenvolvimento do setor.

De acordo com Mizumoto (1996), nos primórdios da avicultura de postura brasileira, os criadores concentravam esforços no manejo e a cooperativa, figura presente na época, era fundamental no fornecimento de ração e na comercialização dos ovos. O desenvolvimento da tecnologia de fabricação de ração reduziu o investimento necessário para obter essas instalações e o avicultor obteve ganhos com a fabricação da ração de consumo interno (STEFANELLO, 2011).

A predominância de integração vertical dos processos produtivos de fabricação de ração e de processamento de ovos pelo avicultor é justificada pela alta incerteza da atividade de criação, tais como susceptibilidade a doenças, dificuldade de ajustes na oferta versus a demanda dado o longo ciclo da atividade, especificidade local e especificidade temporal. Martins (1996) afirma que a ausência de um modelo como o de contratos da avicultura de corte é justificada pela maior complexidade da atividade de postura, em que a qualidade do manejo tem caráter decisivo na atividade de longo prazo e que as oscilações de renda do avicultor exigem decisões que analisem um grande horizonte temporal.

De acordo com Hoffmann et al. (1992), para possibilitar o cálculo dos custos de produção é necessário fazer o inventário da propriedade no início e no fim do ano agrícola, deve-se manter um registro das despesas e da distribuição diária do trabalho entre as diferentes culturas e criações, trabalho não só dos assalariados como também dos membros da família, dos animais e do maquinário. Ainda de acordo com Hoffmann et al. (1992), o conhecimento sobre a distribuição do uso do trabalho e insumos possibilita a atualização do custo monetário através do tempo, desde que a tecnologia da produção se mantenha constante. Os dados necessários à determinação do custo devem ser coletados preferivelmente através dos registros financeiros e físicos da propriedade. Todavia, a grande maioria das propriedades agrícolas do Brasil ainda não possui registros físicos, e mesmo a contabilidade 
financeira, quando existe, nem sempre apresenta uma classificação de despesas num molde que facilite sua utilização. Não havendo registros, pode-se, de uma forma menos precisa, coletar os dados com auxílio de uma entrevista pessoal com o responsável pela exploração.

Raineri (2012) propôs uma metodologia para o levantamento dos custos de produção de cordeiros, na qual o esquema de alocação dos custos adotou como base a Teoria Econômica e diferentes métodos utilizados na agropecuária. Assim, em termos econômicos, os componentes do custo são agrupados nas categorias de custos variáveis, custos fixos, custo operacional e custo total, tal metodologia pode ser adequada para utilização na produção de ovos.

De acordo com Matsunaga et al. (1976), nos custos variáveis são agrupados todos os componentes que participam do processo à medida que a atividade produtiva se desenvolve, ou seja, aqueles que somente ocorrem ou incidem se houver produção, e que são diretamente relacionados, por exemplo, à quantidade de ovos produzidos. Nos custos fixos operacionais, enquadram-se os elementos de despesas que são suportados pelo produtor, independentemente do volume de produção, tais como mão de obra e depreciação das instalações e equipamentos. $O$ custo operacional é composto por todos os itens de custos variáveis e a parcela dos custos fixos diretamente associados à implementação da produção e, difere do custo total apenas por não contemplar a renda dos fatores, considerada como remuneração esperada sobre o capital e sobre a terra (MATSUNAGA et al., 1976).

Segundo Raineri (2012), a depreciação corresponde à reserva financeira necessária para que se possa adquirir um bem de mesmas características quando sua vida útil chegar ao fim devido ao desgaste pelo uso ou obsolescência normal. A renda dos fatores, no modelo proposto, é uma remuneração pelo uso do capital. Para ser calculada, uma taxa de juros deve ser utilizada para remunerar o capital de giro, o capital investido em ativos físicos e o uso da terra. O custo total de produção compreende o somatório do custo operacional mais a remuneração atribuída aos fatores de produção.

Sendo assim, devido à importância da atividade avícola para o País e para o Estado de São Paulo, estudos que avaliem os impactos socioeconômicos são necessários para introdução de novas políticas públicas, pois existe uma crença, ente os produtores, de que a adequação à IN 56, complementada pelas IN 59, IN 36 e IN 10, poderá ter um impacto significativo para a produção de ovos comerciais, 
pois, além das adequações da estrutura física e documental, deverá incentivar também uma mudança de comportamento do produtor diante das novas exigências. Os produtores deverão se adaptar a uma nova conduta de gestão da produção, lidar com os custos mais elevados de produção e com a aplicação de recursos financeiros, todos estes fatores poderão impactar a produção e, eventualmente, levar alguns granjeiros ao abandono da atividade. 


\section{MATERIAIS E MÉTODOS}

\subsection{Delimitação da pesquisa}

O levantamento dos estabelecimentos de postura comercial utilizadas para a execução desta pesquisa foi realizado junto ao Escritório de Defesa Agropecuária (EDA) de Limeira, da Coordenadoria de Defesa Agropecuária (CDA). De acordo com a Resolução SAA n 81 de 13 de dezembro de 2012, pertencem a Regional do EDA de Limeira os municípios de: Analândia, Araras, Cordeirópolis, Corumbataí, Ipeúna, Iracemápolis, Itirapina, Leme, Limeira, Pirassununga, Porto Ferreira, Rio Claro, Santa Cruz da Conceição e Santa Gertrudes (Figura 1) (SÃO PAULO, 2012).

Figura 1 - Regional Agropecuária de Limeira

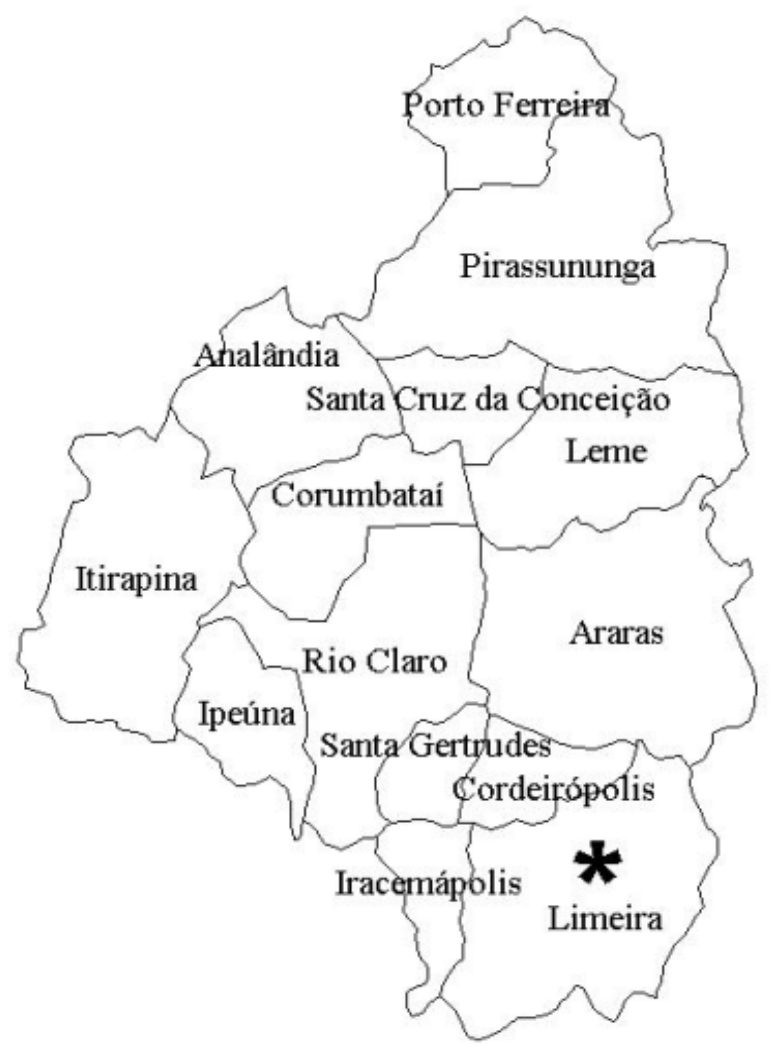

Fonte: Coordenadoria de Defesa Agropecuária do Estado de São Paulo. 
Segundo levantamento do autor, a regional agropecuária de Limeira é composta por 28 estabelecimentos avícolas comerciais de postura, com processo de registro no EDA Limeira, representando 5,3\% das granjas de postura do Estado de São Paulo e, correspondendo a 1,49\% do plantel estadual de poedeiras.

Em 04 de junho de 2013 foi realizado o "I Encontro dos Produtores de Ovos da Regional Agropecuária de Limeira" (Anexo A), no qual foram convidados todos os 28 estabelecimentos avícolas em processo de registro no Serviço Veterinário Oficial, Coordenadoria de Defesa Agropecuária, da circunscrição do EDA de Limeira. No evento foram abordados temas relativos às políticas sanitárias para estabelecimentos de produção de ovos, biosseguridade e apresentados os objetivos deste estudo socioeconômico referente aos impactos em atendimento às Instruções Normativas, convidando-os a participar voluntariamente da pesquisa.

Para a análise do perfil dos estabelecimentos avícolas comerciais de postura, foram utilizados dados de todos os 28 estabelecimentos em processo de registro na regional agropecuária de Limeira. A pesquisa foi de caráter exploratório. Para a análise do perfil do produtor e para a análise dos custos de produção foram levantados dados em dez estabelecimentos voluntários para participar da pesquisa, que ocorreu entre os meses de junho e julho de 2013. Nessas granjas foram realizadas visitas técnicas para o levantamento de dados, por meio da aplicação de questionário (Anexo B) e do preenchimento de uma planilha de custo (Anexo cdrom), desenvolvida especificamente para estimar os custos de produção de ovos e dos efeitos das novas medidas sobre o custo de produção.

\subsection{Levantamento de dados}

Foram utilizados dados primários e dados secundários. Os dados primários foram os obtidos a partir dos questionários, da documentação apresentada pelos produtores ao EDA Limeira na ocasião da solicitação de registro de estabelecimento avícola comercial e dos cálculos de custo de produção aplicados à amostra, por intermédio da pesquisa de campo. Os dados secundários foram obtidos por meio de 
referências bibliográficas, como livros, revistas, artigos, trabalhos acadêmicos e legislações.

Neste trabalho, o método utilizado para o estudo do tema, foi o "Survey", pois acredita-se que este seja o mais recomendado para explicar o objeto de estudo. Segundo Michel (2009), este método de pesquisa utiliza escalas de medidas cujo propósito é mensurar e quantificar opiniões e atitudes. Pode ser descrito como a obtenção de dados ou informações sobre características, ações ou opiniões de determinado grupo de pessoas, representantes de uma população pré-selecionada, por meio de um instrumento de pesquisa, normalmente um questionário (FREITAS et al., 2000). Para Babbie (1999), este método permite ao pesquisador examinar uma amostra da população facilitando uma análise quantitativa e ao mesmo tempo qualitativa dos dados coletados. A adoção desse tipo de pesquisa permite a elaboração clara e rigorosa de um modelo lógico, possibilitando ao pesquisador documentar processos causais mais complexos.

A amostra utilizada apresentou caráter não probabilístico. Segundo Vilela Junior (2007), neste tipo de pesquisa a amostra é definida pelo critério da similaridade, baseando-se em determinada característica. Desta forma, foi elaborado um questionário estruturado e semiaberto envolvendo dados quantitativos e qualitativos, visando atingir os objetivos propostos. O questionário envolveu questões como posse da terra, tamanho de propriedade, diversificação da propriedade, grau de conhecimento sobre a atividade, perfil socioeconômico, bemestar animal, entre outros.

O instrumento de pesquisa foi o método de entrevista face a face. Segundo Veiga e Gondim (2001), por serem discursivas, as entrevistas face a face apresentam como vantagem a possibilidade do entrevistado demonstrar sua linha de argumentação de forma a permitir que entrevistador associe-as, oferecendo assim oportunidades para identificação de opiniões, atitudes e valores do entrevistado.

De acordo com a metodologia para cálculo de custo de cordeiros, proposta por Raineri (2012), foi desenvolvida uma planilha, um simulador, no software Excel® (MICROSOFT, 2007), adaptada à atividade de postura, de modo a facilitar a utilização prática do modelo, seguindo também uma lógica que os criadores pudessem compreender e adotar, e ao mesmo tempo atendendo aos preceitos econômicos e zootécnicos para estimar os custos de produção. 
Deste modo, na planilha "Coeficientes Zootécnicos", foram inseridos os dados relativos aos coeficientes técnicos necessários à produção de ovos, ou seja, o período em que as aves se mantêm alojadas, em semanas, e o numero de aves alojadas. O programa calcula automaticamente a média de consumo de alimento e água para a estimativa dos custos. Também foram inseridos dados como: o número de galpões e seu tamanho, em metros quadrados; o numero de galpões monitorados para o Programa de Gestão de Risco Diferenciado; o tamanho da área destinada à atividade avícola na propriedade, em hectares; o tamanho da composteira em metros quadrados, assim como a quantidade de compostagem e esterco gerado pela atividade. Também foram incluídas a taxa média de produção de ovos e a taxa de mortalidade das aves no estabelecimento.

$\mathrm{Na}$ planilha "Preços", foram inseridos os dados econômicos relativos aos valores, em reais, dos fatores de produção envolvidos na atividade avícola de postura, incluindo as medidas de biosseguridade preconizadas pelas Instruções Normativas. Na planilha "Mão de Obra", foi inserido o valor, em porcentagem, dos encargos sociais sobre os salários pagos aos funcionários, informados na planilha "Preços".

$\mathrm{Na}$ planilha "Energia \& Água", foram inseridos os dados econômicos referentes ao uso de energia elétrica e motriz (trator), inclusive o tempo de uso destinado à avicultura e o consumo de combustível. Os consumidores de energia elétrica pagam um valor correspondente à quantidade de energia elétrica consumida, no mês anterior, estabelecida em quilowatt-hora (kWh) e multiplicada por um valor unitário (tarifa), medido em reais por quilowatt-hora ( $R \$ / k W h)$, que corresponde ao valor de 1quilowatt $(\mathrm{kW})$ consumido em uma hora (ANEEL, 2005). A estimativa dos custos com uso de energia elétrica, trator e combustível levou em consideração os valores informados nas planilhas, "Energia \& Água" e "Preços". O valor referente ao uso da água é estimado pelo valor informado para realização de todo o sistema hidráulico, incluindo a perfuração de poço e/ou captação de água, o uso de bomba e caixa d’água, o tratamento, a água servida às aves e pela utilização na limpeza das instalações, calculado pelo consumo em metros cúbicos pelo valor informado na planilha "Preços".

No caso dos insumos para produção e alimentos para o plantel, assumiu-se trabalhar apenas com os totais efetivamente consumidos pelas atividades produtivas. Desta forma, não foram considerados, para efeito de cálculo, eventuais 
estoques de insumos e/ou alimentos (SILVA et al., 2008). O preço dos insumos foi o praticado pelo mercado. Desta forma, na planilha "Fábrica de Ração", foram inseridos os dados relativos ao valor das instalações para a fabricação de ração, informada pelo produtor, e quanto da fabrica é destinada, em porcentagem, para a produção de ração das aves, no caso da fábrica servir para outras espécies. Também foi inserida a formulação da ração ofertada às aves, para que o programa possa calcular automaticamente o custo da ração por quilo, baseado no cálculo de consumo de alimento constante na planilha "Coeficientes Zootécnicos" e no período de alojamento, baseado nos valores dos insumos informado na planilha "Preços", para poder compor os custos de produção.

$\mathrm{Na}$ planilha "Produção de Ovos" foram inseridos os valores dos galpões e das instalações, estimado com base nos tamanho dos galpões em metros quadrados, informados na planilha "Coeficientes Zootécnicos" e nos valores de construção e dos equipamentos utilizados para a criação, informados na planilha "Preços". Em virtude da grande diferença entre os valores das instalações informados pelos produtores, foi adotado o valor de metade do indicado pelo CUB Custo Unitário Básico da Construção Civil para o Estado de São Paulo (SINDUSCON-SP, 2013), para a categoria de galpões industriais, somados ao valor de mercado das gaiolas, comedouros e bebedouros. Esta medida foi sugerida por Raineri (2012). O valor das aves utilizadas para a produção, sua depreciação e as perdas relativas a mortalidade, foi estimado pelo cálculo do numero de aves, período de alojamento, da taxa de mortalidade informadas na planilha "Coeficientes Zootécnicos" e pelo preço de aquisição das aves. O cálculo para a estimativa da produção de ovos considerou o período de alojamento, o número de aves e a taxa de produção informadas na planilha "Coeficientes Zootécnicos".

As medidas de biosseguridade exigidas pelas Instruções Normativas em análise, para composição do custo, na planilha "Sanidade \& Biosseguridade", foram: telagem dos galpões; cerca de isolamento; desinfecção de veículos (arcolúvio); composteira; limpeza e desinfecção dos galpões e das instalações; análise físicoquímica e microbiológica da água; controle de pragas e roedores; exames para isolamento e identificação de salmonelas e também da Responsabilidade Técnica (RT), por médico veterinário. O cálculo é automático e leva em consideração as informações das planilhas "Coeficientes Zootécnicos" e "Preços". Também é 
possível incluir o custo com vacinações e medicamentos utilizados na fase de produção.

Na planilha "Processamento e comércio", foram inseridos os dados relativos às instalações e equipamentos para a classificação e embalagem dos ovos, assim como as perdas com ovos quebrados, trincados e sujos, e dos valores recebido pela venda dos ovos. O número de ovos produzidos é representado pelo número de caixas de 30 dúzias efetivamente comercializadas no mês.

A última planilha, denominada de "Rentabilidade" consolida todas as informações relativas aos custos de produção por fator envolvido. São considerados a depreciação das instalações e equipamentos e os custos de oportunidade do capital, que foram diluídos pelos fatores envolvidos na produção, assim como o custo de oportunidade do arrendamento da terra. A planilha apresenta os valores dos custos por caixa de ovo e por unidade de ovo. Apresenta ainda, o quanto cada fator envolvido nos custos de produção representa em percentual. Também são consolidados os dados relativos ás receitas, desta forma o programa apresenta uma estimativa do resultado da atividade.

Deste modo, para a estimativa dos custos de produção e dos impactos das Instruções Normativas, foram simulados 4 (quatro) cenários diferentes, de modo que o cenário I (cenário base) apresenta a estimativa dos custos de produção, sem o atendimento às exigências da $I N n^{\circ} 56$, mas considerando todos os fatores de produção. O cenário II, inclui as exigências preconizadas pelas INs $n^{\circ} 56$ e $n^{\circ} 59$. $O$ cenário III, apresenta a estimativa de custo considerando as exigências das INs $n^{\circ}$ 36 e n' 10 , ou seja, sem a obrigatoriedade da instalação de tela e de acordo com o "Programa de Gestão de Risco Diferenciado". O cenário IV, apresenta a estimativa de custo considerando todas as INs, ou seja, incluindo a telagem do galpão e os exames de salmonelose. 


\section{RESULTADOS E DISCUSSÃO}

\subsection{Análise do perfil dos estabelecimentos avícolas comerciais de postura da regional agropecuária de Limeira}

Dentre os 14 municípios atendidos pela regional agropecuária de Limeira, sete possuem estabelecimentos avícolas comerciais de postura, que estão distribuídos entre os municípios de Cordeirópolis, Ipeúna, Itirapina, Leme, Limeira, Pirassununga e Santa Cruz da Conceição, totalizando 28 estabelecimentos em uma área superior a 52,5 hectares. As aves estão distribuídas em 135 galpões que ocupam $54.325 \mathrm{~m}^{2}$, com capacidade de alojamento para 538.500 aves, produzindo mais de 450 mil ovos por dia, envolvendo mais de 150 pessoas diretamente (Tabela 1). O município de Santa Cruz da Conceição é o maior produtor de ovos da regional, seguido pelos municípios de Pirassununga e Cordeirópolis.

Segundo Gewehr et al. (2010) não existe uma classificação oficial que determine se os estabelecimentos são de pequena, média ou grande escala. Assim, se os produtores de Santa Catarina (SC) que alojam até 15 mil aves (72\%) forem classificados como pequenos produtores, os que alojam entre 15 e 60 mil (24\%) como médios, e aqueles com mais de 60 mil aves (4\%) como grandes produtores, o número total de aves estaria distribuído em $20,2 \%$ no primeiro grupo, 45,3\% no segundo e $34,5 \%$ das aves entre os grandes produtores.

$\mathrm{Na}$ regional agropecuária de Limeira, Estado de São Paulo, utilizando o mesmo critério utilizado por Gewehr et al. (2010), os produtores que alojam até 15 mil aves (75\%), entre 15 e 60 mil aves (17,86\%) e acima de 60 mil aves $(7,14 \%)$ e o número total de aves estaria distribuído em $31,85 \%$ no primeiro grupo, $23,58 \%$ no segundo e 44,57\% no terceiro. Observa-se que os estabelecimentos que alojam até 15 mil aves são a maioria em SC e na regional agropecuária de Limeira, no entanto, SC concentra o maior número de aves no segundo grupo, estabelecimentos que alojam entre 15 e 60 mil aves, enquanto que na regional agropecuária de Limeira no terceiro grupo, estabelecimentos que alojam acima de 60 mil aves. 
De acordo com Gewehr et al. (2010), os estabelecimentos avícolas de Santa Catarina ficam a menos de dez $\mathrm{Km}$ de distância das sedes dos respectivos municípios, assim como os estabelecimentos avícolas de da regional agropecuária de Limeira, que também ficam a menos de dez $\mathrm{km}$ das sedes dos respectivos municípios. E, embora 30\% tenham considerado as vias de acesso às propriedades ruins, principalmente em períodos de chuva, parece não haver dificuldades para escoar a produção de ovos, pois, a malha viária que interliga os municípios da regional é asfaltada.

Ainda de acordo com Gewehr (2010), a maioria dos produtores fornece a sua produção de ovos a entrepostos regionais, não sendo diferente na regional agropecuária de Limeira, na qual sete produtores desempenham o papel de entreposto recebendo ovos dos produtores da região. O produtor não possui dificuldades para comercialização dos ovos. O mercado que absorve os ovos é regional, sendo Descalvado, São João da Boa Vista, Pirassununga e Santa Cruz da Conceição os principais consumidores e, a produção de ovos vermelhos supera a produção de ovos brancos, nenhuma das propriedades produz apenas ovos brancos. A recria é uma atividade desenvolvida em nove estabelecimentos e, embora criticada quanto ao bem estar animal, oito estabelecimentos realizam a muda forçada. 
Tabela 1 - Perfil dos estabelecimentos avícolas comerciais de postura da regional agropecuária de Limeira, Estado de São Paulo

\begin{tabular}{|c|c|c|c|c|c|c|c|}
\hline Município & $\begin{array}{c}\text { Estabelecimentos } \\
\text { Avícolas } \\
\text { (Granjas) } \\
\end{array}$ & $\begin{array}{l}\text { Área destinada à } \\
\text { atividade }(\mathrm{Ha})\end{array}$ & $\begin{array}{l}\text { Número de } \\
\text { Galpões }\end{array}$ & $\begin{array}{c}\text { Área dos } \\
\text { galpões }\left(\mathrm{m}^{2}\right)\end{array}$ & $\begin{array}{c}\text { Capacidade de } \\
\text { Alojamento (Aves) }\end{array}$ & $\begin{array}{l}\text { Produção } \\
\text { (Ovos/dia) }\end{array}$ & $\begin{array}{l}\text { Recursos } \\
\text { Humanos } \\
\text { (Pessoas) } \\
\end{array}$ \\
\hline Cordeirópolis & 2 & 5 & 15 & 9.445 & 125.000 & 106.250 & 25 \\
\hline Ipeúna & 1 & 2 & 1 & 1.460 & 10.000 & 8.500 & 5 \\
\hline Itirapina & 1 & 4,19 & 1 & 1.900 & 10.000 & 8.500 & 2 \\
\hline Leme & 1 & 0,2 & 6 & 1.310 & 7.200 & 6.120 & 5 \\
\hline Limeira & 1 & 4 & 3 & 4.730 & 30.000 & 25.500 & 3 \\
\hline Pirassununga & 13 & 13,4 & 51 & $12.984,97$ & 109.000 & 92.650 & 42 \\
\hline $\begin{array}{l}\text { Santa Cruz da } \\
\text { Conceição }\end{array}$ & 9 & 23,98 & 58 & $22.494,61$ & 247.300 & 210.205 & 68 \\
\hline TOTAL & 28 & 52,77 & 135 & $54.324,58$ & 538.500 & 457.725 & 150 \\
\hline
\end{tabular}

Fonte: Dados da pesquisa. 


\subsection{Análise do perfil socioeconômico do produtor}

Com exceção de dois dos 28 estabelecimentos, que são pessoas jurídicas, nos demais estabelecimentos os homens somam 23 produtores, representando $88,46 \%$, demonstrando a masculinização da propriedade familiar, corroborando com os dados de Belusso (2010), no qual os homens representaram 96,2\% das propriedades pesquisadas no oeste do Paraná.

Com relação ao tempo na atividade, 4 produtores desenvolvem a atividade avícola entre 5 a 10 anos: 8 produtores, entre 10 e 20 anos; 11, entre 20 e 30 anos; e 5, acima de 30 anos. Quanto à idade, apenas 1 produtor têm idade entre 25 e 40 anos, 9 produtores têm idade entre 40 e 55 anos e, a maioria, 12 produtores com idade entre 55 e 70 anos, assim como os dados encontrados por Belusso (2010), e acima dos 70 anos, 4 produtores. Essa média alta é consequência do processo que vem ocorrendo nos últimos 50 anos que Camarano e Abramovay (1999) ${ }^{1}$, apud Belusso (2010, p. 9), caracterizaram como "o envelhecimento e masculinização da população que vive no campo". Segundo os mesmos autores, são cada vez mais os jovens que abandonam o meio rural e entre estes se faz forte a participação das mulheres.

Com relação ao grau de escolaridade, verifica-se que 6 dos entrevistados não concluíram o $1^{\circ}$ grau, 2 concluíram o segundo grau e 2 possuem ensino superior completo. De acordo com Belusso (2010), essa característica pode ser um limitante para os produtores que ingressam em uma atividade como a avicultura, a qual possui um grau de tecnologia alto, e que periodicamente se depara com atualizações. Percebe se que nem todos os produtores absorvem a tecnologia da mesma forma, onde parte desses, geralmente associados à falta de estudo, veem a tecnologia como uma das principais dificuldades de atuar nesse mercado, outra relação que existe é o nível de escolaridade com a idade do produtor, onde quanto mais jovem, a tendência é que o produtor estenda seus estudos. Segundo os entrevistados, para os mais idosos, quando acessíveis, os estudos eram vistos como algo secundário.

\footnotetext{
${ }^{1}$ CAMARANO, A. A.; ABRAMOVAY, R. Êxodo Rural, envelhecimento e masculinização no Brasil: Panorama dos últimos 50 anos, p.7. IPEA, 1999.
} 
Quanto a situação financeira, 2 dos entrevistados relataram possuir algum tipo de dívida pessoal, sendo que 6 têm boas perspectivas quanto ao futuro da atividade e, embora 2 produtores tenham considerados as perspectivas para a atividade ruins, pretendem permanecer na mesma. Os produtores relatam ainda que não vivem exclusivamente da renda da atividade avícola, praticam a agricultura (grãos e cana de açúcar) e a bovinocultura de leite e corte como atividades secundárias, comércio na cidade ou casa de aluguel.

Todos os produtores residem em casa própria, sendo que metade reside na propriedade rural. Todos têm veículo de passeio. Todos os avicultores entrevistados possuem acesso à internet, ou tem alguém da família que acessa a rede mundial de computadores por ele. Em Santa Catarina, segundo Gewehr et al. (2010), apenas $45 \%$ dos produtores possuíam acesso a rede mundial de computadores.

Assim como os avicultores Catarinenses pesquisados por Gewehr et al. (2010), o avicultor da regional agropecuária de Limeira, de modo geral, possui informações sobre o mercado de ovos e gostaria de participar de eventos relacionados à avicultura, pois, acreditam que poderiam melhorar sua produção, tornando a atividade mais rentável. No entanto, alegam falta de tempo para participar, além do fato de muitas vezes não haver eventos na região.

Quando questionados quanto ao bem-estar das aves na produção, todos os produtores consideram importante essa questão e, embora esse conceito não esteja muito bem definido e difundido entre os criadores, 9 produtores enxergam as aves como "Fábrica de Ovos". Ainda quanto ao bem-estar animal, 7 produtores dizem ter conhecimento da Diretiva $n^{\circ} 74$ de 1999 da Comunidade Europeia, proibindo a criação de poedeiras no sistema de gaiolas em bateria. No entanto, 6 dos entrevistados são contra a criação de uma lei que regulamente o bem-estar em poedeiras e nenhum dos produtores adequaria voluntariamente suas instalações visando o bem estar das aves, a não ser que houvesse um "bônus" para esse produto. Todos conhecem outros sistemas de criação como em piso, ao ar livre e em gaiolas enriquecidas, a questão do bem-estar poderia ser considerado um diferencial para o produtor no mercado de ovos e sua inserção no mercado internacional.

Todos os produtores da regional agrícola de Limeira afirmaram terem conhecimento das Instruções Normativas n`56 de 2007, n`59 de 2009, n`36 de 2012 e $n^{\circ} 10$ de 2013, que estabelece os "Procedimentos para Registro, Fiscalização e Controle de Estabelecimentos Avícolas de Reprodução e Comerciais" e que 
estabelece o "Programa de Gestão de Risco Diferenciado"; 9 dos entrevistados afirmaram não possuir o dinheiro para realizar as adequações necessitando de financiamento. No entanto, 7 produtores acreditam que as adequações causarão algum impacto na atividade, como o abandono da atividade e, principalmente aumento do custo de produção, sendo que todos acreditam que o preço do ovo deverá aumentar para o consumidor. Porém, até a conclusão desta pesquisa, nenhum dos produtores entrevistados havia adequado suas instalações em atendimento às Instruções Normativas.

\subsection{Estimativa dos custos de produção ovos}

De acordo com a análise da tabela 2, o custo apresentado pelo produtor, subestimado por não considerar todos os fatores de produção, representou em média, $R \$ 46,67$ por caixa de ovo de 30 dúzias. Observa-se que o incremento entre o valor informado pelo produtor e os valores simulados para os cenários I, II, III e IV representaram em média 22,60\%, 24,94\%, 24,59\% e 25,21\% respectivamente.

Ainda de acordo com a análise da tabela 2 , quanto às adequações às Instruções Normativas $\mathrm{n}^{\circ} 56$ e, $\mathrm{n}^{\circ} 59$, cenário II, representou um incremento médio de 1,92\% sobre o custo de produção do "cenário base" (cenário I), enquanto que para o cenário III, na qual foi estimado o custo de produção considerando as Instruções Normativas no 36 e n 10, o incremento médio foi de 1,64\%. Quanto ao cenário IV, no qual foi considerado todas as exigências preconizadas pelas Instruções Normativas $n^{\circ} 56, n^{\circ} 59, n^{\circ} 36$ e $n^{\circ} 10$, o incremento foi de $2,14 \%$. Sendo que houve redução, do cenário II para o cenário III de 0,28 pontos percentuais (p.p.) e um incremento 0,22 p.p, do cenário II para o cenário IV. Entre o cenário III e o IV, o incremento foi de 0,5 p.p. 
Tabela 2 - Custo total estimado para a produção da caixa de ovo, por estabelecimento e cenário

\begin{tabular}{cccccc}
\hline ESTABELECIMENTO & $\begin{array}{c}\text { CUSTO } \\
\text { PRODUTOR }\end{array}$ & $\begin{array}{c}\text { CENÁRIO I } \\
\text { Base }\end{array}$ & CENÁRIO II & CENÁRIO III & CENÁRIO IV \\
\hline GRANJA 1 & $\mathrm{R} \$ 47,88$ & $\mathrm{R} \$ 61,01$ & $\mathrm{R} \$ 61,91$ & $\mathrm{R} \$ 61,68$ & $\mathrm{R} \$ 62,04$ \\
GRANJA 2 & $\mathrm{R} \$ 46,42$ & $\mathrm{R} \$ 57,36$ & $\mathrm{R} \$ 58,38$ & $\mathrm{R} \$ 58,15$ & $\mathrm{R} \$ 58,44$ \\
GRANJA 3 & $\mathrm{R} \$ 43,50$ & $\mathrm{R} \$ 54,44$ & $\mathrm{R} \$ 55,46$ & $\mathrm{R} \$ 55,23$ & $\mathrm{R} \$ 55,52$ \\
GRANJA 4 & $\mathrm{R} \$ 39,86$ & $\mathrm{R} \$ 48,98$ & $\mathrm{R} \$ 49,99$ & $\mathrm{R} \$ 49,98$ & $\mathrm{R} \$ 50,24$ \\
GRANJA 5 & $\mathrm{R} \$ 51,98$ & $\mathrm{R} \$ 65,61$ & $\mathrm{R} \$ 66,58$ & $\mathrm{R} \$ 66,40$ & $\mathrm{R} \$ 66,72$ \\
GRANJA 6 & $\mathrm{R} \$ 46,77$ & $\mathrm{R} \$ 54,29$ & $\mathrm{R} \$ 55,14$ & $\mathrm{R} \$ 55,00$ & $\mathrm{R} \$ 55,20$ \\
GRANJA 7 & $\mathrm{R} \$ 44,44$ & $\mathrm{R} \$ 55,71$ & $\mathrm{R} \$ 56,91$ & $\mathrm{R} \$ 56,76$ & $\mathrm{R} \$ 57,01$ \\
GRANJA 8 & $\mathrm{R} \$ 53,59$ & $\mathrm{R} \$ 60,23$ & $\mathrm{R} \$ 62,23$ & $\mathrm{R} \$ 62,04$ & $\mathrm{R} \$ 62,38$ \\
GRANJA 9 & $\mathrm{R} \$ 41,93$ & $\mathrm{R} \$ 52,14$ & $\mathrm{R} \$ 53,10$ & $\mathrm{R} \$ 53,00$ & $\mathrm{R} \$ 53,25$ \\
GRANJA 10 & $\mathrm{R} \$ 50,39$ & $\mathrm{R} \$ 61,76$ & $\mathrm{R} \$ 62,80$ & $\mathrm{R} \$ 62,61$ & $\mathrm{R} \$ 62,91$ \\
\hline MÉDIA & $\mathbf{R} \$ \mathbf{4 6 , 6 7}$ & $\mathbf{R} \$ \mathbf{5 7 , 1 5}$ & $\mathbf{R} \$ \mathbf{5 8 , 2 5}$ & $\mathbf{R} \$ \mathbf{5 8 , 0 9}$ & $\mathbf{R} \$ \mathbf{5 8 , 3 7}$ \\
MíNIMO & $\mathbf{R} \$ \mathbf{3 9 , 8 6}$ & $\mathbf{R} \$ \mathbf{4 8 , 9 8}$ & $\mathbf{R} \$ \mathbf{4 9 , 9 9}$ & $\mathbf{R} \$ \mathbf{4 9 , 9 8}$ & $\mathbf{R} \$ \mathbf{5 0 , 2 4}$ \\
MÁXIMO & $\mathbf{R} \$ \mathbf{5 3 , 5 9}$ & $\mathbf{R} \$ \mathbf{6 5 , 6 1}$ & $\mathbf{R} \$ \mathbf{6 6 , 5 8}$ & $\mathbf{R} \$ \mathbf{6 6 , 4 0}$ & $\mathbf{R} \$ \mathbf{6 6 , 7 2}$ \\
VARIAÇÃO PRODUTOR & - & $\mathbf{2 2 , 6 \%}$ & $\mathbf{2 4 , 9 4 \%}$ & $\mathbf{2 4 , 5 9 \%}$ & $\mathbf{2 5 , 2 1 \%}$ \\
VARIAÇÃO CENÁRIO I & - & - & $\mathbf{1 , 9 2 \%}$ & $\mathbf{1 , 6 4 \%}$ & $\mathbf{2 , 1 4 \%}$ \\
\hline
\end{tabular}

Fonte: Dados da pesquisa. 
De acordo com a tabela 3, o custo de produção estimado no cenário I, sem as exigências preconizadas pelas Instruções Normativas, representou em média, $R$ \$ 57,15 por caixa de ovo com 30 dúzias. Ainda de acordo com a mesma tabela, quanto aos custos de produção com relação à mão de obra, alguns estabelecimentos utilizam mão de obra familiar sendo o seu pró-labore condicionado ao resultado da atividade no mês, desta forma só foram contabilizados os custos relativos a mão de obra nos estabelecimentos que possuem funcionário fixo, esse custo, representou em média $3,58 \%$ do custo de produção.

Os custos envolvidos para a geração de energia e fornecimento de água corresponderam em média a $2,78 \%$ do custo de produção. A ração é o item que entra em maior proporção entre os fatores que incidem no custo de produção, perfazendo $60,87 \%$ do custo total.

Embora a atividade de recria possa significar uma redução nos custos, para efeito de cálculo do custo de produção foi considerado o valor de mercado da galinha recriada, ou seja, pronta para postura. Ao final do primeiro ciclo, as aves relacionadas, ainda possuem mais um período de produção, mediante a muda forçada, os produtores relatam que tal procedimento ocorre em função do preço de aquisição de novas aves no mercado e da qualidade em que as aves se encontram para suportar um novo ciclo. Quando as aves forem descartadas, entram como receita, assim como a venda do esterco e compostagem para adubo. Pode-se conseguir um pequeno valor, o qual pode ser utilizado para compra de novas aves. Desta forma, os fatores vinculados à produção, como a aquisição das aves, instalações e equipamentos, depreciação e custo de oportunidade do capital, representaram o segundo maior peso no custo de produção, correspondendo a $25,40 \%$ do custo total.

Alguns produtores desempenham também o papel de entreposto, no entanto, para mensurar o custo de produção de ovos, com relação aos custos de processamento e comércio, foi levado em consideração, o valor pago pelo entreposto ao produtor, em média o produtor recebeu do entreposto, na época, o equivalente a $R \$ 65,00$ por caixa com 30 dúzias de ovos, de modo que 0 processamento dos ovos representou $6,78 \%$ do custo total. Já, o custo de oportunidade do arrendamento da terra, baseado no valor pago pela cultura da cana de açúcar, foi o fator com o valor mais baixo, representando 0,59\% do custo total. 
As diferenças encontradas entre as estimativas de custo de produção por granja e, considerando os diferentes cenários propostos, devem-se a eficiência ou ineficiência técnica de alguns granjeiros. Também pode-se atribuir tal resultado pelo fato de muitos dos produtores adotarem a mão de obra familiar como citado anteriormente e, o custo dessa mão de obra não foi contabilizado. Ainda, pode-se atribuir o alto custo dos insumos utilizados na alimentação e que sofrem diversas alterações de preço e qualidade ao longo do ano, influenciando diretamente a eficiência econômica e técnica da atividade. Deve-se considerar também que cooperativas, associações ou, simplesmente, grupos de compras, podem influenciar de maneira positiva na redução dos custos para a aquisição de insumos e serviços. 
Tabela 3 - Custo total de produção da caixa de ovo por estabelecimento e fatores envolvidos, em porcentagem (Cenário I)

\begin{tabular}{|c|c|c|c|c|c|c|c|}
\hline Estabelecimento & Custo Total & Mão de Obra & $\begin{array}{c}\text { Energia e } \\
\text { Água }\end{array}$ & $\begin{array}{c}\text { Fábrica } \\
\text { de Ração }\end{array}$ & $\begin{array}{c}\text { Produção } \\
\text { de ovos }\end{array}$ & $\begin{array}{c}\text { Processamento } \\
\text { e Comércio }\end{array}$ & Terra \\
\hline GRANJA 1 & $\mathrm{R} \$ 61,01$ & $0,00 \%$ & $1,63 \%$ & $62,76 \%$ & $27,87 \%$ & $7,67 \%$ & $0,06 \%$ \\
\hline GRANJA 2 & $\mathrm{R} \$ 57,36$ & $5,09 \%$ & $2,88 \%$ & $59,17 \%$ & $25,84 \%$ & $6,79 \%$ & $0,23 \%$ \\
\hline GRANJA 3 & $\mathrm{R} \$ 54,44$ & $0,00 \%$ & $3,04 \%$ & $62,34 \%$ & $27,23 \%$ & $7,15 \%$ & $0,24 \%$ \\
\hline GRANJA 4 & $\mathrm{R} \$ 48,98$ & $0,00 \%$ & $2,33 \%$ & $64,03 \%$ & $26,85 \%$ & $6,44 \%$ & $0,35 \%$ \\
\hline GRANJA 5 & $\mathrm{R} \$ 65,61$ & $6,63 \%$ & $3,13 \%$ & $56,24 \%$ & $23,86 \%$ & $10,03 \%$ & $0,12 \%$ \\
\hline GRANJA 6 & $\mathrm{R} \$ 54,29$ & $5,49 \%$ & $1,98 \%$ & $64,87 \%$ & $20,96 \%$ & $5,77 \%$ & $0,92 \%$ \\
\hline GRANJA 7 & $\mathrm{R} \$ 55,71$ & $6,40 \%$ & $3,94 \%$ & $56,46 \%$ & $23,28 \%$ & $8,78 \%$ & $1,15 \%$ \\
\hline GRANJA 8 & $\mathrm{R} \$ 60,23$ & $2,50 \%$ & $3,51 \%$ & $60,08 \%$ & $28,17 \%$ & $3,60 \%$ & $2,14 \%$ \\
\hline GRANJA 9 & $\mathrm{R} \$ 52,15$ & $0,00 \%$ & $2,37 \%$ & $64,93 \%$ & $24,51 \%$ & $7,66 \%$ & $0,53 \%$ \\
\hline GRANJA 10 & $\mathrm{R} \$ 61,76$ & $9,72 \%$ & $2,97 \%$ & $57,82 \%$ & $25,42 \%$ & $3,88 \%$ & $0,20 \%$ \\
\hline MÉDIA & $\mathrm{R} \$ 57,15$ & $3,58 \%$ & $2,78 \%$ & $60,87 \%$ & $25,40 \%$ & $6,78 \%$ & $0,59 \%$ \\
\hline
\end{tabular}

Fonte: Dados da pesquisa. 


\subsection{Impactos das instruções normativas sobre os custos de produção de ovos}

As medidas de biosseguridade exigidas pelas Instruções Normativas em análise, para composição do custo, foram: telagem dos galpões; cerca de isolamento; desinfecção de veículos (arcolúvio); composteira; limpeza e desinfecção dos galpões e das instalações; análise físico-química e microbiológica da água; controle de pragas e roedores; exames para isolamento e identificação de salmonelas e também da Responsabilidade Técnica (RT), por médico veterinário.

Deste modo, os custos com a sanidade e a biosseguridade, ou seja, às adequações às Instruções Normativas, conforme simulado para os Cenários II (Tabela 4), III (Tabela 6) e IV (Tabela 8), corresponderam, respectivamente a 1,89\%, $1,61 \%$ e $2,09 \%$ do custo total de produção. As estimativas dos custos para implantação das medidas de biosseguridade exigidas pelas Instruções Normativas, para a simulação dos cenários II, III e IV, estão representadas, respectivamente, nas tabelas 5,7 e 9 .

A tabela 10 apresenta um comparativo com os custos de adequação entre os diferentes cenários. Pode-se observar que o custo de produção demonstrado no cenário III, no qual substitui-se a tela pelo exame de salmonela, aparentemente representa um custo menor para o produtor, porém, neste estudo não foram contabilizados os custos referentes às ações sobre os estabelecimentos que apresentarem exame positivo para salmonela, como os custos com exames complementares, tratamento das aves e o destino da produção de ovos provenientes de aves positivas, assim como o descarte dessas aves.

Os incrementos no custo de produção entre os Cenários II, III e IV, representaram entre 0,28 p.p. a 0,5 p.p. Em virtude do risco sanitário e dos possíveis prejuízos que tais riscos representam para o setor, sugere-se o retorno da tela conforme preconizado na IN n 56 de 2007, associada a um programa de vigilância epidemiológica e sanitária. Pois, de acordo com a experiência mexicana, o surto de Influenza Aviária trouxe enormes prejuízos ao setor de produção de aves, ovos férteis e ovos.

De acordo com Sherwell e Sawyer (2013), a aplicação de medidas de biosseguridade para isolar o vírus no surto mexicano, tornou a produção mais 
onerosa, com aumento médio de $10 \%$ no preço das aves e de ovos férteis. Os mesmos autores acreditam que tanto o consumo de ovos quanto o de carne devam crescer, mas, em um ritmo mais lento. Os mesmos autores consideram que 0 México deve deixar de ser exportador e passar a ser importador de ovos, pois, é o maior consumidor de ovos do mundo, embora seu consumo tenha diminuído em $7,1 \%$.

Ainda de acordo com Sherwell e Sawyer (2013), entre o primeiro surto em 2012 e último surto em 2013, o preço dos ovos aumentou em média $73 \%$. O preço encontrou apoio na queda de produção e nas importações, que não foram capazes de suprir a demanda. O preço da carne de frango também teve um aumento médio de $30 \%$, em razão do aumento do preço dos ovos férteis e pela diminuição do rebanho. Espera-se um aumento no consumo de ovos industrializados, importados dos EUA. Principal exportador de carne de frango para o México, o surto de Influenza Aviária beneficiou a industria avícola dos EUA, que espera um aumento de $15 \%$ nas exportações de carne de frango, enquanto que para as exportações de ovos in natura e industrializados, o potencial de crescimento é de até $500 \%$ e $200 \%$, respectivamente. 
Tabela 4 - Custo total de produção da caixa do ovo por estabelecimento, considerando as exigências preconizadas pelas INs $n^{\circ} 56$ e n 59 (Cenário II)

\begin{tabular}{|c|c|c|c|c|c|c|c|c|}
\hline Estabelecimento & Custo Total & $\begin{array}{c}\text { Sanidade e } \\
\text { Biosseguridade }\end{array}$ & $\begin{array}{l}\text { Mão } \\
\text { Obra } \\
\end{array}$ & $\begin{array}{l}\text { Energia } \\
\text { e Água }\end{array}$ & $\begin{array}{c}\text { Fábrica } \\
\text { de Ração }\end{array}$ & $\begin{array}{l}\text { Produção } \\
\text { de ovos }\end{array}$ & $\begin{array}{l}\text { Processamento } \\
\text { e Comércio }\end{array}$ & Terra \\
\hline GRANJA 2 & $\mathrm{R} \$ 58,38$ & $1,74 \%$ & $5,00 \%$ & $2,83 \%$ & $58,14 \%$ & $25,39 \%$ & $6,67 \%$ & $0,22 \%$ \\
\hline GRANJA 3 & $\mathrm{R} \$ 55,46$ & $1,84 \%$ & $0,00 \%$ & $2,98 \%$ & $61,20 \%$ & $26,73 \%$ & $7,02 \%$ & $0,23 \%$ \\
\hline GRANJA 4 & $\mathrm{R} \$ 49,99$ & $2,03 \%$ & $0,00 \%$ & $2,28 \%$ & $62,73 \%$ & $26,31 \%$ & $6,31 \%$ & $0,34 \%$ \\
\hline GRANJA 7 & $\mathrm{R} \$ 56,91$ & $2,12 \%$ & $6,26 \%$ & $3,85 \%$ & $55,26 \%$ & $22,79 \%$ & $8,59 \%$ & $1,13 \%$ \\
\hline GRANJA 8 & $\mathrm{R} \$ 62,23$ & $3,22 \%$ & $2,42 \%$ & $3,40 \%$ & $58,15 \%$ & $27,26 \%$ & $3,48 \%$ & $2,07 \%$ \\
\hline GRANJA 9 & $\mathrm{R} \$ 53,10$ & $1,80 \%$ & $0,00 \%$ & $2,33 \%$ & $63,76 \%$ & $24,07 \%$ & $7,52 \%$ & $0,52 \%$ \\
\hline GRANJA 10 & $\mathrm{R} \$ 62,80$ & $1,65 \%$ & $9,55 \%$ & $2,92 \%$ & $56,87 \%$ & $24,99 \%$ & $3,81 \%$ & $0,20 \%$ \\
\hline
\end{tabular}

Fonte: Dados da pesquisa 
Tabela 5 - Distribuição do custo dos fatores envolvidos no custo total da biosseguridade, considerando as exigências preconizadas pelas INs $n^{\circ} 56$ e $n^{\circ} 59$ (Cenário II)

\begin{tabular}{ccccccccc}
\hline Estabelecimento & RT & Tela & $\begin{array}{c}\text { Cerca de } \\
\text { Isolamento }\end{array}$ & $\begin{array}{c}\text { Limpeza e } \\
\text { Desinfecção }\end{array}$ & $\begin{array}{c}\text { Arco de } \\
\text { Desinfecção }\end{array}$ & Composteira & $\begin{array}{c}\text { Controle } \\
\text { de Pragas e } \\
\text { Roedores }\end{array}$ & $\begin{array}{c}\text { Análise } \\
\text { de Água }\end{array}$ \\
\hline GRANJA 1 & $50,45 \%$ & $25,82 \%$ & $2,27 \%$ & $9,93 \%$ & $4,73 \%$ & $2,73 \%$ & $3,28 \%$ & $0,80 \%$ \\
GRANJA 2 & $54,77 \%$ & $17,86 \%$ & $6,63 \%$ & $8,84 \%$ & $5,52 \%$ & $3,18 \%$ & $2,27 \%$ & $0,93 \%$ \\
GRANJA 3 & $54,77 \%$ & $17,86 \%$ & $6,63 \%$ & $8,84 \%$ & $5,52 \%$ & $3,18 \%$ & $2,27 \%$ & $0,93 \%$ \\
GRANJA 4 & $50,42 \%$ & $16,27 \%$ & $9,15 \%$ & $8,79 \%$ & $7,62 \%$ & $4,39 \%$ & $2,07 \%$ & $1,29 \%$ \\
GRANJA 5 & $56,13 \%$ & $19,92 \%$ & $4,04 \%$ & $10,04 \%$ & $4,21 \%$ & $2,43 \%$ & $2,53 \%$ & $0,71 \%$ \\
GRANJA 6 & $24,46 \%$ & $18,05 \%$ & $39,27 \%$ & $9,45 \%$ & $1,60 \%$ & $3,68 \%$ & $2,30 \%$ & $0,28 \%$ \\
GRANJA 7 & $36,47 \%$ & $15,15 \%$ & $32,82 \%$ & $8,34 \%$ & $2,28 \%$ & $2,63 \%$ & $1,92 \%$ & $0,38 \%$ \\
GRANJA 8 & $30,97 \%$ & $13,12 \%$ & $41,82 \%$ & $7,35 \%$ & $2,90 \%$ & $1,67 \%$ & $1,67 \%$ & $0,49 \%$ \\
GRANJA 9 & $49,47 \%$ & $16,80 \%$ & $16,03 \%$ & $8,02 \%$ & $3,71 \%$ & $3,21 \%$ & $2,13 \%$ & $0,63 \%$ \\
GRANJA 10 & $60,82 \%$ & $17,05 \%$ & $5,89 \%$ & $9,10 \%$ & $2,45 \%$ & $2,12 \%$ & $2,16 \%$ & $0,41 \%$ \\
MÉDIA & $\mathbf{4 6 , 8 7 \%}$ & $\mathbf{1 7 , 8 0} \%$ & $\mathbf{1 6 , 4 5 \%}$ & $\mathbf{8 , 8 7} \%$ & $\mathbf{4 , 0 5 \%}$ & $\mathbf{2 , 9 2 \%}$ & $\mathbf{2 , 2 6 \%}$ & $\mathbf{0 , 6 8 \%}$ \\
\hline
\end{tabular}

Fonte: Dados da pesquisa 
Tabela 6 - Custo total de produção da caixa do ovo por estabelecimento, considerando as exigências preconizadas pelas INs $n^{\circ} 36$ e n 10 (Cenário III)

\begin{tabular}{|c|c|c|c|c|c|c|c|c|}
\hline Estabelecimento & Custo Total & $\begin{array}{c}\text { Sanidade e } \\
\text { Biosseguridade }\end{array}$ & $\begin{array}{l}\text { Mão } \\
\text { Obra }\end{array}$ & $\begin{array}{l}\text { Energia } \\
\text { e Água }\end{array}$ & $\begin{array}{c}\text { Fábrica } \\
\text { de Ração }\end{array}$ & $\begin{array}{c}\text { Produção } \\
\text { de ovos }\end{array}$ & $\begin{array}{c}\text { Processamento } \\
\text { e Comércio }\end{array}$ & Terra \\
\hline GRANJA 1 & $\mathrm{R} \$ 61,68$ & $1,09 \%$ & $0,00 \%$ & $1,61 \%$ & $62,08 \%$ & $27,57 \%$ & $7,59 \%$ & $0,06 \%$ \\
\hline GRANJA 2 & $\mathrm{R} \$ 58,15$ & $1,35 \%$ & $5,02 \%$ & $2,84 \%$ & $58,37 \%$ & $25,49 \%$ & $6,70 \%$ & $0,22 \%$ \\
\hline GRANJA 3 & $\mathrm{R} \$ 55,23$ & $1,42 \%$ & $0,00 \%$ & $2,99 \%$ & $61,46 \%$ & $26,84 \%$ & $7,05 \%$ & $0,23 \%$ \\
\hline GRANJA 4 & $\mathrm{R} \$ 49,98$ & $2,01 \%$ & $0,00 \%$ & $2,28 \%$ & $62,74 \%$ & $26,31 \%$ & $6,31 \%$ & $0,34 \%$ \\
\hline GRANJA 5 & $\mathrm{R} \$ 66,40$ & $1,19 \%$ & $6,55 \%$ & $3,09 \%$ & $55,57 \%$ & $23,57 \%$ & $9,91 \%$ & $0,12 \%$ \\
\hline GRANJA 6 & $\mathrm{R} \$ 55,00$ & $1,30 \%$ & $5,42 \%$ & $1,96 \%$ & $64,03 \%$ & $20,68 \%$ & $5,70 \%$ & $0,91 \%$ \\
\hline GRANJA 7 & $\mathrm{R} \$ 56,76$ & $1,86 \%$ & $6,28 \%$ & $3,86 \%$ & $55,41 \%$ & $22,85 \%$ & $8,61 \%$ & $1,13 \%$ \\
\hline GRANJA 8 & $\mathrm{R} \$ 62,04$ & $2,92 \%$ & $2,43 \%$ & $3,41 \%$ & $58,33 \%$ & $27,35 \%$ & $3,49 \%$ & $2,08 \%$ \\
\hline GRANJA 9 & $R \$ 53,00$ & $1,62 \%$ & $0,00 \%$ & $2,33 \%$ & $63,87 \%$ & $24,11 \%$ & $7,54 \%$ & $0,52 \%$ \\
\hline GRANJA 10 & $\mathrm{R} \$ 62,61$ & $1,37 \%$ & $9,58 \%$ & $2,93 \%$ & $57,03 \%$ & $25,07 \%$ & $3,82 \%$ & $0,20 \%$ \\
\hline MÉDIA & $\mathbf{R} \$ 58,09$ & $1,61 \%$ & $3,53 \%$ & $2,73 \%$ & $59,89 \%$ & $24,98 \%$ & $6,67 \%$ & $0,58 \%$ \\
\hline
\end{tabular}

Fonte: Dados da pesquisa 
Tabela 7- Distribuição do custo dos fatores envolvidos no custo total da biosseguridade, considerando as exigências preconizadas pelas INs $n^{\circ} 36$ e $n^{\circ} 10$ (Cenário III).

\begin{tabular}{|c|c|c|c|c|c|c|c|c|}
\hline Estabelecimento & $\mathbf{R T}$ & $\begin{array}{l}\text { Exame de } \\
\text { Salmonela }\end{array}$ & $\begin{array}{l}\text { Cerca de } \\
\text { Isolamento }\end{array}$ & $\begin{array}{c}\text { Limpeza e } \\
\text { Desinfecção }\end{array}$ & $\begin{array}{c}\text { Arco de } \\
\text { Desinfecção }\end{array}$ & Composteira & $\begin{array}{c}\text { Controle } \\
\text { de Pragas e } \\
\text { Roedores }\end{array}$ & $\begin{array}{l}\text { Análise } \\
\text { de Água }\end{array}$ \\
\hline GRANJA 1 & $52,27 \%$ & $23,15 \%$ & $2,35 \%$ & $10,28 \%$ & $4,90 \%$ & $2,82 \%$ & $3,40 \%$ & $0,83 \%$ \\
\hline GRANJA 2 & $60,30 \%$ & $9,57 \%$ & $7,29 \%$ & $9,73 \%$ & $6,08 \%$ & $3,50 \%$ & $2,50 \%$ & $1,03 \%$ \\
\hline GRANJA 3 & $60,30 \%$ & $9,57 \%$ & $7,29 \%$ & $9,73 \%$ & $6,08 \%$ & $3,50 \%$ & $2,50 \%$ & $1,03 \%$ \\
\hline GRANJA 4 & $42,11 \%$ & $30,08 \%$ & $7,64 \%$ & $7,34 \%$ & $6,37 \%$ & $3,67 \%$ & $1,72 \%$ & $1,08 \%$ \\
\hline GRANJA 5 & $56,15 \%$ & $19,89 \%$ & $4,04 \%$ & $10,04 \%$ & $4,21 \%$ & $2,43 \%$ & $2,53 \%$ & $0,71 \%$ \\
\hline GRANJA 6 & $26,94 \%$ & $13,26 \%$ & $41,54 \%$ & $9,99 \%$ & $1,68 \%$ & $3,88 \%$ & $2,42 \%$ & $0,28 \%$ \\
\hline GRANJA 7 & $36,76 \%$ & $14,47 \%$ & $33,09 \%$ & $8,41 \%$ & $2,30 \%$ & $2,65 \%$ & $1,94 \%$ & $0,39 \%$ \\
\hline GRANJA 8 & $30,79 \%$ & $13,64 \%$ & $41,57 \%$ & $7,31 \%$ & $2,89 \%$ & $1,66 \%$ & $1,66 \%$ & $0,49 \%$ \\
\hline GRANJA 9 & $46,42 \%$ & $21,93 \%$ & $15,04 \%$ & $7,53 \%$ & $3,48 \%$ & $3,01 \%$ & $2,00 \%$ & $0,59 \%$ \\
\hline GRANJA 10 & $61,81 \%$ & $15,70 \%$ & $5,98 \%$ & $9,25 \%$ & $2,49 \%$ & $2,15 \%$ & $2,20 \%$ & $0,42 \%$ \\
\hline MÉDIA & $47,39 \%$ & $17,13 \%$ & $16,58 \%$ & $8,96 \%$ & $4,05 \%$ & $2,93 \%$ & $2,29 \%$ & $0,69 \%$ \\
\hline
\end{tabular}

Fonte: Dados da pesquisa 
Tabela 8 - Custo total de produção da caixa do ovo por estabelecimento, considerando as exigências preconizadas pelas INs $n^{\circ} 56, n^{\circ} 59, n^{\circ} 36$ e $n^{\circ} 10$ (Cenário IV)

\begin{tabular}{|c|c|c|c|c|c|c|c|c|}
\hline Estabelecimento & Custo Total & $\begin{array}{c}\text { Sanidade e } \\
\text { Biosseguridade }\end{array}$ & $\begin{array}{l}\text { Mão } \\
\text { Obra }\end{array}$ & $\begin{array}{l}\text { Energia } \\
\text { e Água }\end{array}$ & $\begin{array}{c}\text { Fábrica } \\
\text { de Ração }\end{array}$ & $\begin{array}{l}\text { Produção } \\
\text { de ovos }\end{array}$ & $\begin{array}{c}\text { Processamento } \\
\text { e Comércio }\end{array}$ & Terra \\
\hline GRANJA 1 & $\mathrm{R} \$ 62,04$ & $1,67 \%$ & $0,00 \%$ & $1,60 \%$ & $61,71 \%$ & $27,41 \%$ & $7,54 \%$ & $0,06 \%$ \\
\hline GRANJA 2 & $\mathrm{R} \$ 58,44$ & $1,85 \%$ & $4,99 \%$ & $2,83 \%$ & $58,08 \%$ & $25,37 \%$ & $6,66 \%$ & $0,22 \%$ \\
\hline GRANJA 3 & $\mathrm{R} \$ 55,52$ & $1,94 \%$ & $0,00 \%$ & $2,98 \%$ & $61,13 \%$ & $26,70 \%$ & $7,01 \%$ & $0,23 \%$ \\
\hline GRANJA 4 & $\mathrm{R} \$ 50,24$ & $2,51 \%$ & $0,00 \%$ & $2,27 \%$ & $62,42 \%$ & $26,18 \%$ & $6,28 \%$ & $0,34 \%$ \\
\hline GRANJA 5 & $\mathrm{R} \$ 66,72$ & $1,66 \%$ & $6,52 \%$ & $3,08 \%$ & $55,30 \%$ & $23,46 \%$ & $9,86 \%$ & $0,12 \%$ \\
\hline GRANJA 6 & $\mathrm{R} \$ 55,20$ & $1,64 \%$ & $5,40 \%$ & $1,95 \%$ & $63,80 \%$ & $20,61 \%$ & $5,68 \%$ & $0,91 \%$ \\
\hline GRANJA 7 & $\mathrm{R} \$ 57,02$ & $2,29 \%$ & $6,25 \%$ & $3,85 \%$ & $55,16 \%$ & $22,75 \%$ & $8,57 \%$ & $1,12 \%$ \\
\hline GRANJA 8 & $\mathrm{R} \$ 62,38$ & $3,45 \%$ & $2,41 \%$ & $3,39 \%$ & $58,01 \%$ & $27,20 \%$ & $3,47 \%$ & $2,07 \%$ \\
\hline GRANJA 9 & $\mathrm{R} \$ 53,25$ & $2,07 \%$ & $0,00 \%$ & $2,32 \%$ & $63,58 \%$ & $24,00 \%$ & $7,50 \%$ & $0,52 \%$ \\
\hline GRANJA 10 & $\mathrm{R} \$ 62,91$ & $1,84 \%$ & $9,54 \%$ & $2,92 \%$ & $56,76 \%$ & $24,95 \%$ & $3,81 \%$ & $0,20 \%$ \\
\hline MÉDIA & $\mathbf{R} \$ 58,37$ & $2,09 \%$ & $3,51 \%$ & $2,72 \%$ & $59,60 \%$ & $24,86 \%$ & $6,64 \%$ & $0,58 \%$ \\
\hline
\end{tabular}

Fonte: Dados da pesquisa 
Tabela 9 - Distribuição do custo dos fatores envolvidos no custo total da biosseguridade, considerando as exigências preconizadas pelas 1 INs $n^{\circ} 56, n^{\circ} 59, n^{\circ}$ 36 e no 10 (Cenário IV)

\begin{tabular}{|c|c|c|c|c|c|c|c|c|c|}
\hline Estabelecimento & RT & Tela & $\begin{array}{l}\text { Exame de } \\
\text { Salmonela }\end{array}$ & $\begin{array}{l}\text { Cerca de } \\
\text { Isolamento }\end{array}$ & $\begin{array}{c}\text { Limpeza e } \\
\text { Desinfecção }\end{array}$ & $\begin{array}{c}\text { Arco de } \\
\text { Desinfecção }\end{array}$ & Composteira & $\begin{array}{c}\text { Controle } \\
\text { de Pragas e } \\
\text { Roedores } \\
\end{array}$ & $\begin{array}{l}\text { Análise } \\
\text { de Água }\end{array}$ \\
\hline GRANJA 1 & $41,24 \%$ & $21,11 \%$ & $18,26 \%$ & $1,86 \%$ & $8,11 \%$ & $3,87 \%$ & $2,23 \%$ & $2,68 \%$ & $0,65 \%$ \\
\hline GRANJA 3 & $50,39 \%$ & $16,43 \%$ & $8,00 \%$ & $6,10 \%$ & $8,13 \%$ & $5,08 \%$ & $2,93 \%$ & $2,09 \%$ & $0,86 \%$ \\
\hline GRANJA 4 & $37,07 \%$ & $11,96 \%$ & $26,48 \%$ & $6,73 \%$ & $6,46 \%$ & $5,61 \%$ & $3,23 \%$ & $1,52 \%$ & $0,95 \%$ \\
\hline GRANJA 6 & $22,63 \%$ & $16,01 \%$ & $11,13 \%$ & $34,89 \%$ & $8,39 \%$ & $1,41 \%$ & $3,26 \%$ & $2,03 \%$ & $0,24 \%$ \\
\hline GRANJA 7 & $31,89 \%$ & $13,25 \%$ & $12,55 \%$ & $28,70 \%$ & $7,29 \%$ & $1,99 \%$ & $2,30 \%$ & $1,68 \%$ & $0,34 \%$ \\
\hline GRANJA 8 & $27,24 \%$ & $11,54 \%$ & $12,06 \%$ & $36,77 \%$ & $6,47 \%$ & $2,55 \%$ & $1,47 \%$ & $1,47 \%$ & $0,43 \%$ \\
\hline GRANJA 9 & $40,10 \%$ & $13,62 \%$ & $18,94 \%$ & $12,99 \%$ & $6,50 \%$ & $3,01 \%$ & $2,60 \%$ & $1,73 \%$ & $0,51 \%$ \\
\hline
\end{tabular}

Fonte: Dados da pesquisa. 
Tabela 10 - Comparativo entre os custos dos cenários e as exigências preconizadas pelas INs $n^{\circ} 56, n^{\circ} 59, n^{\circ} 36$ e $n^{\circ} 10$

\begin{tabular}{lcccc}
\hline & Cenário I & Cenário II & Cenário III & Cenário IV \\
\hline Custo Médio Produção / Caixa & $\mathbf{R} \mathbf{5 7 , 1 5}$ & $\mathbf{R} \mathbf{5 8 , 2 5}$ & $\mathbf{R} \mathbf{5 8 , 0 9}$ & $\mathbf{R} \mathbf{5 8 , 3 7}$ \\
Sanidade e Biosseguridade & $\mathbf{0} \%$ & $\mathbf{1 , 8 9 \%}$ & $\mathbf{1 , 6 1 \%}$ & $\mathbf{2 , 0 9 \%}$ \\
\hline Cerca de isolamento & - & $16,45 \%$ & $16,58 \%$ & $14,26 \%$ \\
Tela & - & $17,79 \%$ & - & $15,17 \%$ \\
Arco de desinfecção & - & $4,05 \%$ & $4,05 \%$ & $3,42 \%$ \\
Composteira & - & $2,92 \%$ & $2,93 \%$ & $2,48 \%$ \\
Responsabilidade Técnica (RT) & - & $46,87 \%$ & $47,39 \%$ & $40,05 \%$ \\
Análise de água & - & $0,68 \%$ & $0,69 \%$ & $0,58 \%$ \\
Controle de pragas e roedores & - & $2,26 \%$ & $2,29 \%$ & $1,93 \%$ \\
Limpeza e desinfecção & - & $8,87 \%$ & $8,96 \%$ & $7,57 \%$ \\
Exame de salmonela & - & - & $17,13 \%$ & $14,54 \%$ \\
\hline
\end{tabular}

Fonte: Dados da pesquisa. 


\section{CONCLUSÕES}

Acreditava-se que a adequação às Instruções Normativas teria um impacto socioeconômico significativo para a produção de ovos comerciais, pois, além das adequações da estrutura física e documental, deveria incentivar também uma mudança de comportamento do produtor diante das novas exigências. Os produtores deverão adaptar-se a uma nova conduta na gestão da produção. Terão, ainda, de lidar com custos adicionais e aplicação de recursos financeiros. Todos estes fatores, de fato, impactam no custo de produção. No entanto, o estudo sugere que as adequações à biosseguridade preconizadas pelas Instruções Normativas e, simuladas para os diferentes cenários, têm custo relativamente baixo frente aos possíveis riscos de enfermidades e dos prejuízos econômicos que essas enfermidades podem causar. Deste modo, as adequações são factíveis economicamente de serem realizadas, não justificando o abandono da atividade.

Deve-se, ainda, considerar que não é apenas a questão do custo em si que pode ser o problema da devida implementação das medidas preconizadas pelas Instruções Normativas, pois, podem existir outros fatores complicadores, como, o acesso à informação, a falta de cultura de gestão, falta de políticas de crédito agrícola e, as sucessivas alterações nas legislações, que podem fazer com que o programa de sanidade avícola perca a credibilidade diante da sociedade e dos produtores, que demonstram resistência às mudanças nos paradigmas zoosanitários.

Os trabalhos que envolvem análises de custo de produção de ovos são escassos na literatura, assim como trabalhos que avaliam os impactos socioeconômicos nesta atividade. Sendo assim, devido à importância da atividade avícola para o Estado de São Paulo e para o País, estudos que avaliem os impactos são necessários para introdução de novas políticas públicas. 


\section{REFERÊNCIAS}

ALVES, S. P.; SILVA, I. J. O.; PIEDADE, S. M. S. Avaliação do bem-estar de aves poedeiras comerciais: efeitos do sistema de criação e do ambiente bioclimático sobre o desempenho das aves e a qualidade de ovos. Revista Brasileira de Zootecnia, v. 36, n. 5, p. 1388-1394, 2007.

ANEEL. AGENCIA NACIONAL DE ENERGIA ELÉTRICA. Tarifas de fornecimento de enegia elétrica. / Brasília: ANEEL, 2005. 30 p. (Cadernos Temáticos, 4).

AULER, J. R.; TEIXEIRA, A. J. C.; TEIXEIRA, A. M. C.; BAPTISTA, E. C. S. Impacto da evolução futura dos preços dos ovos no desempenho de uma granja de aves de postura comercial. Revista Universo Contábil, Blumenau, v. 5, n. 2, p. 58-70, abr./jun. 2009.

AVICULTURA INDUSTRIAL. Mapa lança projeto pioneiro na avicultura industrial. Publicação Eletrônica. Quinta-feira, 10 de Novembro de 2011. Disponível em: http://www.aviculturaindustrial.com.br/noticia/mapa-lanca-projeto-pioneiro-emavicultura - industrial/20111110094921 Y 646. Acesso em: 18 abr. 2011.

AVICULTURA INDUSTRIAL. Associação catarinense de avicultura (Acav) apoia novas normas de biosseguridade para avicultura. Publicação Eletrônica. Sextafeira, 24 de Fevereiro de 2012. Disponível em:

http://www.aviculturaindustrial.com.br/noticia/acav-apoia-novas-normas-debiosseguridade-para-avicultura/20120224153403 K 910. Acesso em: 01 set. 2012.

BABBIE, E. Métodos de pesquisas de Survey. Belo Horizonte: Editora UFMG, 1999. $519 \mathrm{p}$.

BELUSSO, D. O perfil socioeconômico dos avicultores do município de Palotina, no Oeste do Paraná. In: VIII ENCONTRO DE ECONOMIA PARANAENSE, 8., 2010, Maringá. Anais... 2010.

BELUSSO, D. HESPANHOL, A. N.; A evolução da avicultura industrial brasileira e seus efeitos territoriais. Revista Percurso - NEMO, Maringá, v. 2, n. 1, p. 25-51, 2010.

BOARETTO, T. N. Melhoramento genético em frangos de corte. Revista Formação Informação Zootecnia, v. 1, n. 1, p. 11-18, 2009. 
BOCKMA, B. Report of the committee on transmissible diseases of poultry and other avian species. In: UNITED STATES ANIMAL HEALTH ASSOCIATION (USAHA), 1998, [S.I]. Proceedings ... 1998. p. 638-9.

BRANDALIZE, V. H. BR X EUA: o que funciona melhor nas granjas brasileiras? Publicação Eletrônica: Avesite, 2013. Disponível em:

<http://www.avisite.com.br/noticias/index.php?codnoticia=14615>. Acesso em: 02 nov. 2013.

BRASIL. Gabinete da Presidência da República. Decreto № 24.548 de 3 de Julho de 1934. Aprova o Regulamento do Serviço de Defesa Sanitária Animal. Coleção de Leis do Brasil, 1934.

BRASIL. Gabinete da Presidência da República. Lei oㅜ 569 de 21 de dezembro de 1948. Estabelece medidas de defesa sanitária animal. Diário Oficial [da] União, Brasília, DF, 23 dez.1948.

BRASIL. Gabinete da Presidência da República. Decreto n 30.691, de 29 de março de 1952. Aprova o novo Regulamento da Inspeção Industrial e Sanitária de Produtos de Origem Animal. Diário Oficial [da] União, Brasília, DF, 07 jul. 1952.

BRASIL. Ministério da Agricultura Pecuária e Abastecimento - MAPA. Portaria Ministerial no 193 de setembro de 1994. Institui o Programa Nacional de Sanidade Avícola no âmbito da SDA e cria o Comitê Consultivo do Programa de Sanidade Avícola. Diário Oficial [da] União, Brasília, DF, 22 set. 1994. Seção 1, p. 14309.

BRASIL. Ministério da Agricultura, Pecuária e Abastecimento - MAPA. Secretaria de Defesa Agropecuária. Instrução Normativa DSA no 44 de 23 de agosto de 2001. Aprova as normas técnicas para o controle e a certificação de núcleos e estabelecimentos avícolas para a micoplasmose aviária. Diário Oficial [da] União, Brasília, DF, 24 ago. 2001. Seção 1, p. 68.

BRASIL. Ministério da Agricultura Pecuária e Abastecimento - MAPA. Secretaria de Defesa Agropecuária. Departamento de Defesa Animal. PNSA. Manual Técnico de Procedimentos Operacionais de Atividades de Campo. Brasília, 2002a. 85 p.

BRASIL. Ministério da Agricultura Pecuária e Abastecimento - MAPA. Secretaria de Defesa Agropecuária. Instrução Normativa SDA № 32, de 13 de maio de 2002. Aprovar as Normas Técnicas de Vigilância para doença de Newcastle e Influenza Aviária, e de controle e erradicação para a doença de Newcastle. Diário Oficial [da] União, Brasília, DF, 14 maio 2002b. Seção 1, p. 28. 
BRASIL. Ministério da Agricultura Pecuária e Abastecimento - MAPA. IN no 11 de 01 de setembro de 2003. Declara os plantéis avícolas industriais dos Estados do Rio Grande do Sul, Santa Catarina, Paraná, São Paulo, Minas Gerais, Goiás, Mato Grosso do Sul, Mato Grosso e do Distrito Federal livres da doença de Newcastle. Diário Oficial [da] União, Brasília, DF, 05 set. 2003a. Seção 1, p. 3.

BRASIL. Ministério da Agricultura, Pecuária e Abastecimento - MAPA. Secretaria de Defesa Agropecuária. Instrução Normativa no 78 de 3 de novembro de 2003. Aprova as normas técnicas para o controle e certificação de núcleos e estabelecimentos avícolas, como livres de Salmonella Gallinarum e de Salmonella Pullorum e livres ou controlados para Salmonella Enteritides e para Salmonella Typhimurium. Diário Oficial [da] União, Brasília, DF, 05 nov. 2003b. Seção 1, p. 3.

BRASIL. Ministério da Agricultura Pecuária e Abastecimento - MAPA. IN no 17 de 07 de Abril de 2006. Aprovar, no âmbito do Programa Nacional de Sanidade Avícola, o Plano Nacional de Prevenção da Influenza Aviária e de Controle e Prevenção da Doença de Newcastle. Diário Oficial [da] União, Brasília, DF, 10 abr. $2006 a$. Seção 1, p. 6.

BRASIL. Gabinete da Presidência da República. Decreto nำ5.741, de 30 de março de 2006. Organiza o Sistema Unificado de Atenção à Sanidade Agropecuária, e dá outras providências. Diário Oficial [da] União, Brasília, DF, 10 abr. 2006b.

Seção 1, p. 82.

BRASIL. Ministério da Agricultura Pecuária e Abastecimento - MAPA. Secretaria de Defesa Agropecuária. Departamento de Saúde Animal. Procedimentos permanentes de vigilância para influenza aviária e doença de Newcastle. Oficio circular DAS, Brasília, $n^{\circ} 7$, p. 1-9, 2007a.

BRASIL. Ministério da Agricultura Pecuária e Abastecimento. Instrução Normativa MAPA n 56 DE 04 de dezembro de 2007. Estabelece os Procedimentos para Registro, Fiscalização e Controle de Estabelecimentos Avícolas de Reproduçao e Comerciais. Diário Oficial [da] União, Brasília, DF, 06 dez. 2007b. Seção 1, p. 11.

BRASIL. Ministério da Agricultura, Pecuária e Abastecimento - MAPA. Secretaria de Defesa Agropecuária. Departamento de Saúde Animal. Manual de Legislação: Programa Nacional de Saúde Animal do Brasil. Brasília: MAPA/SDA/DSA, 2009a. $440 \mathrm{p}$.

BRASIL. Ministério da Agricultura Pecuária e Abastecimento - MAPA. Plano de contingência para Influenza Aviária e Doença de Newcastle. Brasília, 2009b. Versão 1.3. 
BRASIL. Ministério da Agricultura Pecuária e Abastecimento - MAPA. Instrução Normativa no 59 de 02 de dezembro de 2009. Altera a Instrução Normativa MAPA no 56, de 4 de dezembro de 2009. Diário Oficial [da] União, Brasília, DF, 04 dez. 2009c. Seção 1, p. 4.

BRASIL. Ministério da Agricultura Pecuária e Abastecimento - MAPA. INSTRUÇÃO NORMATIVA № 36, DE 6 DE DEZEMBRO DE 2012. Altera, renumera, acrescenta e revoga, anexos, artigos, parágrafos e incisos da Instrução Normativa ${ }^{\circ} 56$. Diário Oficial [da] União, Brasília, DF, 07 dez. 2012. Seção 1, p. 25.

BRASIL. Ministério da Agricultura Pecuária e Abastecimento. MAPA. Aves. Disponível em: http://www.agricultura.gov.br/animal/especies/aves . Acesso em: 17 de abril de 2013a.

BRASIL. Ministério da Agricultura Pecuária e Abastecimento - MAPA. INSTRUÇÃO NORMATIVA № 10, DE 11 DE ABRIL DE 2013. Define o programa de gestão de risco diferenciado para os estabelecimentos avícolas considerados de maior susceptibilidade à introdução e disseminação de agentes patogênicos no plantel avícola nacional e para estabelecimentos avícolas que exerçam atividades que necessitam de maior rigor sanitário. Diário Oficial [da] União, Brasília, DF, 12 abr. 2013b. Seção 1, p. 2.

BRASIL. Ministério da Agricultura Pecuária e Abastecimento - MAPA. INSTRUÇÃO NORMATIVA № 50, DE 24 DE SETEMBRO DE 2013. Alterar a lista de doenças passíveis da aplicação de medidas de defesa sanitária animal, previstas no art. 61 do Regulamento do Serviço de Defesa Sanitária Animal, publicado pelo Decreto $\mathrm{n}$ 24.548, de 3 de julho de 1934. Diário Oficial [da] União, Brasília, DF, 25 set. 2013c. Seção 1, p. 47.

BUCHALA, F. G. Planejamento, Implantação e Administração de medidas de Defesa Sanitária Animal para o controle da Laringotraqueíte Infecciosa Aviária de 2002 a 2006, na região de Bastos, Estado de São Paulo, Brasil. 2008. 173 p. Tese (Doutorado) Faculdade de Ciências Agrárias e Veterinárias - UNESP, Campus de Jaboticabal, Jaboticabal, 2008.

BUIM, M. R.; GUASTALLI E. A. L; ONO, M. A.; OLIVEIRA, R. A. Avaliação da eficiência da desinfecção ambiental em aviários de postura comercial. In: CONGRESSO APA - PRODUÇÃO E COMERCIALIZAÇÃO OVOS, 11., 2013, Ribeirão Preto. Anais... 2013. 
CAIDEN, G.; CARAVANTES, G. Reconsiderações do conceito de desenvolvimento. Caxias do Sul: Educs, 1988. 610 p.

CALLADO, A. A. C. Agronegócio. São Paulo: Atlas, 2005.142 p

CASTRO, A. G. M. Importância do intercâmbio técnico entre o setor público e privado em prol do desenvolvimento da avicultura. In: SIMPÓSIO BRASIL SUL DE AVICULTURA E II BRASIL SUL POULTRY FAIR, 11., 2010, Chapecó. Anais... 2010.

DOMINGUES, P. F. Sanidade animal no Brasil e o desenvolvimento da Agropecuária. Revista Internacional em Língua Portuguesa, n. 21, p. 93-105, 2008.

DONATO D. C. Z.; GANDRA, E. R. S.; GARCIA, P. D. S. R; REIS, C. B. M.; GAMEIRO, A. H. A questão da qualidade no sistema agroindustrial do ovo. In: CONGRESSO SOBER, 47., 2009, Porto Alegre. Anais... 2009.

EMBRAPA. Empresa Brasileira de Pesquisa Agropecuária. Manual de segurança e qualidade para a avicultura de postura. Brasília: Embrapa Informação Tecnológica. 2004, 97 p.

FAO. FOOD AND AGRICULTURE ORGANIZATION. Anuário Estatístico 2012. Disponível em: <https://www.fao.org.br>. Acesso em: 15 abr. 2012.

FASSARELA, R. A.; COVRE, J. Cadeia Produtiva da Avicultura de Postura: Um estudo no município de Santa Maria de Jequitibá no Estado do Espirito Santo. In: CONGRESSO DA SOCIEDADE BRASILEIRA DE ECONOMIA, ADMINISTRAÇÃO E SOCIOLOGIA RURAL, 48., 2010, Campo Grande. Anais... 2010.

FRANCO, A. Ação Local: a nova política da contemporaneidade. Brasília: Instituto de Política, 1995.

FRANCO, A. Além da renda. Brasília: Instituto de Política, 2000.

FREITAS, L. B. A evolução da avicultura de corte brasileira após 1980. Economia e desenvolvimento, n. 13, p. 38, 2001. 
FREITAS, H.; OLIVEIRA, M.; SACCOL, A. Z.; MOSCAROLA, J. O método de pesquisa Survey. São Paulo/SP. Revista de Administração da USP, v. 35, n. 3, p. 105-112, 2000.

GALLO, B. B. Situação atual da avicultura do México em relação a enfermidades exóticas e análise comparativa da situação de risco com o Brasil. In: CONGRESSO BRASILEIRO DE AVICULTURA, 23., 2013, São Paulo. Anais... 2013.

GAVINELLI, A. O progresso na implementação das regulamentações de bem-estar animal para aves. In: CONGRESSO BRASILEIRO DE AVICULTURA, 23., 2013, São Paulo. Anais... 2013.

GEWEHR, C. E.; STAHLHOFER, S. R.; RITTER, G. S.; SILVA, M. C. Cadeia produtiva de ovos comerciais de Santa Catarina: perfil dos produtores e das propriedades. Revista de Ciências Agroveterinárias. Lages, v. 9, n. 1, p. 90-98, 2010.

GIROTTO, A. F.; MIELE, M. Análise da situação atual e perspectivas da avicultura de corte. Revista Ave World, Paulínia, v. 14, p. 16-20, 2005.

GOLDBERG, R. A. Agribusiness coordination: a systems approach to the wheat, soybean, and florida orange economies. Division Research. Graduate School of Business and Administration. Cambridge: Harvard University, 1968. 256 p.

HELLMEISTER FILHO, P. Efeitos de fatores genéticos e do sistema de criação sobre o desempenho e o rendimento de carcaças de frango tipo caipira. 2003. 77 p. Tese (Doutorado) - Escola Superior de Agricultura Luiz de Queiroz, Piracicaba, 2003.

HESTER, P. Y. Impact of science and management on the welfare of egg laying strains of hens. Poultry Science, Champaign, v. 84, p. 687-696, 2005.

HOERR, F. J.; LOCKABY, S. B.; BICKFORD A. A. Poultry Mycoplasma WorkshopHistopathology. California: [s.n], 1994. p.1-12.

HOFFMANN, R.; ENGLER, J. J. C.; SERRANO, O.; THAME, A. C. M.; NEVES, E. M. Administração da empresa agrícola. 7. ed. São Paulo: Pioneira, 1992. 325 p.

IBGE. INSTITUTO BRASILEIRO DE GEOGRAFIA E ESTATÍSTICA. SIDRA. 2012. Disponível em: <www.sidra.ibge.gov.br>. Acesso em: 15 abr. 2012. 
IBGE. INSTITUTO BRASILEIRO DE GEOGRAFIA E ESTATÍSTICA. SIDRA. 2013. Disponível em: <www.sidra.ibge.gov.br>. Acesso em: out. 2013.

INTEGRA BRASIL. Agência de Integração à Saúde. Meio Ambiente e Desenvolvimento Social do Brasil. Fórum nacional de agronegócios: boas práticas de produção e estimulo a indústria nacional: pós rio + 20. Brasília [s.n], 2012.

KAKIMOTO, S. K.; SOUZA FILHO, H. M.; PIZZOLANTE C. C.; MORAES, J. E. Fatores críticos da competitividade da cadeia produtiva do ovo no Estado de São Paulo. In: CONGRESSO BRASILEIRO DE AVICULTURA, 23., 2013, São Paulo. Anais... 2013.

KING, D. J. Enfermedad de Newcasite. In: CONGRESSO LATINOAMERICANO DE AVICULTURA, 16., 1999, Lima. Anais... 1999. p. 56-62.

KLEVEN, S. H.; ROWLAND, G. N.; OLSON, N. O. Mycoplasma synoviae infection. In: CALNEK, B. W.; BARNES, H. J.; BEARD, C. W.; REID, W. M.; YODER JUNIOR, H. W. (Ed.). Diseases of poultry. 9. ed. Ames: lowa State University Press, 1991. p. 223-231.

LAGATTA, L.; POLYCARPO, G. V.; GAMBARO, D. V.; GAMEIRO, A. H.; STIVARI, T S. S.; CAPODIFOGLIO, E. Análise da transação entre incubatório e granjas de postura comercial da regional agrícola de Limeira sob a ótica da economia dos custos de transação. In: CONGRESSO APA - PRODUÇÃO E COMERCIALIZAÇÃO OVOS, 11., 2013, Ribeirão Preto. Anais... 2013.

LAGANÁ, C.; PIZZOLANTE, C. C.; MORAES, J. E. Alternativas de métodos de muda forçada para melhora do bem estar de poedeiras neste período. In: CONGRESSO APA - PRODUÇÃO E COMERCIALIZAÇÃO OVOS, 11., 2013, Ribeirão Preto. Anais... 2013.

LAMPERT, J. A. Administração rural. Santa Maria: DEAER/UFSM, 2003. 121 p. (Administração Rural).

LANA, G. R. Q. Avicultura. Campinas: Livraria e Editora Rural Ltda, 2000. 253 p.

LOPES, M. A.; CARVALHO, F. C. Custo de produção do gado de corte. Lavras: UFLA, 2002. $47 \mathrm{p}$. 
LOURENÇONI, D.; YANAGI, T.; JUNIOR; OLIVEIRA, D. D.; LIMA, R. R.; OLIVEIRA, B. L.; CAMPOS, A. T.; PENA, M. R. S. Avaliação do uso de tela em galpões para galinhas poedeiras e sua influência na temperatura interna e índices zootécnicos. In: CONGRESSO BRASILEIRO DE AVICULTURA, 23., 2013, São Paulo. Anais... 2013.

MÁRQUEZ, M. A. Um foco de Influenza Aviária tipo A/H7N3 de Alta Patogenicidade e exótica em Jalisco, 2012, e Guanajuato-Puebla, 2013 - México. In: CONGRESSO BRASILEIRO DE AVICULTURA, 23., 2013, São Paulo. Anais... 2013.

MARTIN, N. B.; SERRA, R.; ANTUNES, J. F. G.; OLIVEIRA, M. D. M.; OKAWA, H. Custos: sistema de custo de produção agrícola. Informações Econômicas, v. 24, n. 9, p. $97-122,1994$.

MARTINS, S. S. Cadeias produtivas do frango e do ovo: avanços tecnológicos e sua apropriação. 1996. 112 p. Tese (Doutorado em Economia) - Fundação Getúlio Vargas, São Paulo, 1996.

MARTINS, S. S.; LEMOS, A. L.; DEODATO, A. P.; POLITI, E. S.; QUEIROZ, N. M. S. Cadeia produtiva do ovo no Estado de São Paulo. Informações Econômicas, São Paulo, v. 30, n. 1, p. 7-29, 2000.

MATSUNAGA, M.; BEMELMANS, P. F.; TOLEDO, P. E. N. de; DULLEY, R. D.; OKAWA, H.; PEDROSO, I. A. Metodologia de custo de produção utilizada pelo IEA. Agricultura em São Paulo, São Paulo, v. 23, n. 1, p. 123-39, 1976.

MAZZUCO, H.; KUNZ, A.; PAIVA, D. P.; JAENISCH, F. R. F.; PALHARES, J. C. P.; ABREU, P. G.; ROSA, P. S.; AVILA, V. S. Boas Práticas de Produção na Postura Comercial. Circular Técnica, EMBRAPA Suínos e Aves, № 49, p. 1-40, 2006.

McLEOD, A.; MORGAN, N.; PRAKASH, A.; HINRICHS, J. Economic and Social Impacts of Avian Influenza. FAO Emergency Centre for Transboundary Animal Diseases Operations, 2005. Disponível em: $<$ http://www.fao.org/docs/eims/upload//211939/Economic-and-social-impacts-ofavian-influenza-Geneva.pdf>. Acesso em: 01 set. 2012.

MICHEL, M. H. Metodologia e pesquisa científica em ciências sociais. 2. ed. São Paulo: Atlas, 2009.

MICROSOFT. Microsoft Office Excel®. Microsoft Corporation. California, 2007. 
MIZUMOTO, C. A. Comunicação Empresarial na Avicultura de Postura: Brasil e Argentina (uma Análise Comparada). 1996. 154 p. Dissertação (Mestrado em Comunicação). Universidade de São Paulo, São Paulo, 1996.

MIZUMOTO, F. M. Estratégias nos canais de distribuição de ovos: análise dos arranjos institucionais simultâneos. 2004. 95 p. Dissertação (Mestrado em Administração) - Universidade de São Paulo, São Paulo, 2004.

MIZUMOTO, F. M.; ZYLBERSZTAJN, D. Relações contratuais no sistema agroindustrial de ovos. São Paulo: FEA; USP, 2008. 14 p. (Série Working paper 03/023).

MOHAMMED, H. O.; CARPENTER, T. E.; YAMAMOTO, R. Economic impact of Mycoplasma gallisepticum and Mycoplasma synoviae in commercial layer flocks. Avian Disease, v. 31, p. 477-482, 1987.

NELSON, D. Tendências no comércio Internacional. In: CONGRESSO BRASILEIRO DE AVICULTURA, 23., 2013, São Paulo. Anais... 2013.

NETO, E. R. M.; POLESEL. D. N.; SOUSA, E.; SARKIS, C. A. Pesquisa de opinião pública sobre a tendência de mercado dos ovos e suas características desejáveis ao consumidor final. In: CONGRESSO APA - PRODUÇÃO E COMERCIALIZAÇÃO OVOS, 11., 2013, Ribeirão Preto. Anais... 2013a.

NETO, E. R. M.; POLESEL. D. N.; SOUSA, E.; SARKIS, C. A. Análise do consumidor final de ovos com relação à qualidade sanitária dos produtos. In: CONGRESSO APA - PRODUÇÃO E COMERCIALIZAÇÃO OVOS, 11., 2013, Ribeirão Preto. Anais... 2013b.

OIE. ORGANIZAÇÃO MUNDIAL DE SAÚDE ANIMAL. Código Sanitário dos Animais Terrestres, v.1, Seção 4, cap. 4.3 e 4.4. OIE, 2004.

PARAGUASSU, A. Atualidades da produção mundial de ovos. In: CONGRESSO BRASILEIRO DE AVICULTURA, 23., 2013, São Paulo. Anais... 2013.

PASIAN, I. M.; GAMEIRO, A. H. Mercado para criação de poedeiras em sistemas do tipo orgânico, caipira e convencional. In: CONGRESSO DA SOCIEDADE BRASILEIRA DE ECONOMIA, ADMINISTRAÇÃO E SOCIOLOGIA RURAL, 45., 2007, Londrina. Anais... Londrina: Universidade Estadual de Londrina, 2007. 
PAULILLO, A. C. Estudo experimental da resposta imunitária às vacinas inativada (oleosa) e viva (amostra LaSota) contra a doença de Newcastle. 1984. 129 p. Tese Doutorado - Instituto de Ciências Biomédicas, Universidade de São Paulo, São Paulo, 1984.

QUEVEDO, A. Experiência com a gripe. Revista Avicultura Industrial, v. 1141, p. 38-39, 2006.

RAINERI, C. Desenvolvimento de modelo de cálculo e de indicador de custos de produção para a ovinocultura paulista. 2012. $230 \mathrm{f}$. Tese (Doutorado) Universidade de São Paulo, Faculdade de Medicina Veterinária e Zootecnia, Departamento de Nutrição e Produção Animal, Pirassununga, 2012.

RAMI, S. Agregação de valor na produção de ovos. In: CONGRESSO BRASILEIRO DE AVICULTURA, 23., 2013, São Paulo. Anais... 2013.

RATTNER, H. Liderança para uma sociedade sustentável. São Paulo: Nobel, 1999.

REVOLLEDO, L.; FERREIRA, A. J. P. (Org.). Patologia aviária. Barueri: Editora Manole, 2009. $510 \mathrm{p}$.

RIZZI, A. T. A indústria de frangos no Brasil: constituição e transformações. Economia Urbano Industrial, v. 1, p. 1-1, 1999. Trabalho apresentado no III Congresso Brasileiro de História Econômica, 1999, Curitiba.

ROCHA JR, W. F. Análise do agronegócio da erva mate como enfoque na nova economia institucional e o uso da matriz estrutural prospectiva. 2001. [110 p.]. Tese (Doutorado) - Universidade Federal de Santa Catarina. Tese de Doutorado em Engenharia da Produção, Florianópolis, 2001.

RURAL PECUÁRIA. Mapa estabelece norma que define programa de gestão de risco diferenciado para estabelecimentos avícolas. 2013. Disponível em: $<$ http://www.ruralpecuaria.com.br/2013/04/mapa-estabelece-norma-quedefine.html>. Acesso em: 17 abr. 2013.

SÃO PAULO (Estado). Decreto Estadual n 43.424, de 1ํ de setembro de 1998. Altera a subordinação e o nível do Departamento de Defesa Agropecuária da Coordenadoria de Assistência Técnica Integral (CATI) na Secretaria de Agricultura e Abastecimento. Diário Oficial do Estado, 02 ago. 1998a. p. 5. 
SÃO PAULO (Estado). Decreto Estadual n 43.512, de 2 de outubro de 1998. Dispõe sobre a organização da Coordenadoria de Defesa Agropecuária da Secretaria de Agricultura e Abastecimento e dá providências correlatas. Diário Oficial do Estado, 02 out. 1998b. p. 1-4.

SÃO PAULO (Estado). Lei Estadual n ${ }^{\circ} 10.670$ DE 24 de outubro de 2000. Dispõe sobre a adoção de medidas de defesa sanitária animal no âmbito do Estado. Diário Oficial do Estado, 25 out. 2000. p. 2-3.

SÃO PAULO (Estado). Decreto oㅜ 45.782 de 27 de abril de 2001. Define os Programas de Sanidade Animal, de Peculiar Interesse do Estado, em conformidade com o Decreto № 45.782, de 27 de abril de 2001, que regulamenta a Lei no 10.670 , de 24 de outubro de 2000, que dispõe sobre a adoção de medidas de defesa sanitária animal no âmbito do Estado e dá outras providências corretas. Diário Oficial do Estado, 24 abr. 2001a. p. 6.

SÃO PAULO (Estado). Decreto Estadual n 45.781 de 27 de abril de 2001. Regulamenta a Lei no 10.670 , de 24 de outubro de 2000, que dispõe sobre a adoção de medidas de defesa sanitária animal no âmbito do Estado e dá outras providências correlatas. Diário Oficial do Estado, 28 abr. 2001b. p. 2-6.

SÃO PAULO (Estado). Resolução SAA n 54 de 12 de dezembro de 2006. Considera a Influenza Aviária doença de peculiar interesse do Estado, aprova 0 Projeto de Controle e Erradicação das Salmoneloses, das Micoplasmoses e da Doença de Newcastle e de Prevenção e Combate da Influenza Aviária e estabelece as exigências a serem cumpridas pelos estabelecimentos avícolas 0de controles permanente e eventual, visando a biosseguridade do sistema de produção avícola e dá outras providências. Diário Oficial do Estado, 15 dez. 2006. p. 20.

SÃO PAULO (Estado). Coordenadoria de Defesa Agropecuária - CDA. Plano estadual de contingência para influenza aviária e doença de newcastle. São Paulo: CDA, 2010a.

SÃO PAULO (Estado). Coordenadoria de Defesa Agropecuária - CDA. Portaria CDA №. 8, de 17 de março de 2010. Dispõe sobre os procedimentos para registro e fiscalização de estabelecimentos avícolas comerciais localizados no Estado de São Paulo. Diário Oficial do Estado, 19 mar. 2010b. p. 20.

SÃO PAULO (Estado). Coordenadoria de Defesa Agropecuária - CDA. Resolução SAA №. 58 de 14 de dezembro de 2010. Estabelece as medidas de profilaxia inespecíficas e específicas para o controle da Laringotraqueíte Infecciosa das Aves, a serem cumpridas pelos estabelecimentos avícolas de produção de ovos 
comerciais, localizados no município de Guatapará e dá outras providências. Diário Oficial do Estado, 15 dez. 2010c. p. 20.

SÃO PAULO (Estado). Secretaria de Agricultura e Abastecimento - SAA. Resolução $n^{\circ} 81$ de 13 de dezembro de 2012 Redefine as sedes e respectivas áreas territoriais de atuação das Inspetorias de Defesa Agropecuária, dos Escritórios de Defesa Agropecuária, da Coordenadoria de Defesa Agropecuária, da Secretaria de Agricultura e Abastecimento. Diário Oficial do Estado, 14 dez. 2012. p. 26.

SEAGRI. SECRETARIA DE AGRICULTURA E DESENVOLVIMENTO RURAL DO DISTRITO FEDERAL. MAPA - Dois anos para mudar. 2010. Disponível em: $<$ http://www.seapa.df.gov.br/003/00301009.asp?ttCD CHAVE=94714>. Acesso em: 16 fev. 2012.

SEN, A. Desenvolvimento como liberdade. São Paulo: Companhia das Letras, 2000.

SESTI, L. A. C. Biosseguridade em granjas de produtores avícolas. In: MACARI, M.; MENDES, A. A. Manejo de matrizes de corte. Jaboticabal: FACTA, 2005, p.243322.

SESTI, L. A. C. Filosofias e conceitos de Biosseguridade e doenças com potencial de risco para a avicultura brasileira. In: CONFERÊNCIA APINCO 2001 DE CIÊNCIA E TECNOLOGIA AVÍCOLAS, 2001, Campinas, Anais... Campinas: FACTA, 2001. v. 1, p.47-91.

SHERWELL, P.; SAWYER, W. Recovering from a bad case of the flu. Rabobank Industry Note, n. 414, 2013. 7 p.

SILVA, R. W. S. M. da; OLIVEIRA, J. C. P.; EGGLETON , C. M. J.; ECHEVARRIA, F.; PINHEIRO, A. C. Sistema de criação de bovinos de leite para a região sudoeste do Rio Grande do Sul. Bagé: Embrapa Pecuária Sul, 2008. 77 p.

SINDUSCON-SP. Sindicato da Indústria da Construção Civil do Estado de São Paulo. Custo Unitário Básico (CUB/m²). Boletim Econômico, São Paulo, 2013. Disponível em: http://www.sindusconsp.com.br/secoes.asp?subcateg=44\&categ=8, Acesso em: 15 jul. 2013.

SLUZZ, T.; PADILHA, A. C. M.; MATTOS, P.; SILVA, T. N. O impacto da instrução normativa 51 no sistema agro industrial do leite no Rio Grande do Sul: uma análise na Elegê Alimento s S/A e na Cooperativa Languiri LTDA. In: CONGRESSO 
BRASILEIRO DE ECONOMIA E SOCIOLOGIA RURAL, 44., 2006, Fortaleza. Anais... 2006.

SOBRINHO, J. K.; FONSECA, R. A. Análise econômica da produção de ovos de galinhas poedeiras no Município de Toledo - PR. Revista Eletrônica Lato Sensu, v. 2, n. 1, julho de 2007. Disponível em: < http://pt.scribd.com/doc/139497806/Analise-economica-da-producao-de-ovos-degalinhas-poedeiras-pdf>. Acesso em: 16 fev. 2012.

STEFANELLO, C. Análise do sistema agroindustrial de ovos comerciais. Nota Técnica. Revista Agraria, Dourados, v. 4, n. 14, p. 375-382, 2011.

UBABEF. UNIÃO BRASILEIRA DE AVICULTURA E ASSOCIAÇÃO BRASILEIRA DOS EXPORTADORES DE FRANGO. Relatório Anual. 2013. disponível em: < http://www.ubabef.com.br/files/publicacoes/732e67e684103de4a2117dda9ddd280a. pdf > Acesso em: 20 out. 2013.

UNIÃO EUROPÉIA. Diretiva nº 74 de 19 de julho de 1999. Estabelece as normas mínimas relativas a proteção das galinhas poedeiras. Jornal Oficial da Comunidade Européia, v. 203, p. 53, 1999.

VALENTE, L. C. M.; GOMES, M. F. M.; CAMPOS, A. C. Impactos da Influenza Aviária no Mercado Internacional de Carnes. In: CONGRESSO BRASILEIRO DE ECONOMIA E SOCIOLOGIA RURAL, 47., 2009, Porto Alegre. Anais... 2006

VAN HORNE, P. L. M.; ACHTERBOSCH, T. J. Animal welfare in poultry production systems: impact of EU standards on world trade. Worlds Poultry Science Journal, v. 64 , p. $40-52,2008$.

VEIGA, L.; GONDIM, S. M. G. A utilização de métodos qualitativos na ciência política e no marketing político. Opinião Pública, v. 2, n. 1, p. 1-15, 2001.

VIANA, G. R. Eficiência de telas de arame na segregação de aves de vida livre para a biossegurança de aviários comerciais. 2010.62 p. Dissertação de Mestrado, Universidade Federal de Minas Gerais, Escola de Veterinária, Belo Hoizonte, 2010.

VIEIRA. N. M.; DIAS. R. S. Uma abordagem sistêmica da avicultura de corte na economia brasileira. Viçosa: Universidade Federal de Viçosa, 2004. 
VILELA JUNIOR, G. B. A pesquisa qualitativa. 2007. Disponível em: $<$ http://www.guanis.org/metodologia/a pesquisa qualitativa.pdf $>$. Acesso em: 01 ago. 2010.

YODER JR., H. W. Mycoplasma gallisepticum infections. In: CALNEK, B. W.; BARNES, H. J.; BEARD, C. W.; REID, W. M.; YODER, JR. H. W. (Ed.). Diseases of poultry. 11th ed. Ames: lowa State University Press, Ames, 1991. p. 198-212. 
ANEXO A - Folder de divulgação do I Encontro dos Produtores de Ovos da Regional Agropecuária de Limeira.

\section{ENCONTRO DOS PRODUTORES DE OVOS DA REGIONAL AGROPECUÁRIA DE LIMEIRA}

\section{"Políticas Sanitárias Avícolas e seu Impacto Socioeconômico "}
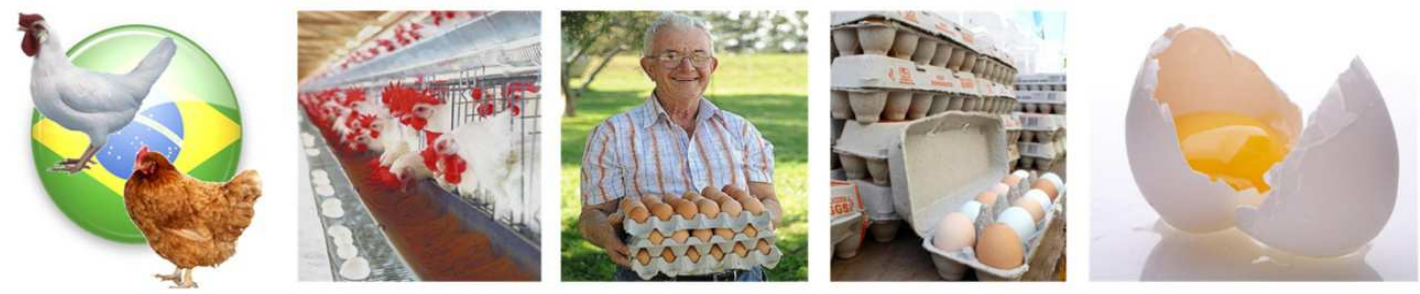

Data: 04 de Junho de 2013 (Terça-feira)

Horário: $13 \mathrm{~h} 30$ às $18 \mathrm{~h}$

Local: Anfiteatro Armando Chieffi - FMVZ, campus da USP de Pirassununga.

INSCRIÇÕES GRATUITAS : lae@usp.br ou (19) 3565-4224

\section{PROGRAMA DETALHADO}

13 h 30 Inscrições e entrega de material

$14 \mathrm{~h}$ Cerimônia de abertura

Enrico Lippi Ortolani - Diretor da Faculdade de Medicina Veterinária e Zootecnia (FMVZ/USP)

Heinz Otto Hellwig - Coordenador da Coordenadoria de Defesa Agropecuária do Estado de São Paulo (CDA/SAA)

Francisco Palma Rennó - Chefe do Departamento de Nutrição e Produção Animal (FMVZ/USP)

Antonio Carlos Junqueira do Val Filho - Diretor do EDA Limeira (CDA/SAA)

Augusto Hauber Gameiro - Coordenador do Laboratório de Análises Socioeconômicas e Ciência Animal (LAE/FMVZ/USP)

14 h 30 Palestra de abertura - Políticas Sanitárias para Produção Avícola - M.V. Luciano LaGatta Chefe de Seção Técnica da Inspetoria de Defesa Agropecuária de Pirassununga (CDA-SAA) Mestrando do Programa de Pós-graduação em Nutrição e Produção Animal (FMVZ/USP)

15 hegistro de Estabelecimento Avícola Comercial - M.V. Bruno Marinho Gerente do Programa Estadual de Sanidade Avicola (PESA/CDA/SAA)

15 h 30 Salmoneloses - Diagnóstico e Controle - M.V. MSc. Maria Fernanda de Castro Burbareli Doutoranda do Programa de Pós-graduação em Nutrição e Produção Animal (FMVZ/USP)

$16 \mathrm{~h}$ Intervalo para "coffee break"

16 h 30 Biosseguridade na Indústria Avícola - M.V. Thiago Ferraz Corrêa Suiaves Comércio de Produtos Veterinários LTDA

17 h Estudo Socioeconômico na Avicultura de Postura - M.V. Luciano LaGatta Chefe de Seção Técnica da Inspetoria de Defesa Agropecuária de Pirassununga (CDA-SAA) Mestrando do Programa de Pós-graduação em Nutrição e Produção Animal (FMVZ/USP)

17 h 30 Mesa Redonda

$18 \mathrm{~h}$ Encerramento do evento e entrega de certificados

Vagas Limitadas. E-mail: lae@usp.br Tel.: (19) 3565-4224

Organização

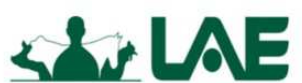

Patrocínio

$\overline{\bar{A}}$ SSOCIACÃO PAULISTA DE
Apoio

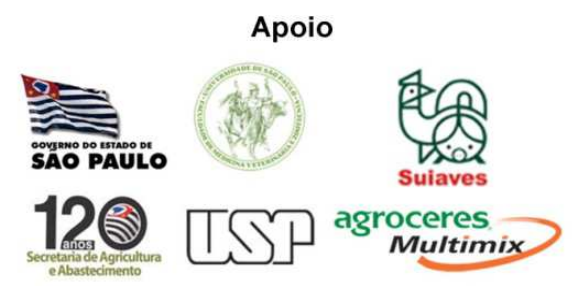




\section{ANEXO B - Questionário do Perfil socioeconômico da atividade avícola de postura.}

1. Área destinada a atividade avícola na propriedade?

2. Número de galpões:

3. Capacidade total de alojamento da granja?
a. ( ) Até 5.000 aves
b. ( ) 5.000 a 20.000 aves
C. ( ) 20.000 a 50.000 aves
d. ( ) 50.000 a 100.000 aves
e. ( ) Acima de 1000.000 aves

4. Propriedade/Granja:
a. ( ) Própria
b. ( ) Familiar
C. ( ) Arrendada
d. ( ) Parceria

5. Granja de postura é a principal atividade na propriedade?
a. ( ) Sim.
b. ( ) Não. Outra:

6. Sistema criação:
a. ( ) Gaiolas em bateria (tipo californiano).
b. ( ) Gaiolas enriquecidas (Bem estar).
c. ( ) Galpão/Piso.
d. ( ) Caipira/ Ar livre/Pasto

7. Linhagem:
a. ( ) Branca.
b. ( ) Vermelha.

8. Realiza Recria?
a. ( ) Sim.
b. ( )Não.

9. Realiza muda forçada ?
a. ( ) Sim
b. ( ) Não.

10. Fabrica a própria ração ? 

a.( ) Sim .
b.( ) Não. Compra no mercado.

11. Origem da água:

12. Qual o destino das aves mortas e de resíduos de ovos?
a.( ) Fossa
b.( ) Compostagem
c. ( ) Lixo
d.( ) Outros:

13. Comercialização dos ovos :
a.( ) Entreposto (SIM, SISP, SIF)
b.( ) Atacado
c. ( ) Varejo
d.( ) Industrialização
Quais municípios?

14. Localização da granja em relação ao centro consumidor/distribuidor:
a.( ) Até $5 \mathrm{Km}$
b.( ) 5 a $15 \mathrm{Km}$
c. ( ) 15 a $30 \mathrm{Km}$
d.( ) Acima de $30 \mathrm{Km}$

15. Como considera as vias de acesso para esse percurso:
a.( ) Muito bom (asfalto)
b.( ) Bom (misto asfalto e terra)
c.( ) Ruim (misto asfalto e terra cheia de buracos)
d.( ) Péssimo (terra com buracos e muita lama)

16. Possui Responsável Técnico (RT) ? ( ) Sim ( ) Não

17. Quantas pessoas desempenham a atividade avícola e respectivas remunerações (exceto $\mathrm{RT}$ ) ?
a.( ) 01
b.( ) 02
c. ( ) 03
d.( ) 04 ou mais

18. Idade do produtor.
a.( ) até 25 anos 

b.( ) 25 a 40 anos
c. ( ) 40 a 55 anos
d.( ) 55 a 70 anos
e.( ) acima de 70 anos

19. Sexo.
a.( ) Masculino
b.( ) Feminino

20. Qual (is) a (s) principal (is) fonte (s) de renda?
a.( ) Atividade avícola
b.( ) Atividades agropecuárias:
c.( ) Aposentadoria
d.( ) Outras:

21. Tempo na atividade:
a.( ) até 5 anos.
b.( ) 5 a 10 anos
c. ( ) 10 a 20 anos
d.( ) 20 a 30 anos
e.( ) acima de 30 anos

22. Porque o Sr. escolheu a atividade avícola ?
a.( ) Herança propriedade / instalações.
b.( ) Afinidade / Gosto
c. ( ) Outros:

23. Grau instrução:
a.( ) Não alfabetizado.
b.( ) Básico.
c. ( ) Fundamental.
d.( ) Médio.
e.( ) Superior.

24. Religião:
a.( ) Ateu
b.( ) Católico
c.( ) Evangélico
d.( ) Espiritualista 

e.( ) Outro:

25. Residência:

a.( ) Propriedade rural

b.( ) Cidade: ( ) Casa própria ( ) Alugada ( ) Outro

26. Veículo de passeio:
a.( ) Sim.
b.( ) Não.

27. Enumere em ordem decrescente o que pesa mais no seu custo de produção?
a.( ) Ração
b.( ) Aquisição pintainhas/frangas recriadas
c. ( ) Manutenção das instalações
d.( ) Veterinário
e.( ) Medicamentos
f. ( ) Outros:

28. Qual é o faturamento bruto mensal com a atividade?

29. Considera a atividade:
a.( ) Muito rentável
b.( ) Medianamente rentável
c. ( ) Pouco rentável
Justifique:

30. Possui Dívidas relacionadas a atividade?
a.( ) Não
b.( ) Sim. Valor:

31. Possui acesso à Internet?
a.( ) Sim.
b.( ) Não.

32. Acompanha informações sobre o mercado de ovo ?
a. ( ) Sim, Como: ( ) Internet ( ) Jornal/Revistas ( ) TV/Rádio ( ) RT/ Produtores b.( ) Não, Porque?

33. Acredita que se tivesse mais conhecimento, a atividade seria melhor e mais rentável?

$$
\text { a. ( ) Sim. }
$$


b. ( ) Não.

34. Gostaria de participar de palestras ou eventos ligados a avicultura?

a.( ) Sim.

b. ( ) Não.

35. O que o impede de conhecer mais sobre a atividade exercida ?
a.( ) Excesso de serviço
b.( ) Falta de interesse
c.( ) Desconhecimento das atividades
d.( ) Outros

36. O Sr pretende continuar na atividade avícola?

a.( ) Sim.

b.( ) Não. Porque?

37. Quais as suas perspectivas para a atividade?
a.( ) Excelentes / Otimista
b.( ) Boas
c. ( ) Ruins / Pessimitas
Justifique?

38. O Sr tem conhecimento das adequações necessárias para o registro do estabelecimento avícola comercial conforme determina as INs 56 , 59, 36 e $10 ?$
a.( ) Sim.
b. ( ) Não.

39. Quanto às adequações à Instrução Normativa:

a.( ) Estou adequando a granja e fica pronta até:

b.( ) Não vou me adequar. Farei parte da gestão de risco diferenciado. Justifique

40. Quanto o Sr acredita que vai gastar para adequar a granja às normativas?

41. Possui o dinheiro para realizar as adequações?
a.( ) Sim.
b.( ) Não.

42. Necessita de financiamento?
a.( ) Sim.
b.( ) Não.

43. Os custos para adequação das instalações em atendimento à IN 56 pode 
gerar algum impacto econômico e social para o produtor e sua família, uma vez que a não adequação impossibilita o registro e consequentemente a atividade?
a.( ) Sim.
b.( ) Não.
c. ( ) Fim da atividade.
Justifique:

44. Vai ser possível manter o preço de seu ovo após as adequações?
a.( ) Sim.
b.( ) Não.
Justifique:

\section{BEM ESTAR ANIMAL}

45. Como o Sr. enxerga suas aves?
a.( ) "Fábrica de ovos".
b.( ) Animais estimação.
c. ( ) Outro:

46. O Sr. se preocupa com o bem estar de suas poedeiras?
a.( ) Sim.
b.( ) Não.
Justifique:

47. O Sr. considera importante a questão do bem estar?
a.( ) Sim.
b.( ) Não.

48. O Sr. sabia que desde 2012 estão proibidos na Europa o uso de gaiolas em baterias para criação de aves de postura?
a.( ) Sim.
b.( ) Não.

49. O Sr adequaria a suas instalações de criação visando o bem estar em poedeiras, voluntariamente?
a.( ) Sim.
b.( ) Não.

50. O Sr. conhece outros sistemas de criação de galinhas poedeiras?
a.( ) Sim.
Qual: ( ) Piso.
( ) Gaiolas enriquecidas. ( ) Ar livre. 
b. ( ) Não.

51. Se houvesse uma lei proibindo a criação em sistema de gaiolas, qual seria o seu posicionamento?
a. ( ) A favor
b. ( ) Contra

Justifique: 